Portland State University

PDXScholar

1988

\title{
A geochemical study of the Eagle Creek Formation in the Columbia River Gorge, Oregon
}

\author{
Rachel Ann Carlin \\ Portland State University
}

Follow this and additional works at: https://pdxscholar.library.pdx.edu/open_access_etds

Part of the Geochemistry Commons, and the Geology Commons

Let us know how access to this document benefits you.

\section{Recommended Citation}

Carlin, Rachel Ann, "A geochemical study of the Eagle Creek Formation in the Columbia River Gorge, Oregon" (1988). Dissertations and Theses. Paper 3749.

https://doi.org/10.15760/etd.5633

This Thesis is brought to you for free and open access. It has been accepted for inclusion in Dissertations and Theses by an authorized administrator of PDXScholar. Please contact us if we can make this document more accessible: pdxscholar@pdx.edu. 
AN ABSTRACT OF THE THESIS OF Rache1 Ann Carlin for the Master of Science in Geology presented June 29, 1988.

Title: A Geochemical Study of the Eagle Creek Formation in the Columbia River Gorge, Oregon.

\section{APPROVED BY MEMBERS OF THE THESIS COMMITTEE:}

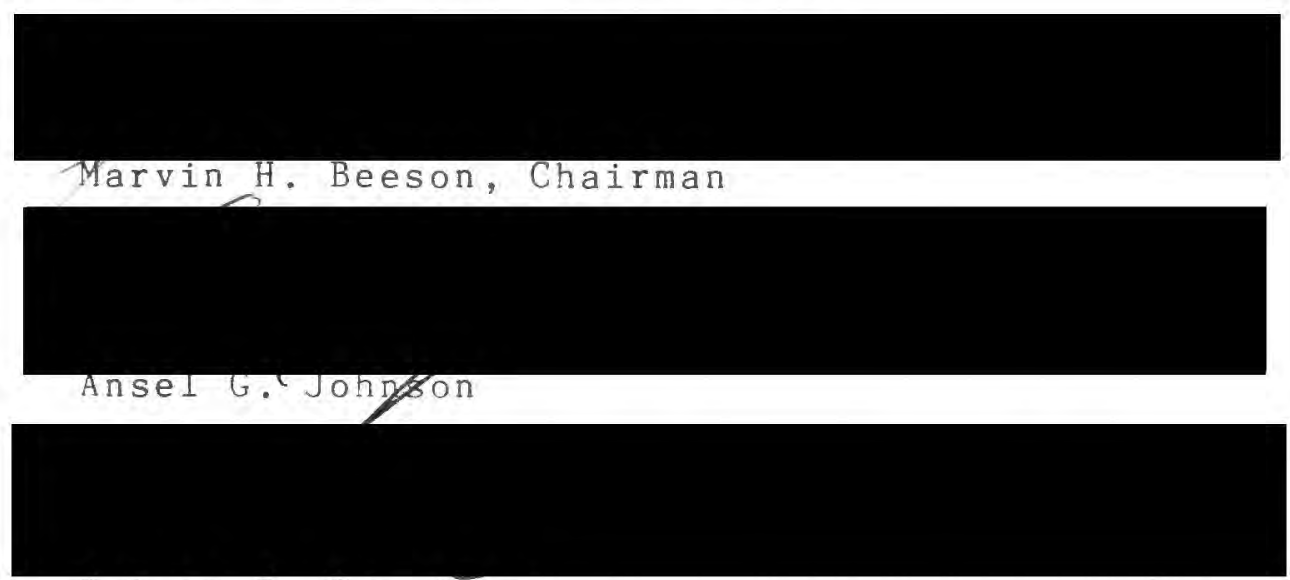

$$
\text { Robert } 0 \text {. Van Atta }
$$
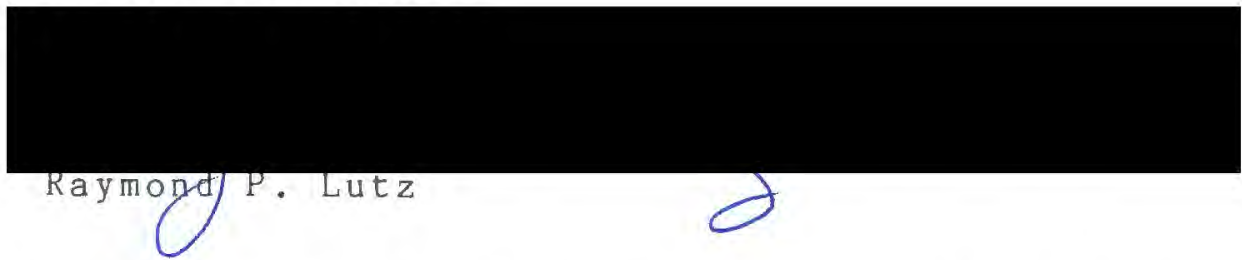

The Early Miocene Eagle Creek Formation, a series of volcanic mudflows and debris flows, is exposed in the Columbia River Gorge about 64 kilometers east of Portland, Oregon. Eighty-seven samples were analyzed using instrumental neutron activation analysis for trace element concentrations. Eleven samples were analyzed by Dr. Peter Hooper at Washington State University using $X-r a y$

Fluorescence for major element chemistry. These data were 
used to determine that the Eagle Creek Formation compositionally ranges from andesite to dacite.

Statistical analysis of the trace element chemistry showed that, at this point, no lateral correlations or chemical stratigraphy can be determined. However, the use of principal component analysis and cluster analysis was shown to be very efficient at separating individual mudflow units, thereby, making trace element fingerprinting useful especia1ly if field relationships are questionable.

A comparison of the Eagle Creek samples to known hydrotherma11y altered Eagle Creek Formation samples showed that, on the whole, the bulk compositions of the formation has not been changed even though secondary clay mineralization is common. Additionally, the Late Eocene-Early Miocene Skamania Volcanic Series was tested as a possible source for the Eagle Creek Formation. The differences in trace element concentrations and the published ages eliminate this possibility.

Finally, the Eagle Creek Formation was compared to other Miocene Western Cascade rocks. Chemically, all of these rocks follow trends which are probably attributable to andesitic volcanism and tectonic setting. A similar geochemical study of the thicker section of the Eagle Creek Formation on the Washington side of the Columbia River and also a study of the Clackamas River exposures might yet reveal a chemical stratigraphy of the Eagle Creek Formation. 
The northernmost exposures of the Oligo-Miocene Little Butte Volcanic Series should also be analyzed as a possible source of the Eagle Creek Formation. 
A GEOCHEMICAL STUdy OF THE EAgLE CREEK FORMATION IN THE COLUMBIA RIVER GORGE, OREGON

by

RACHEL ANN CARLIN

A thesis submitted in partial fulfillment of the requirements for the degree of

MASTER OF SCIENCE

in

GEOLOGY

Portland State University

1988 
TO THE OFFICE OF GRADUATE STUDIES:

The members of the Comittee approve the thesis of Rachel Ann Carlin presented June 29, 1988.
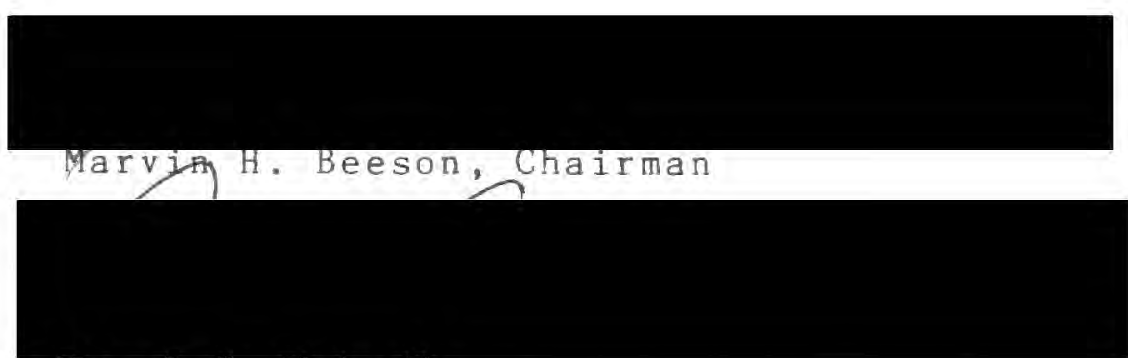

Ansel G. Johngon

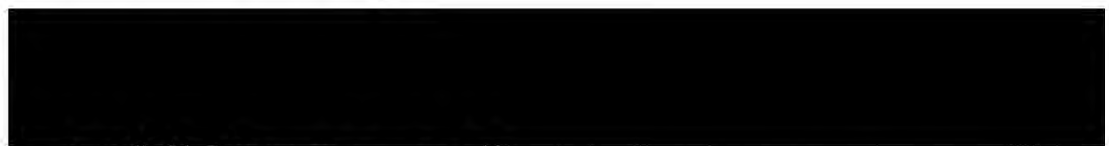

Robert 0 . Van Atta

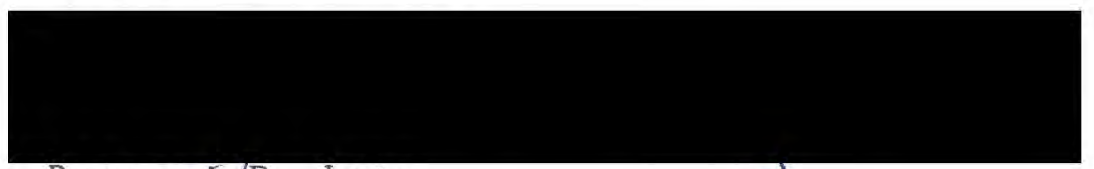

Raymond/P. Lutz

APPRAVED :

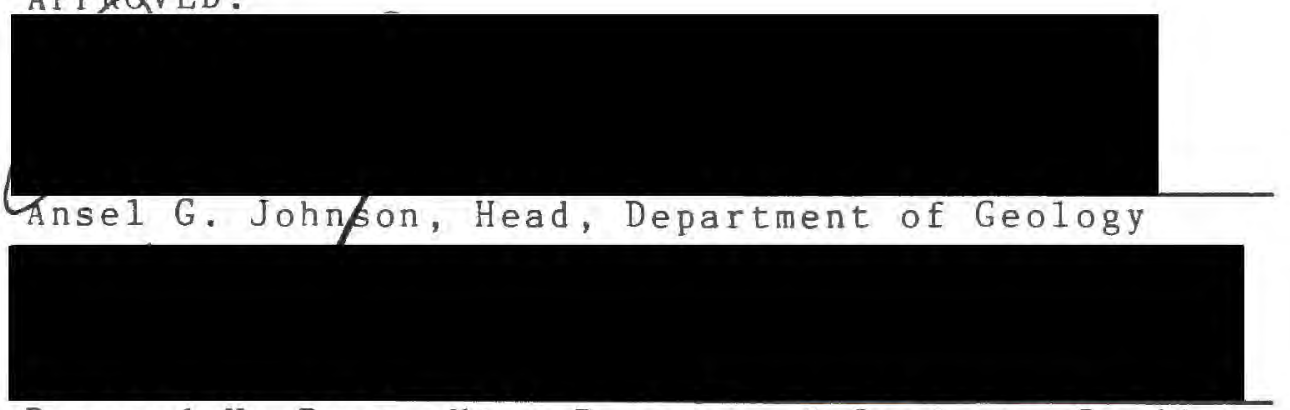

Bernard H. Ross, Vice Provost of Graduate Studies 


\section{ACKNOWLEDGEMENTS}

I would like to thank my committee for all of the helpful suggestions they offered to me. I would particular 1 y 1 ike to thank my advisor, Marv Beeson, for taking time to discuss problems and clear up confusion, listening to my presentations before I gave them publically, climbing ladders to collect samples for me, and helping me to meet my two-year goal. I would also like to thank Ansel Johnson without whom using computers would be like talking to alien life-forms. Bill Titus also suggested many ideas on sample collection methods and data manipulation which were used in this project.

Last (but definitely not least), I would like to thank my family and friends whose continued support enabled me to complete this part of my education. 
TABLE OF CONTENTS

PAGE

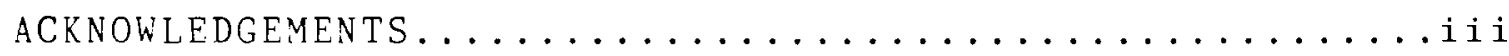

LIST OF TABLES $\ldots \ldots \ldots \ldots \ldots \ldots \ldots \ldots \ldots \ldots \ldots \ldots \ldots \ldots \ldots \ldots \ldots$

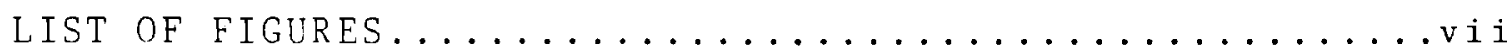

List OF Plates.......................

\section{CHAPTER}

I INTRODUCTION $\ldots \ldots \ldots \ldots \ldots \ldots \ldots \ldots \ldots \ldots \ldots \ldots \ldots \ldots \ldots$

Location of Study Area...............

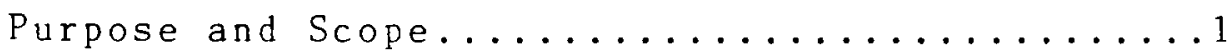

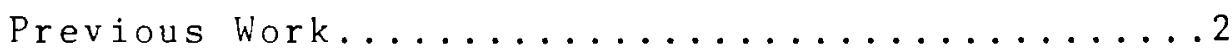

Geologic Setting...................

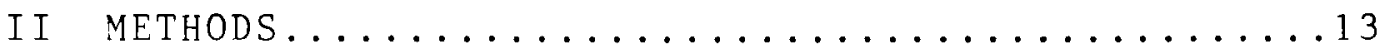

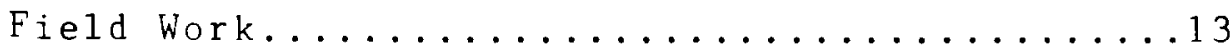

Analytical Procedure................ 16

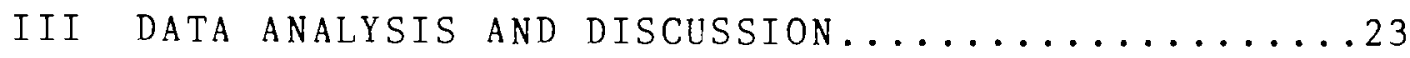

Paleomagnetic Survey............... 3

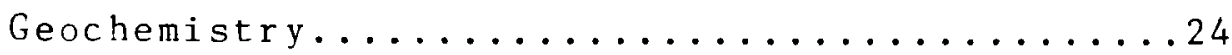

Statistical Analysis................... 33

Trace Element Fingerprinting...........41

Geochemica1 Stratigraphy.............46

Tectonic Analysis.................... 


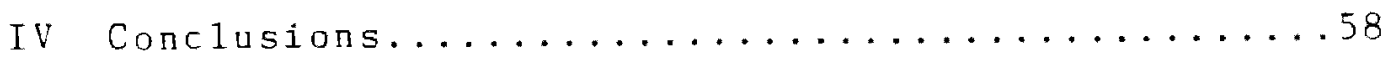

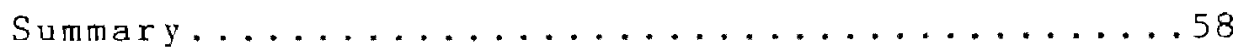

Recommendations for Further Study..........59

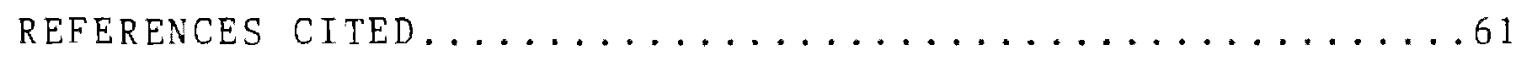

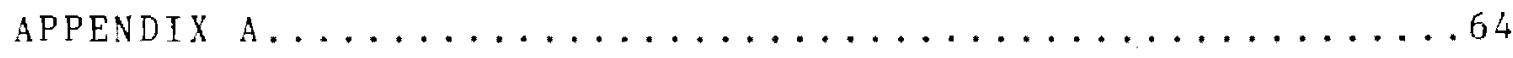

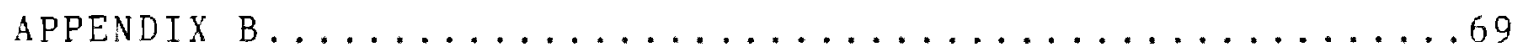

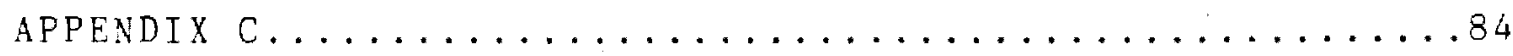

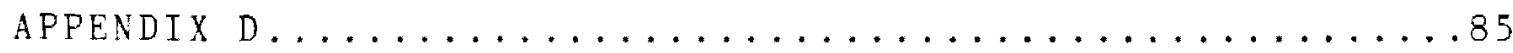

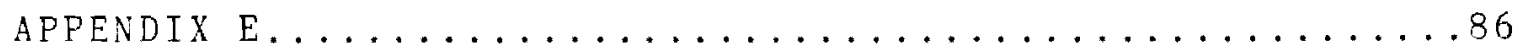

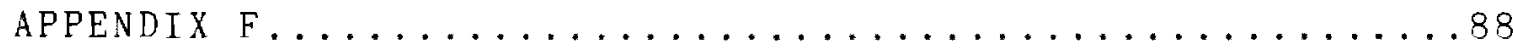




\section{LIST OF TABLES}

TABL,E

PAGE

I Average Trace Element Concentrations in

Fractions of the Eagle Creek Formation and

in the Skamania Volcanic Series........... 26

I Means and Standard Deviations of Elements in Samples MCC 25 and EC 15 and Samples RC 3

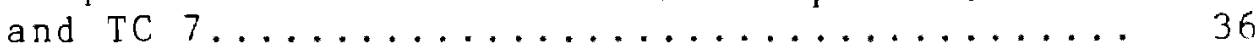

II Statistical Comparison of Variances and Means Between Samples MCC 25 and EC 15 and Samples RC 3 and TC $7 \ldots \ldots \ldots . \ldots \ldots$

IV Element Concentrations in the Three McCord

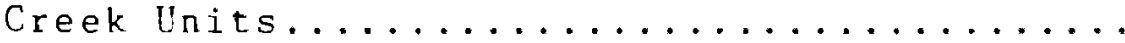




\section{LIST OF FIGURES}

\section{FIGURE}

1. Wise's (1961) Measured Section of Aldrich

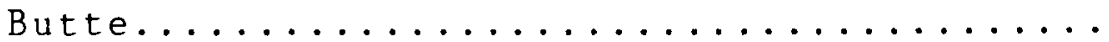

2. Generalized Map of Washington, Oregon, and northern California showing distribution of the Western Cascade, High Cascade, and Columbia River Basalt Groups............

3a. Generalized Stratigraphy of the Columbia

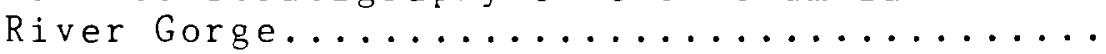

3b. Regional Correlations in Northern Oregon and

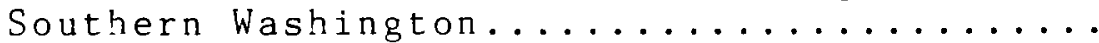

4. Stratigraphic Nomenclature, Age, and Magnetic

Polarity for the Columbia River Basalt

Group from Tolan and others (1984)........ 11

5. Pace and Compass Map of the Eagle Creek Trail... 14

6. Stratigraphic Position of Samples Collected

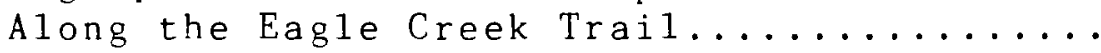

7. Sample Location Map for Skamania Volcanic

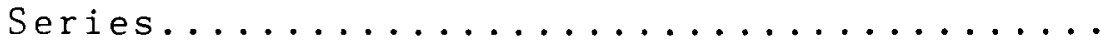

8. Outcrop on West Side of McCord Creek with

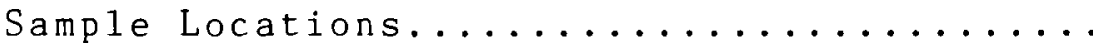

9. Outcrop on West Side of Eagle Creek at Exit

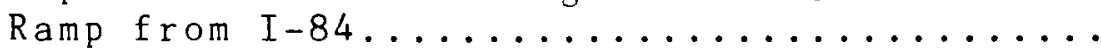

10. Location of Hydrothermally A1tered Samples..... 20

11. Sample Location on East Side of Eagle Creek....

12. Chemical Classification of Volcanic Rocks

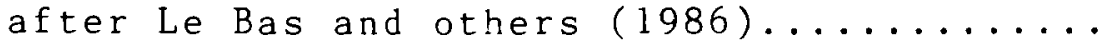

13. A Plot of Element Concentrations in Large Eagle Creek Formation Clasts and Skamania Volcanic Series................ 
14. Rare Earth Element Spider Diagram of Eagle

Creek Formation and Skamania Volcanic

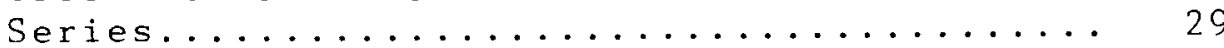

15. P1ot of $\mathrm{Na}_{2} \mathrm{O}(\mathrm{wt} \%)$ versus La (ppm)........... 31

16. Plot of $\mathrm{Cr}$ versus Co Showing Chemical Variation between Different Size Fractions..........

17. Tephra Layer at McCord Creek.............. 34

18. Eastern Part of Outcrop on the West Side of

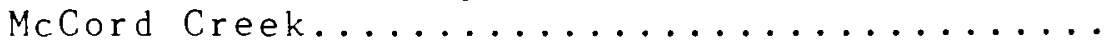

19. Western Part of Outcrop on the West Side of

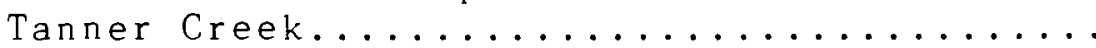

20. Dendrogram Showing Principal Component-

C1uster Ana1ysis Groupings..............

21. Western Part of Outcrop on the West Side of McCord Creek Showing Three Mudflow Units

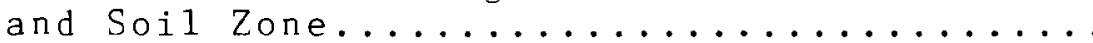

22. A and B: Trace Element Plots Which Show the

Distinctions between the Three Mudflow

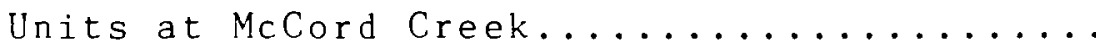

23. Dendrogram Showing Results of Principal

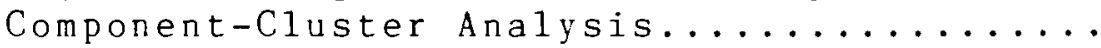

24. Dendrogram Using On1y Immobile Elements to

Produce a Geochemical Stratigraphy........

25. Plot of $\mathrm{TiO}_{2}$ versus $\mathrm{P}_{2} \mathrm{O}_{5} \ldots \ldots \ldots \ldots \ldots \ldots \ldots \ldots \ldots \ldots \ldots \ldots \ldots \ldots$

26. Same as Figure 25 with Additional Data....... 54

27. P1ot of La versus Th Showing Tectonic

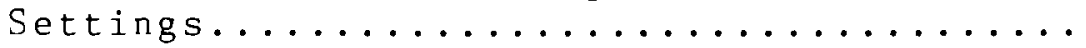




\section{LIST OF PLATES}

PLATE

PAGE

I. Geologic Map of the Bonneville Dam Area

IN POCKET 
CHAPTER I

INTRODUCTION

\section{LOCATION OF STUDY AREA}

The study area is located in Multnomah and Hood River Counties, Oregon, where the Columbia River Gorge provides exposure of the Early Miocene Eagle Creek Formation beneath the Columbia River Basalt Group. The area studied is roughly 6.5 square kilometers. Access to the nearly vertical outcrops is along Interstate Highway 84 , the Union Pacific Railroad, and in the McCord, Tanner, and Eagle Creek valleys (Plate I).

\section{PURPOSE AND SCOPE}

The main purpose of this study was to obtain quantitative data on the Eagle Creek Formation to aument earlier qualitative work. The primary questions to be answered are as follows:

1. What is the chemical rock type of the Eagle Creek Formation?

2. Is the Skamania Volcanic Series a source of the Eagle Creek Formation?

3. How much does alteration affect the trace element signatures?

4. How much chemical variablity is there in different 
size fractions?

5. Are there any lateral or vertical geochemical stratigraphic trends in the section?

6. Are individual mudflow units distinguishable from each other?

7. What was the tectonic setting of the Eagle Creek Formation and how does the formation compare to other Miocene andesitic volcanic rocks found in Oregon?

Methods used to answer these questions are:

1. Fie1d observation

2. Instrumenta 1 neutron activation analysis

3. X-ray fluorescence

4. Statistical analysis

5. Petrographic analysis

\section{PREVIOUS WORK}

Although fossil flora were collected from the Eagle Creek Formation as far back as 1871 by LeConte and somewhat later by Diller (Wi1liams, 1916), it was not until 1916 that it was named by I. Williams in his study of the Columbia River Gorge. Williams stated that LeConte dated the formation as Miocene based on the fossil flora. Williams (1916) specifically suggested that the Eagle Creek Formation was Late Miocene in age based on the fossils found by R.R. Chaney. However, Chaney (1918) later found 80 species of plants and suggested that the Eagle Creek Formation was "tentatively Upper Eocene because the flora assemblage resembled the fossils in the Upper Clarno beds of the John Day Basin..." The dominant species was an oak which was interpreted to represent an upland environment. The 
presence of maples, elms, and sycamores was interpreted to indicate valleys because the delicate leaves of these trees could not be transported very far. Chaney also suggested that the source of the Eagle Creek Formation was an E-W trending mountain range to the north.

Barnes and Butler (1930) included a section on the Eagle Creek Formation (their Warrendale Formation) in their work on the Columbia River Gorge. For the most part, their work was a 1 isting and rough description of every outcrop they could find. They described the formation as being composed of conglomerate with porphyritic andesite boulders. The presence of crystals of augite and plagioclase in the matrix enabled them to conclude that the Eagle Creek Formation was of volcanic origin.

A11en (1932) a1so listed every exposure of the Warrendale Formation. He also subdivided the formation into five types of deposits:

1. Dense fine-grained tuffs.

2. Coarse tuff breccia.

3. Crystal grit to fine-grained breccia.

4. Boulder conglomerate.

5. Tuff to fine tuff conglomerate.

Allen stated that type four was practically universal on the Oregon side of the Columbia River; and that type five was most commonly found on the Washington side of the river. He also suggested that the Eagle Creek Formation was Early 
Miocene in age because "there was apparently a comparatively sma11 time interval before the outpouring of the Columbia River Basa1ts." Additiona11y, he suggested a source for the Eagle Creek Formation to be 6.4 kilometers southeast of Big Huckleberry Ridge and/or perhaps Three-Cornered Rock.

Wise (1961) subdivided the Eagle Creek Formation into the Oligocene Weigle Formation and the Early Miocene Eagle Creek Formation based on a slight angular unconformity and the presence of a saprolite. He suggested that orthoconglomerates $(<30 \%$ matrix) were deposited by rapid water. Paraconglomerates ( $>30 \%$ matrix) were deposited by mudflows. Sandstones and fine conglomerates were deposited by streams with lower velocities and smaller loads than the orthoconglomerates. Tuffaceous sandstones were ashfal1 deposits; some were locally reworked. Wise also contributed a measured section of Aldrich Butte (Figure 1) located on the Washington side of the river just north of Bonneville Dam.

\section{GEOLOGIC SETTING}

The Columbia River Gorge provides a spectacular crosssection of the Cascade Range. To better understand the geologic history of the gorge, it is helpful to review the regional Cenozoic tectonic evolution of the northwestern United States. Igneous activity began in Washington, northern Idaho, and Montana about 55 Ma (Armstrong, 1978). 


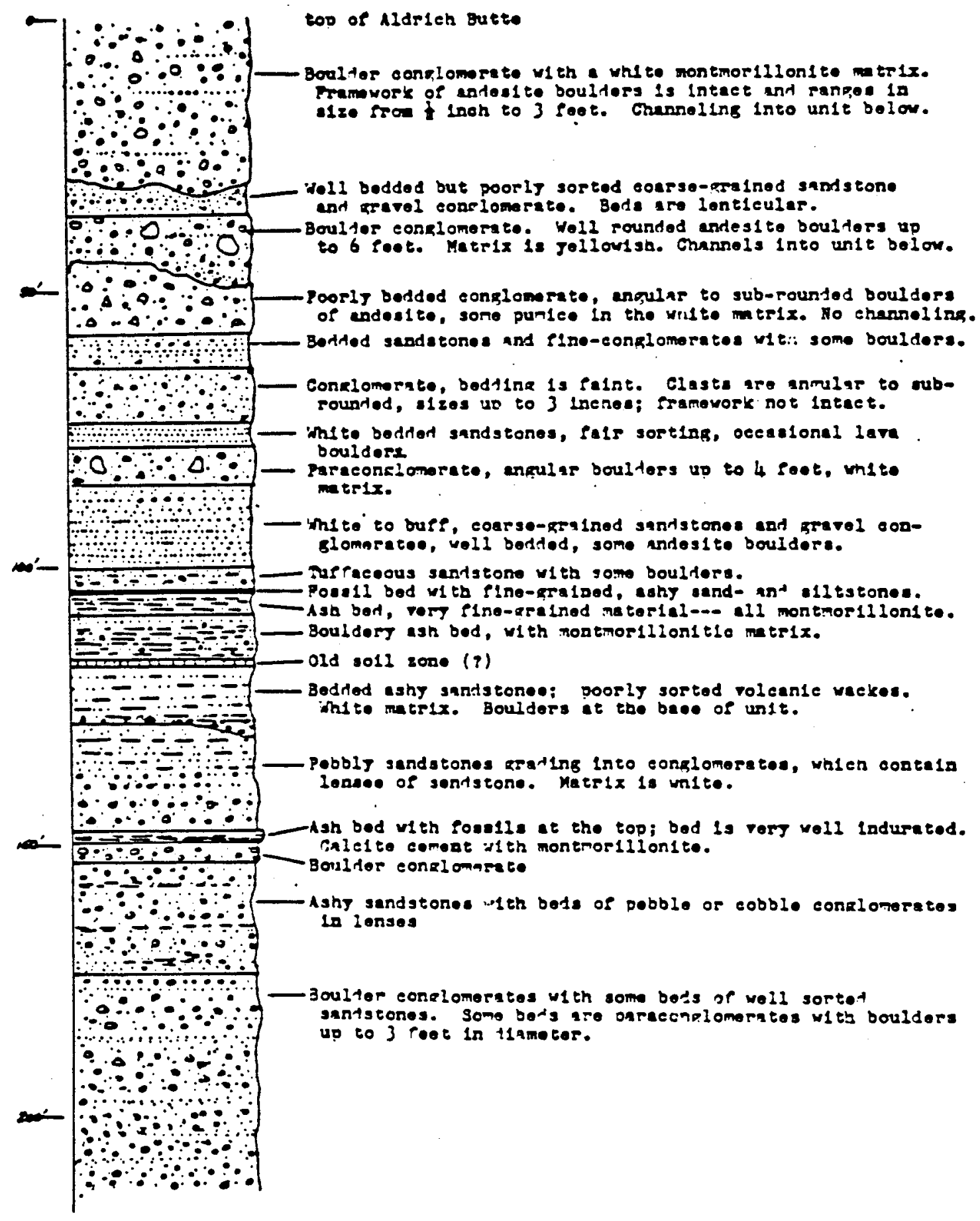

Figure 1. Wise's (1961) measured section of Aldrich Butte. See Plate I for location of Aldrich Butte in Washington across the Columbia River from the study area. 
The peak of volcanism occurred during the Challis episode in central Idaho and in the Absaroka arc in northwestern Wyoming and southwestern Montana 50-43 Ma (Armstrong, 1978). This basaltic volcanism (McBirney, 1978) in the east coincided with basaltic submarine eruptions of the coasts of Oregon and Washington (54-44 Ma). In the Portland area, the Waverly Heights basalt represents more Late Eocene subaerial basaltic volcanism which slightly predates the onset of calc-alkaline volcanism in the Western Cascades (Marvin Beeson, 1988, personal communication). The Clarno Formation of central Oregon correlates with the Challis-Absaroka arcs paleontologically and geochronometrically (Armstrong, 1978). After the Challis episode, igneous activity shifted southward to Nevada and Utah and westward to the Cascade arc (Armstrong, 1978). See Figure 2 for location of the Cascade arc. In the area of the Columbia River Gorge, the Skamania Volcanic Series (basalts, andesites, dacites, and volcaniclastic rocks) (Figure 3a) were erupted between the Late Eocene and Early Miocene epochs (Tolan, 1982). These rocks can be found extensively on the Washington side of the gorge and between Latourell Falls and Shepperd's Dell State Park on the Oregon side. During the fairly quiescent period from 38-18 Ma (Armstrong, 1978) volcanism became more and more calcalkaline (McBirney, 1978). It was toward the end of this period that the Eagle Creek Formation was deposited. 


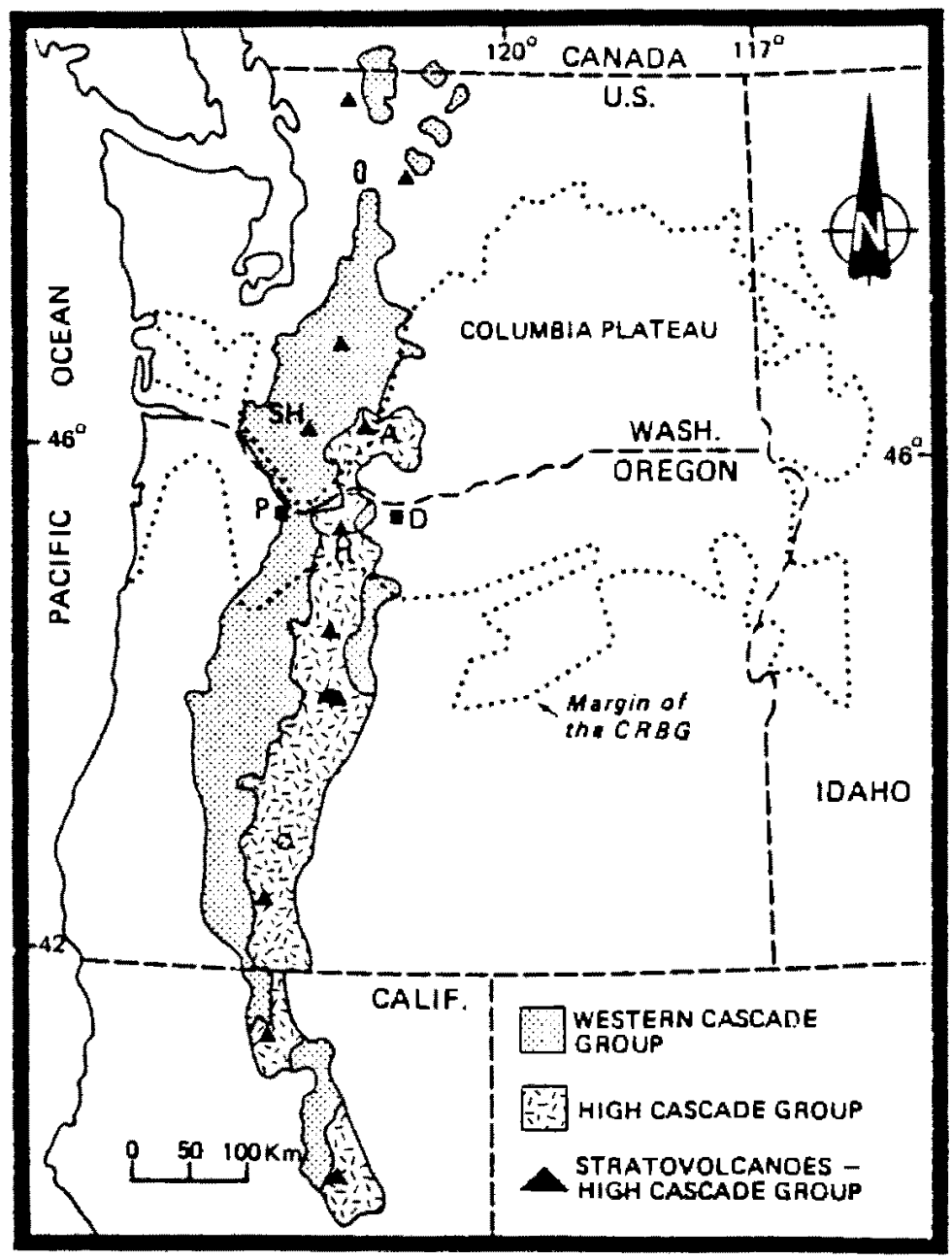

Figure 2. Generalized map of Washington, Oregon, and northern California showing distribution of the Western Cascade, High Cascade, and Columbia River Basalt Groups. P=Portland, $D=$ The Dalles, H=Mount Hood, SH=Mount St. Helens, $A=$ Mount Adams, CRBG=Columbia River Basalt Group. From Tolan and others (1984). 


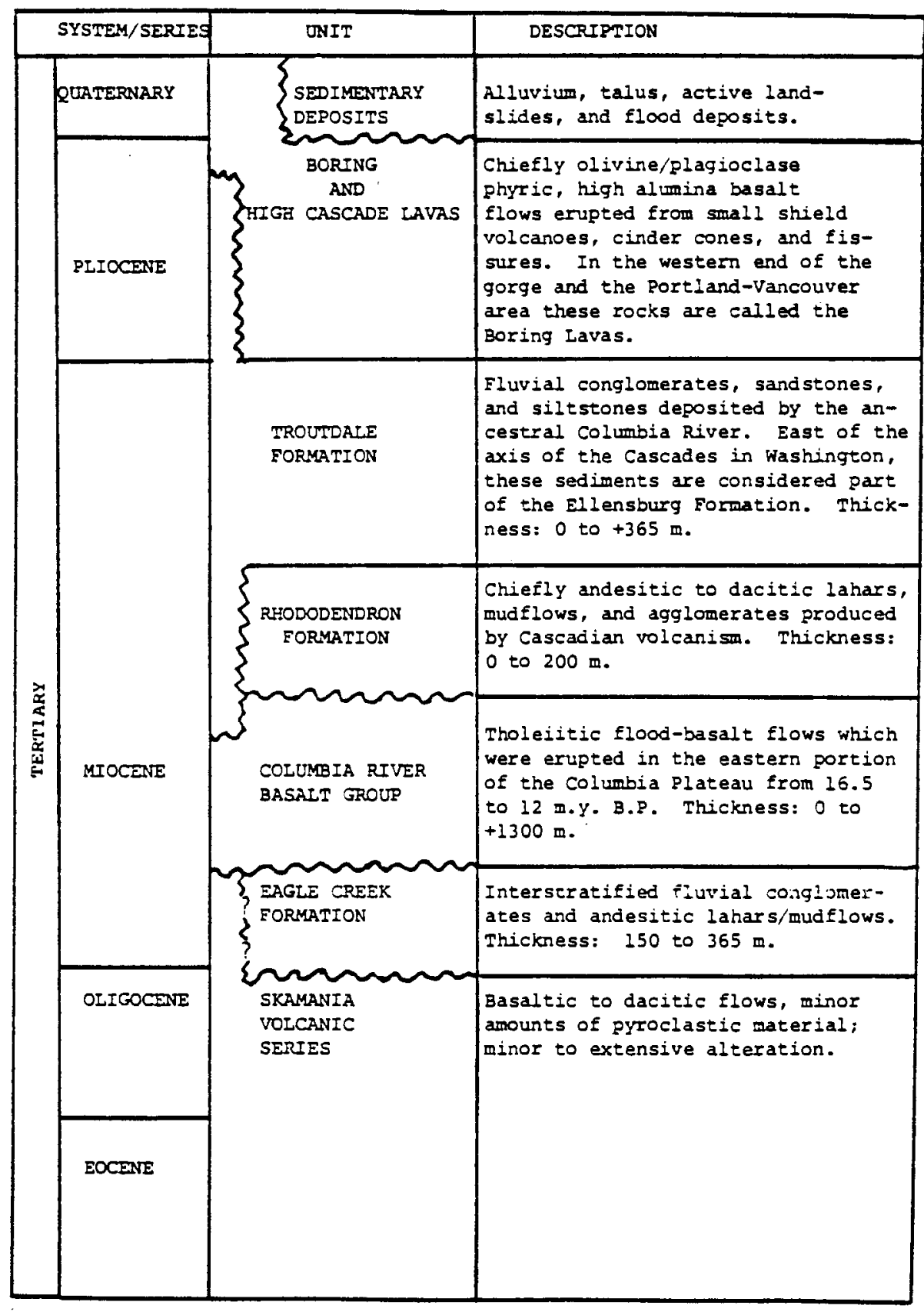

Figure 3a. Generalized stratigraphy of the columbia River Gorge. Modified from Tolan and others (1984). 


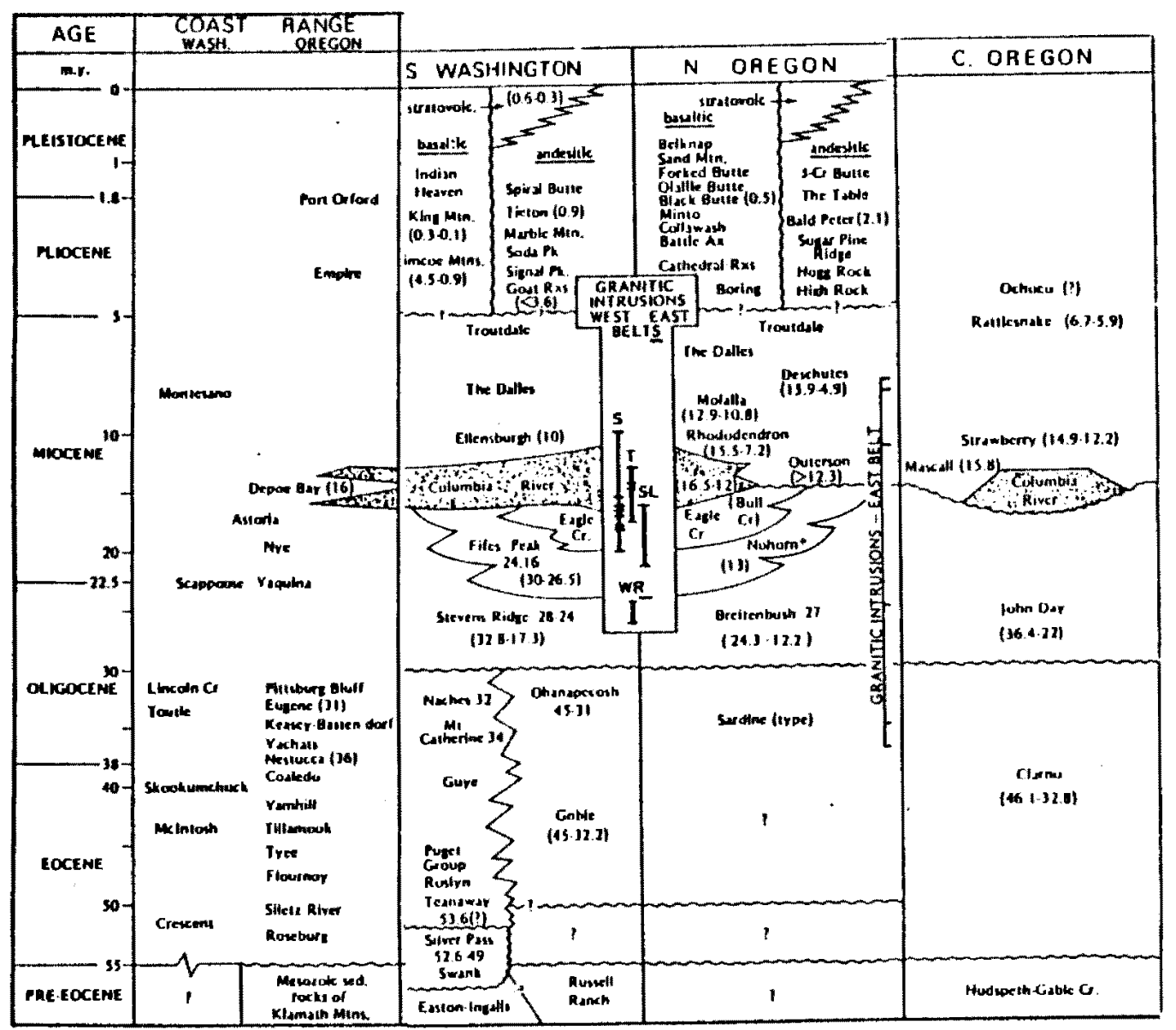

Figure 3b. Regional correlations in northern oregon and southern washington. Modified from Hammond (1979). Hammond's informal stratigraphic names represented by *. Numbers are age dates. Granitic intrusion names: $\mathrm{S}=$ Snolqualmie, $\mathrm{SL}=\mathrm{Sp}$ irit Lake, $\mathrm{T}=$ Tatoosh, WR=White River. 
Abruptly, eruption of the Columbia River Basalt Group (CRBG) from fissures or linear vents in northeastern Oregon, eastern Washington, and western Idaho (Tolan and others, 1984) began about $16.5 \mathrm{Ma}$ and continued until about $6 \mathrm{Ma}$. According to Mckee and others (1977), greater than 99\% of the volume of the CRBG was erupted during the first 3.5 million years (until $13.5 \mathrm{Ma}$ ). During this eruptive episode, a structural low in the Western Cascades near what is now the Oregon-Washington border allowed some of the CRBG to cross the Cascades and flow toward the Oregon coast (Armstrong, 1978). See Figure 2 for the distribution of the CRBG. The presence of the ancestral Columbia River can be inferred as far back as Frenchman Springs time (Figure 4) because of the intracanyon basalt flows which filled the river's channel (Tolan and others, 1984).

Interbedded with the CRBG on the west flank of Mt. Hood (Tolan and others, 1984) and overlying the basalts elsewhere is the Rhododendron Formation (andesitic to dacitic volcaniclastics and lava flows). The distal equivalent of the Middle Miocene Rhododendron Formation (Gannett, 1982) fills the NE trending Dalles and Mosier Synclines in the CRBG and is now called the Chenoweth Formation of the Dalles Group (Farooqui and others, 1981 ). Overlying the Rhododendron Formation in northern Oregon is the mid-Miocene-Pliocene Troutdale Formation. This formation consists of two facies of fluvial siltstones, 


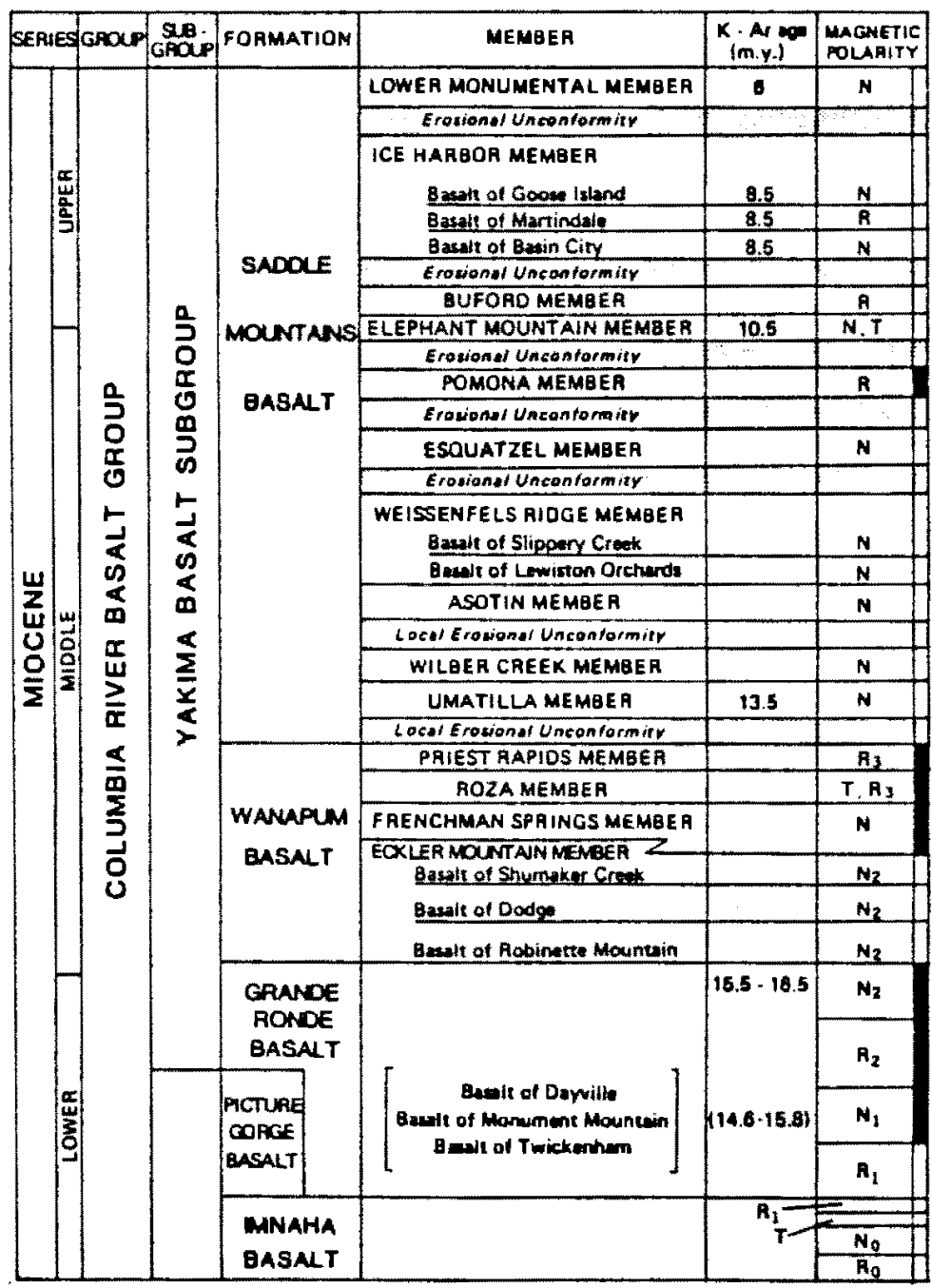

Figure 4. Stratigraphic nomenclature, age, and magnetic polarity for the Columbia River Basalt Group from Tolan and others (1984). N=normal magnetic polarity, $R=$ reversed magnetic polarity, $\mathrm{T}=\mathrm{transitional}$ magnetic polarity, m.y.=million years. Black bar in right-hand column indicates units known to be present in the Columbia River Gorge region. 
sandstones, and conglomerates. The Columbia River facies. can be distinguished from the Cascadian stream facies by the presence of quartzite, schist, granite, and rhyolite clasts with no local source (Tolan and others, 1984).

The culminating activity of the Cascade Range from the Pliocene to the present was the eruption of small basaltic shield volcanoes, the upwarping of the range (Allen, 1979), and the development of the High Cascades. See Figure 2 for locations of the most recently active High Cascade stratovolcanoes. See Figure $3 b$ for regional correlations in northern Oregon. 
CHAPTER I I

METHODS

FIELD WORK

Field work was done over a period of five months beginning in June, 1987. Almost all outcrops were found either in roadcuts along Interstate 84 or along the Elowah Falls, Tanner Creek, and Eagle Creek trails. Additional outcrop was found along the railroad cut below I-84 between Tanner Creek and Moffett Creek.

Because all of the outcrops are cliffs, all measured sections have been scaled from photographs (Appendix F). Using a fluxgate magnetometer, magnetic orientations of the Columbia River Basalt Group (CRBG) were taken as near as possible to the Eagle Creek Formation/CRBG contact. Three sampling methods were used:

1. In areas of minimal exposure, samples were collected where possible.

2. In the roadcuts where sections were measured, samples were taken from each major unit.

3. Along Eagle Creek, a pace and compass map of the trail was made (Figure 5). To obtain a vertical sequence in the type section, an attempt was made to collect samples every three to six meters using an altimeter (Figure 6).

Additionally, samples of the Skamania Volcanic Series were collected from the outcrops Tolan (1982) found to be most 


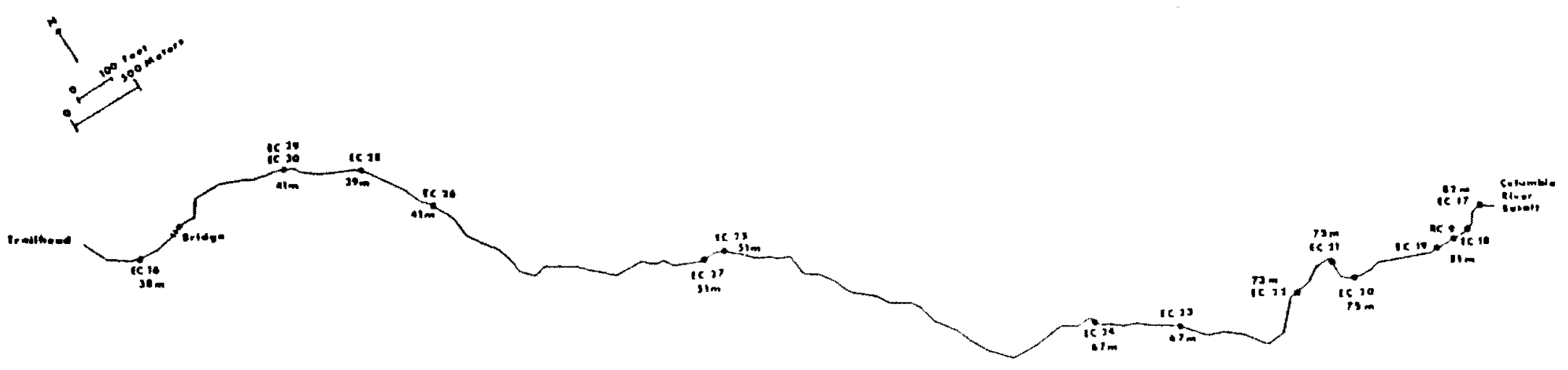

Figure 5. Pace and compass map of the Eagle Creek

Trail. Sample locations and elevations are in-

cluded. See plate I for location of trail. 


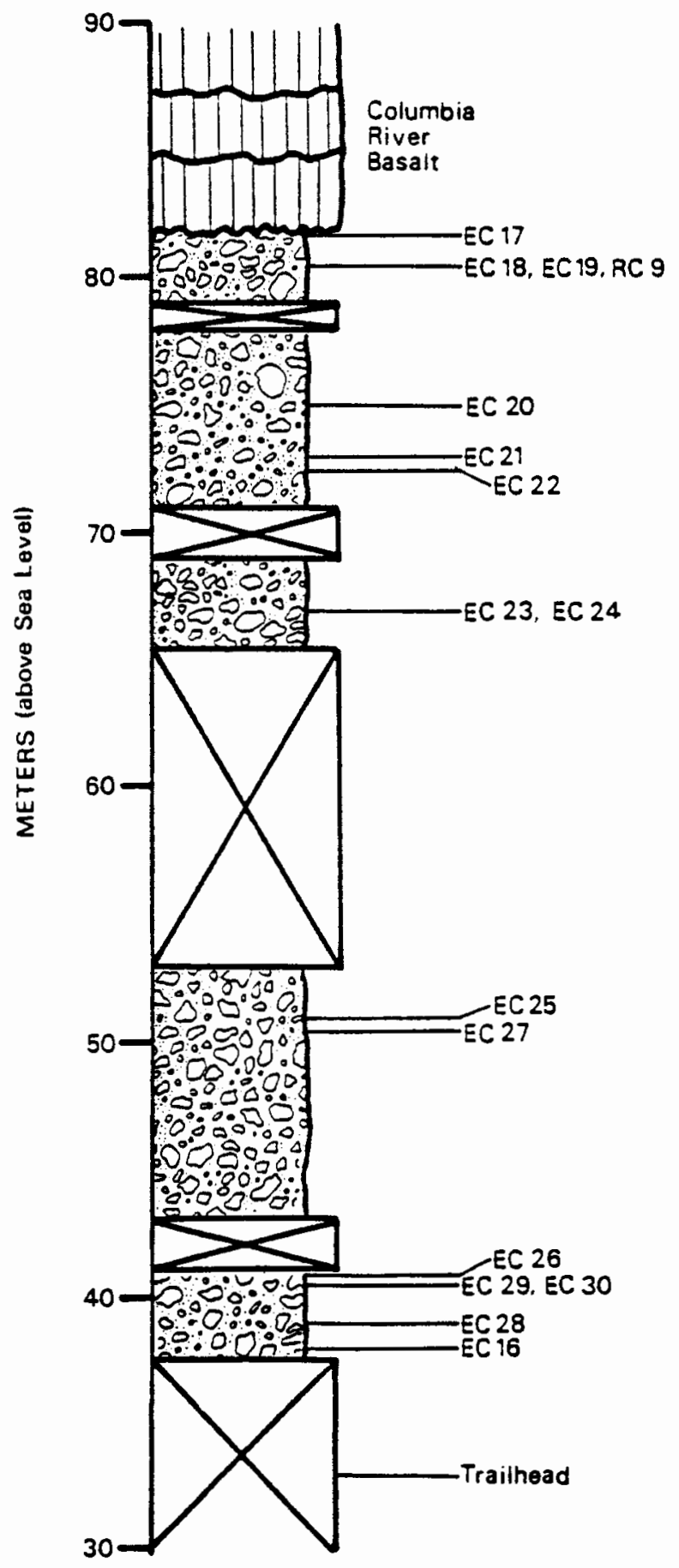

Figure 6. Stratigraphic position of samples collected along the Eagle Creek Trail. X's represent covered areas. 
silicic (Figure 7), and therefore, a more likely source for volcanic mudflows.

Approximate sample locations are marked on Plate I. Specific locations are labelled on photographs of the outcrops (Figures $8,9,10,11$ ). Appendix A contains handsample descriptions of these samples.

\section{ANALYTICAL PROCEDURE}

Eighty-seven samples were analyzed using instrumental neutron activation analysis (INAA). Thirty-seven of these samples are replicates (repeated samples taken from the same outcrop). These are indicated in Appendix B by a letter after the sample number. Five to ten replicates of some samples were analyzed to provide a statistical base. All whole rock sample aliquots ( 16 grams) were crushed to a maximum of $0.701 \mathrm{~mm}$. One sample (RC 7) was first sieved into four size fractions: very fine sand (0.061-0.208 mm), fine to medium sand $(0.208-0.589 \mathrm{~mm})$, coarse to very coarse sand $(0.589-1.981 \mathrm{~mm})$, and small to medium pebble gravel (greater than $3.962 \mathrm{~mm}$ ). This sample was easily sieved because of poor induration. However, to obtain a clean pebble-sized sample, ultrasound was used to disaggregate the surrounding smaller sized grains. The larger fractions from this sample were also crushed to $0.701 \mathrm{~mm}$ or less. Sample splits of about one gram were placed in clean $2 / 5$ dram polyvials and heat sealed to prevent leakage. More 


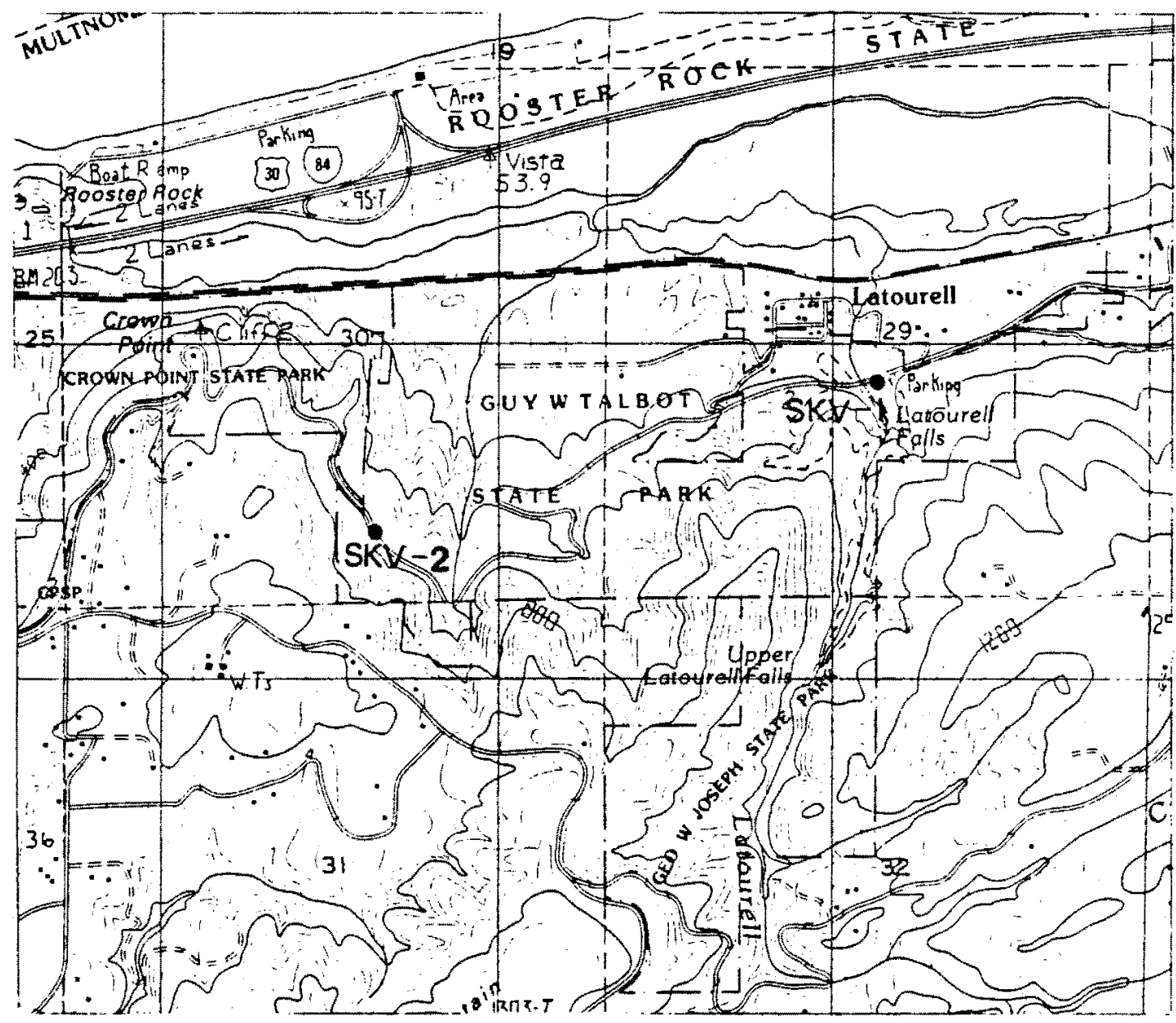

争

BRIDAL VEIL, OREG. - WASH.

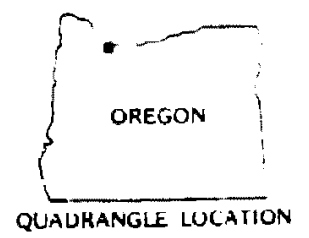

SCALE 1:24 000

$1000=\frac{5}{0}=\frac{1}{2000}$

CONTOUR INTERVAL 40 FEET

Figure 7. Sample location map for Skamania Volcanic Series. Latourell Falls is approximately 24 kilometers west of the westernmost exposure of the Eagle Creek Formation. 


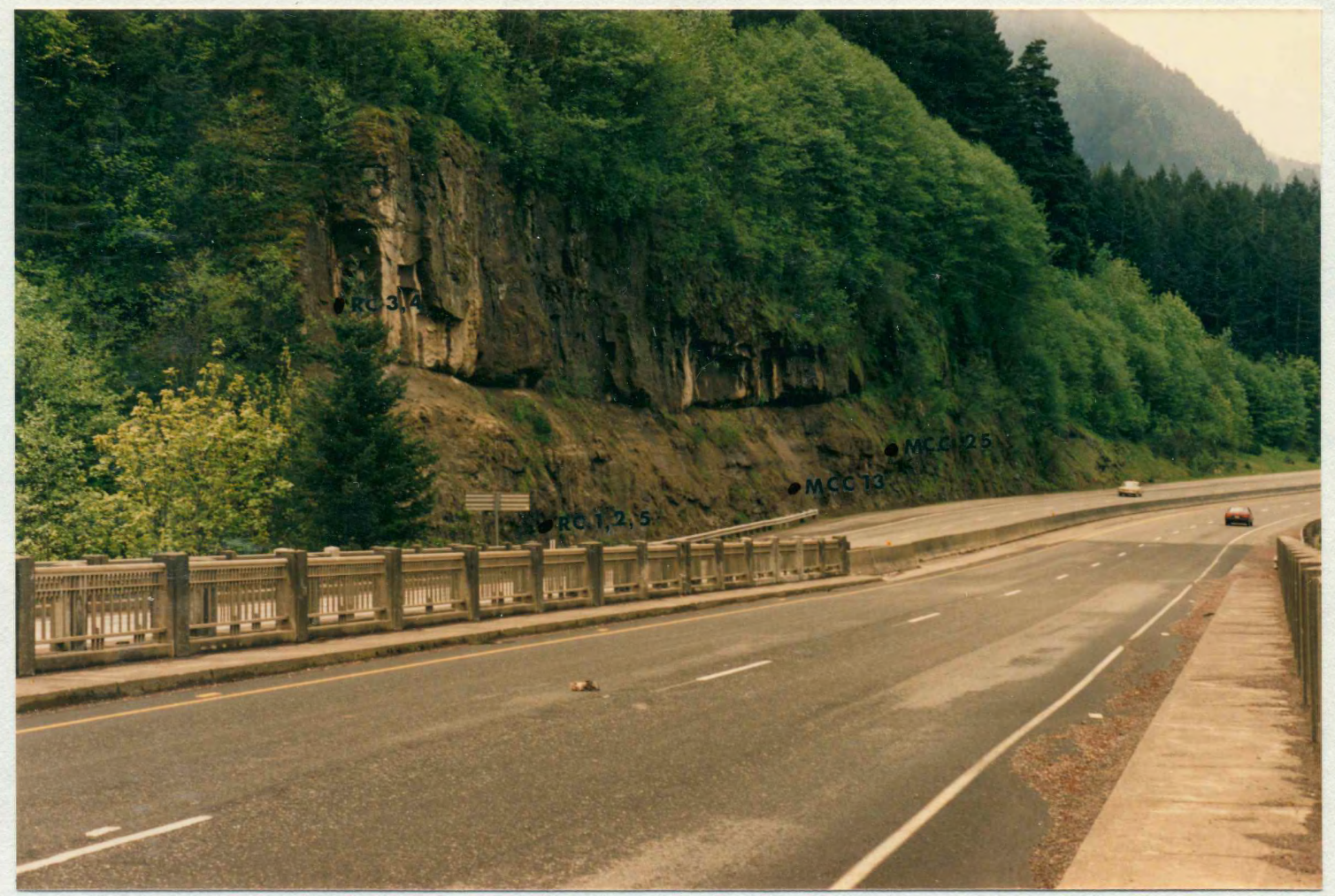

Figure 8. Outcrop on west side of McCord Creek with sample locations. Also note soil zone between two lower and one upper mudflow units. 


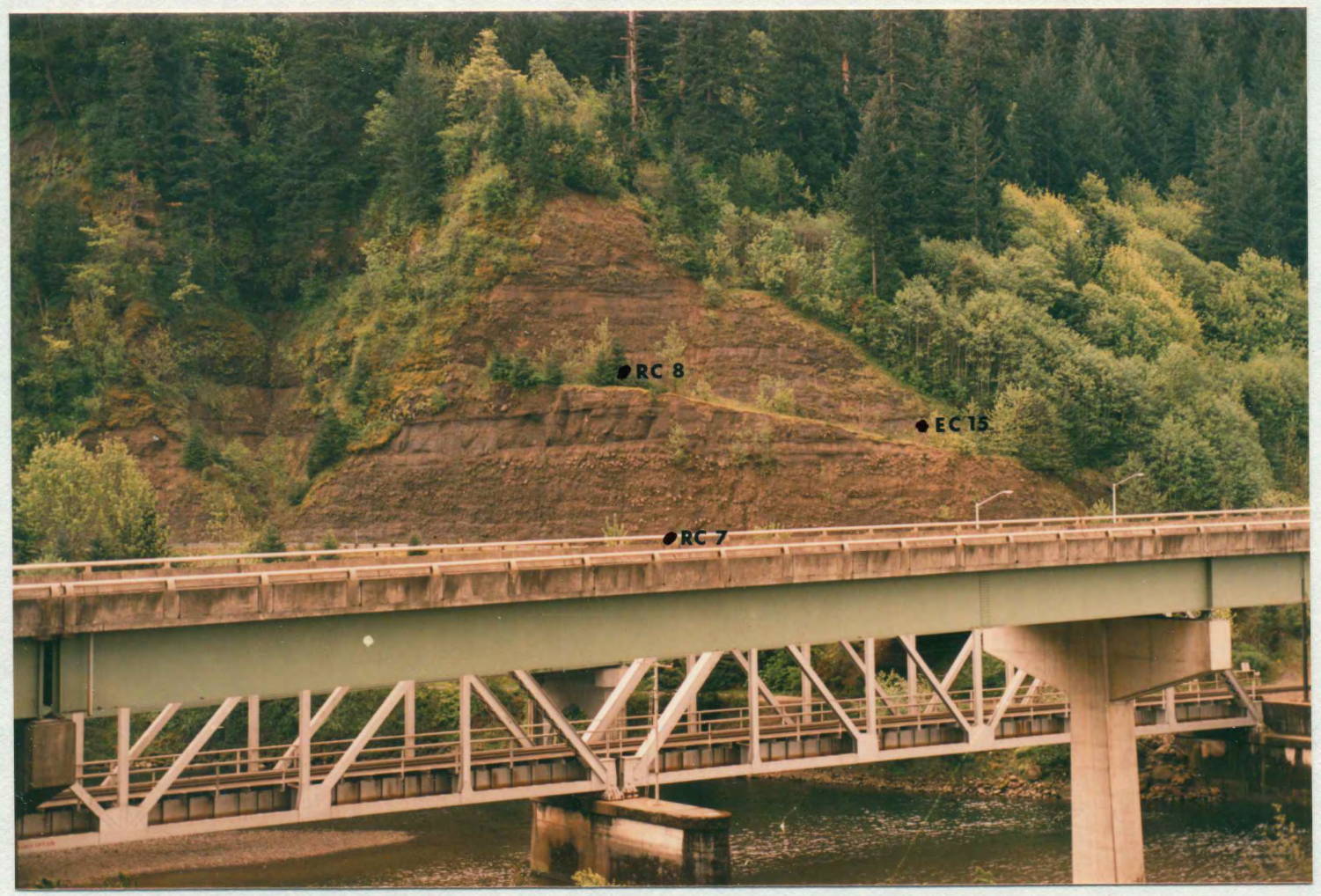

Figure 9. Outcrop on west side of Eagle Creek at exit ramp from I-84. Photograph shows sample locations. The very thin, whitish strata are interpreted to be tephra layers because of grain size, pumice fragments, and abundance of excellently preserved leaves and tree bark. 


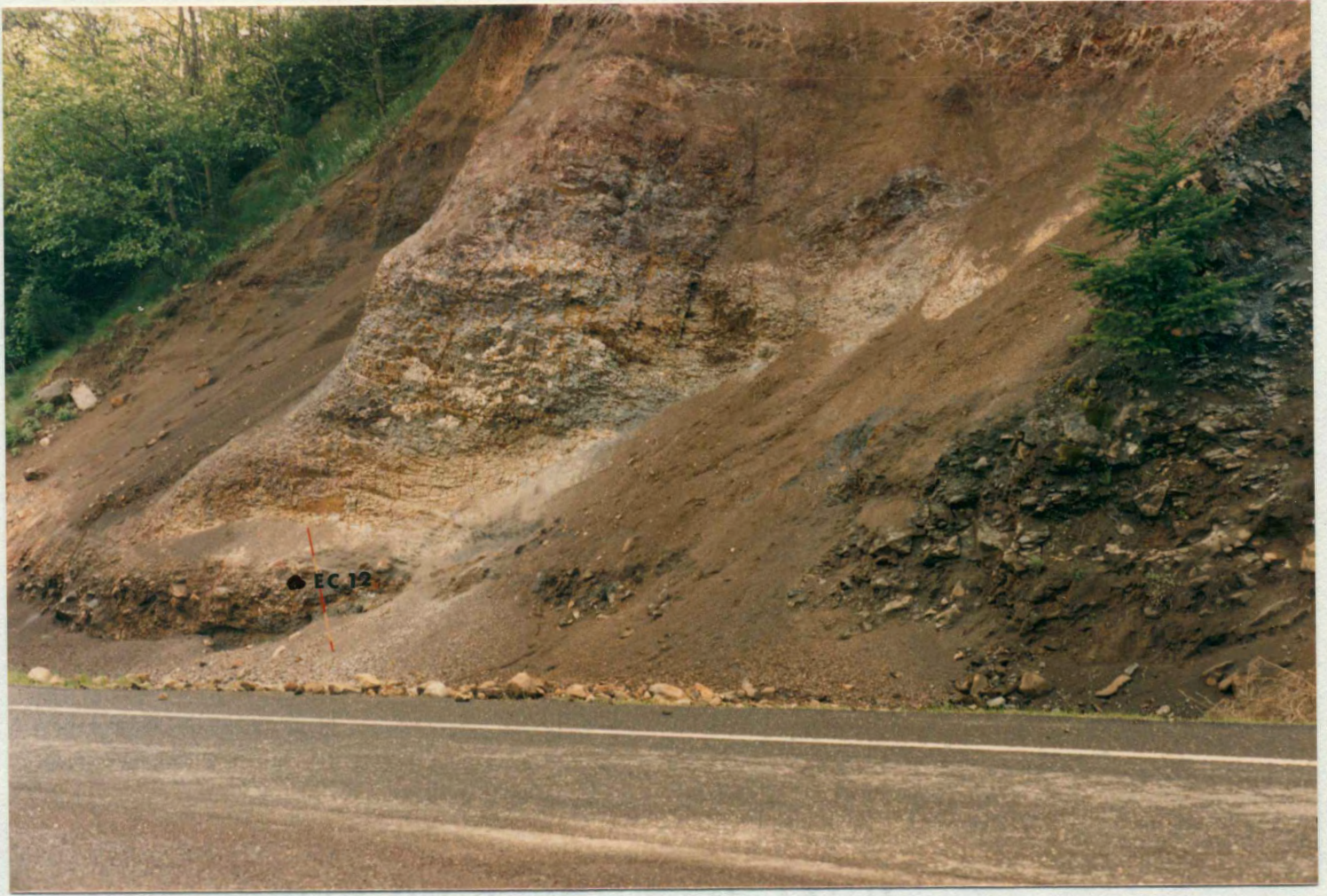

Figure 10. Location of hydrothermally altered samples. Intrusion is on right; altered Eagle Creek Formation is on left. Pebble and cobble conglomerate texture is preserved. Outcrop is about 122 meters east of Figure 9. 


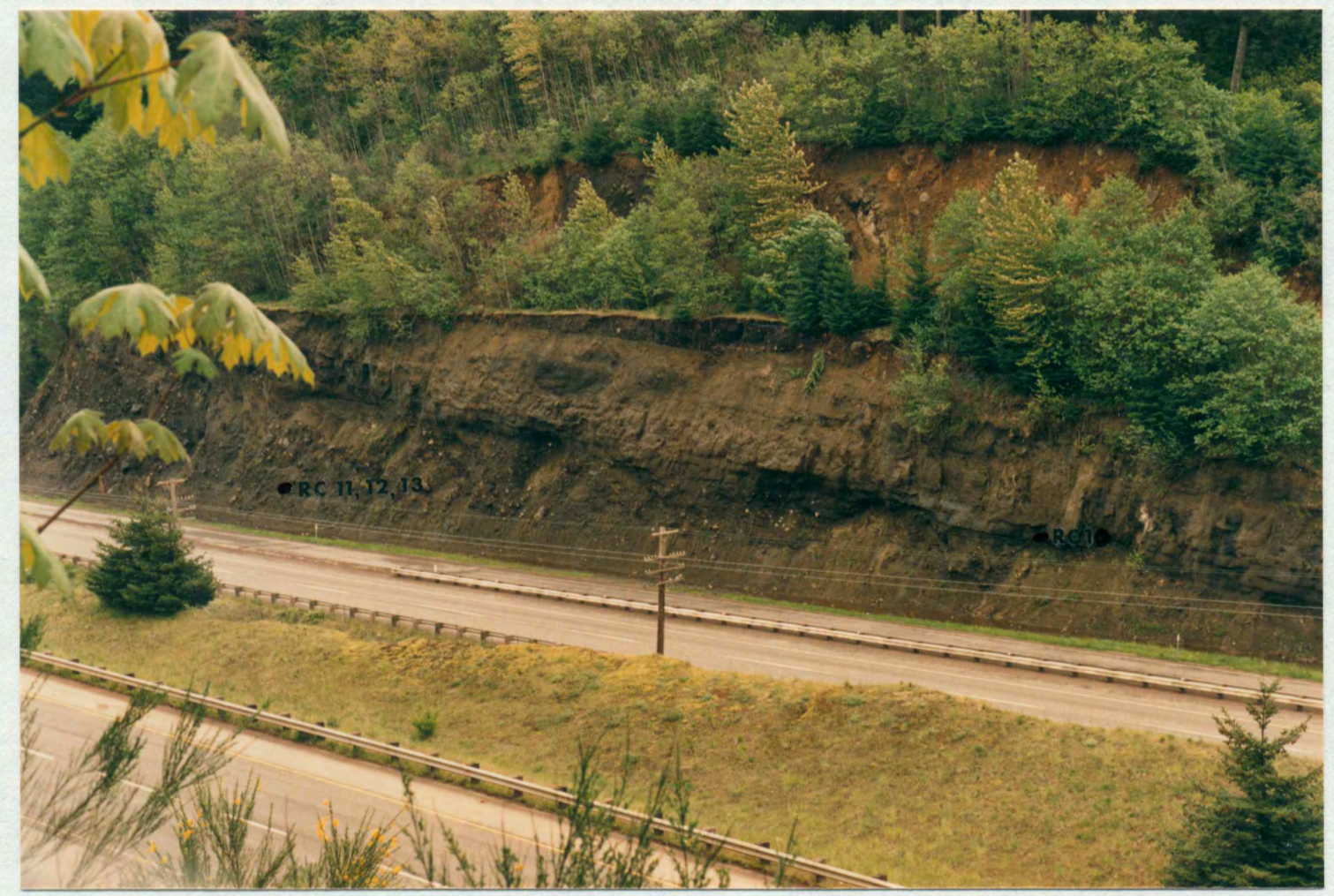

Figure 11. Sample location on east side of Eagle Creek. Large clast samples (RC 11-13) taken from unstratified lower unit which contains many petrified tree fragments and large sandstone rip-up clasts. Bedded unit is inversely graded and contains conglomerate lenses near top of cliff. Cliff above bench is part of the Ruckel Landslide. 
emphasis was placed on obtaining similar sample volumes than insuring a one gram mass. The samples were irradiated at $250 \mathrm{~kW}$ for one hour at the Oregon State University TRIGA reactor. Gamma ray spectra were first obtained by counting five days after irradiation. A second count was done 18-22 days after irradiation. Elemental abundances and errors were calculated by comparison to U.S.G.S. standards AGV-1, GSP-1, and to Portland State University standard 0-16. U.S.G.S. standard element concentrations were obtained from Flanagan (1976); PSU standard element concentrations were obtained from Gordon and others (1968).

After element concentrations were calculated, selected samples and replicates were sent to Dr. Peter Hooper at Washington State University for major element analysis using $X$-ray fluorescence (XRF). Additionally, a thin section was made of each sample that was analyzed by XRF and then described using a petrographic microscope. 


\section{DATA ANALYSIS AND DISCUSSION}

\section{PALEOMAGNETIC SURVEY}

The paleomagnetic orientation of the Columbia River Basalt Group flows was measured at three places using a fluxgate magnetometer. At Eagle Creek and Tanner Creek, the measurements were taken just above the Eagle Creek Formation/CRBG contact. At McCord Creek, no basalt was found in situ near the contact which is near the base of Elowah Falls. Therefore, the measurements were taken about 91 meters above the contact at the base of the third CRBG flow above the top of Elowah Falls.

At each location, the paleomagnetic orientation of four samples was measured to insure consistant results. At Eagle Creek, all samples recorded normal magnetic polarities. At Tanner and McCord Creeks, all samples recorded reversed magnetic polarities. According to Marvin Beeson (personal communication), the normal samples probably belong to the $\mathrm{N}_{1}$ magnetic polarity and the reversed samples belong to the $R_{2}$ magnetic polarity in the Grande Ronde Basalt (see Figure 4).

This survey indicates that at the time of the deposition of the CRBG there was some surface relief on the 
Eagle Creek Formation. Also, to the south, more of the lower parts of the CRBG are exposed. Since the survey at Eagle Creek was done about 1.5 kilometers farther south than at the other creeks, the differences in polarity are expected.

\section{GEOCHEMISTRY}

To characterize the Eagle Creek Formation in terms of chemical rock type, major element analysis was done on 11 samples (See Appendix B). The whole rock silica content in these samples ranges from about 60-68 weight percent. On the chemical classification diagram of volcanic rocks (Figure 12), the bulk composition of the Eagle Creek Formation ranges from andesite to dacite. Many of the clasts in the formation are andesite. Therefore, one wonders why there is such a wide range in silica content. The explanation of this observation might stem from the nature of the Eagle Creek deposits. Mudflows contain many large clasts. Associated with these clasts is a large volume of matrix material which must be derived from the more explosive, higher silica tephras produced in a volcanic eruption. Thus, the range in chemical composition is not unexpected.

For generalization, Table I contains the averages of 19 trace elements detected in the Eagle Creek Formation and in the Skamania Volcanic Series. Of special importance here 


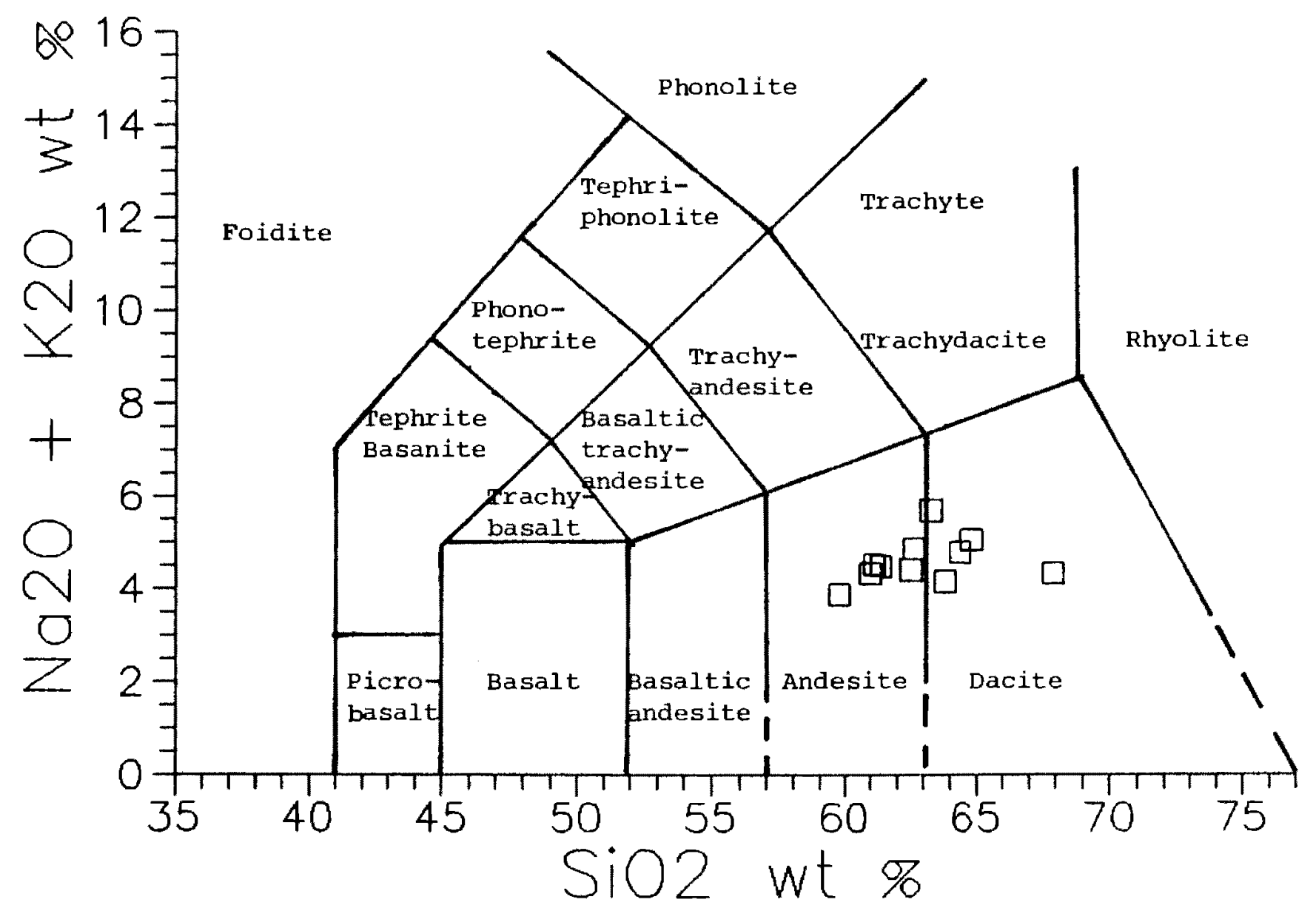

Figure 12. Chemical classification of volcanic rocks after Le Bas and others (1986). Diagram shows that the 11 Eagle Creek samples range from andesite to dacite. 
TABLE I

G.EFAGE TFACE ELEMEHI COHCENTKATIONS

In FHETIUHS OF THE EAGLE CKEEK FOGḾriIOH

ANII IN THE SKAMANÍ VOLCANIC SEFIES

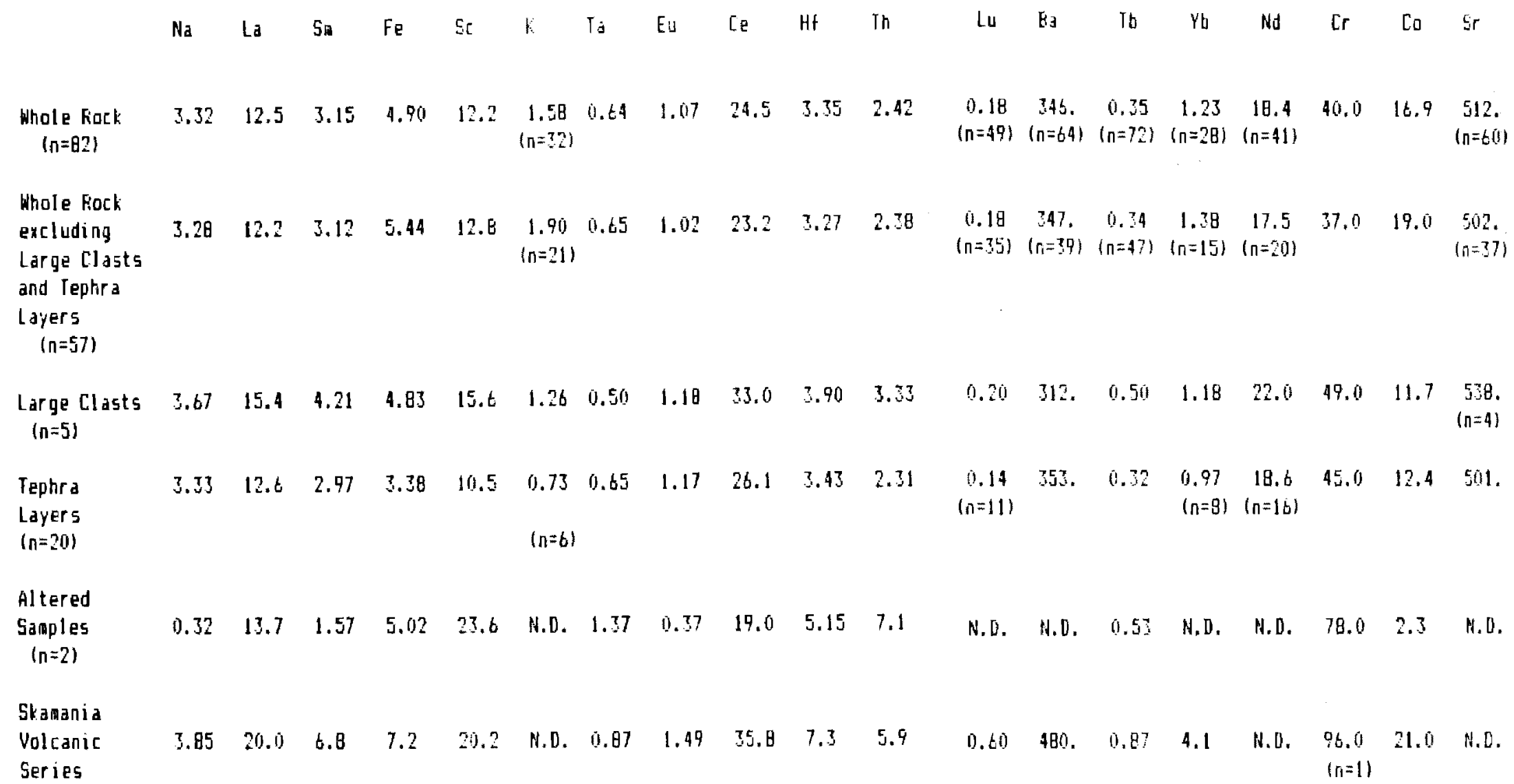


is the comparison between these two units. Since the Skamania Volcanic Series samples are an andesite and a dacite, it seemed logical to compare these samples only to the large clast samples in the Eagle Creek Formation to test whether the Skamania volcanoes could have been a sourcefor the Eagle Creek mudflows. Figure 13 shows the trace element concentrations in these samples normalized to the Eagle Creek whole rock averages for reference. While some elements in both the clasts and the Skamania volcanics show similar enrichment and depletion patterns, there are significant differences between the two units as a whole. Also, the Eagle Creek clast concentrations are closer to the Eagle Creek whole rock concentrations than the Skamania Volcanic Series values.

Additionally, when one compares only the rare earth elements normalized to the U.S.G.S. standard AGV-1 (Figure 14), one observes a strongly negative Eu anomaly in the Skamania Volcanic Series whereas both the Eagle Creek Formation whole rock and large clast samples have a slightly positive anomaly.

The published age of the Skamania Volcanic Series is 26.6-28.1 Ma (Phillips and others, 1986). The Eagle Creek Formation is probably quite a bit younger than this age range. A reason for this suggestion is that the preservation of 396 meters of mudflows requires either rapid subsidence or burial or both. It was mentioned earlier that 


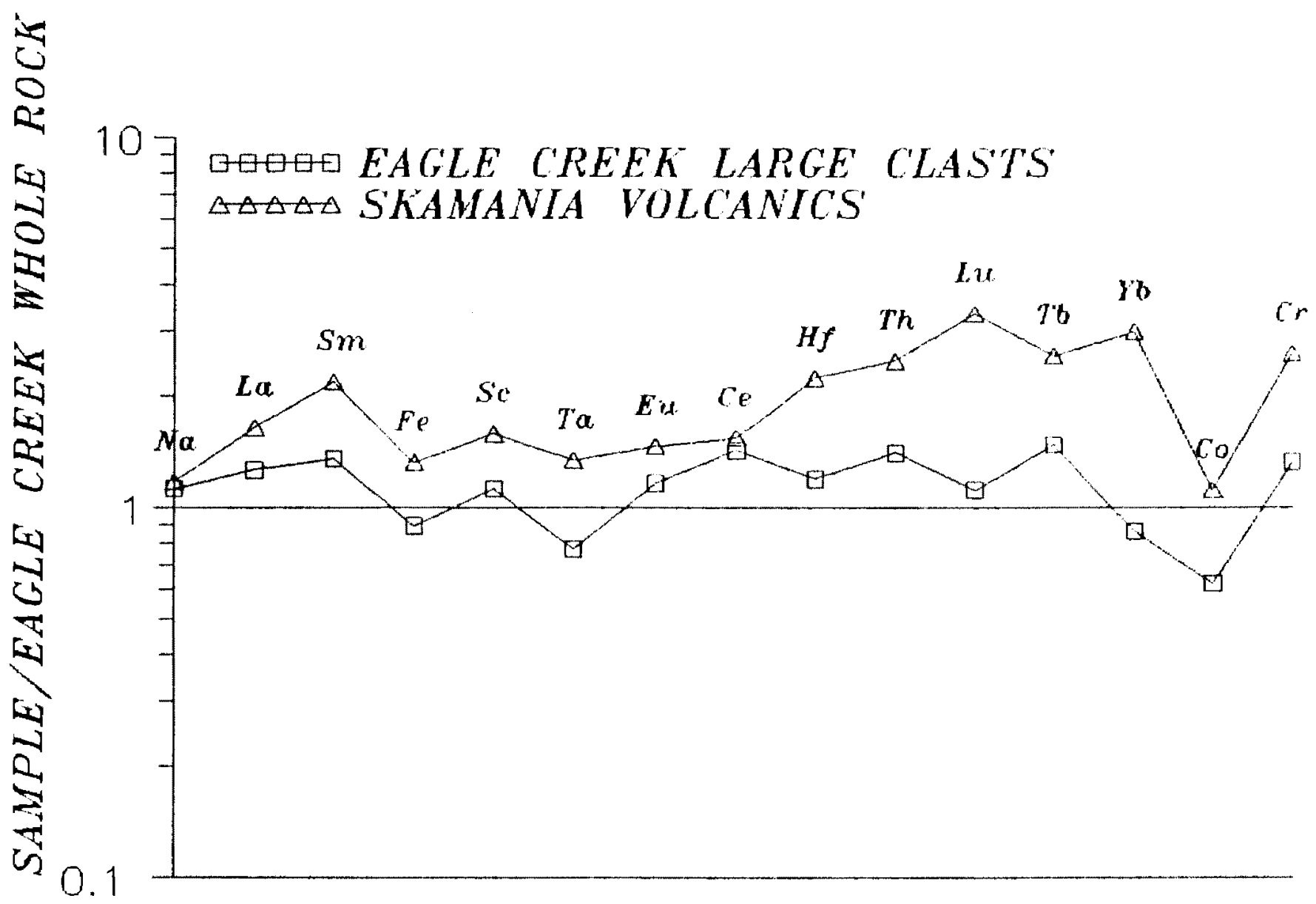

Figure 13. A plot of element concentrations in large Eagle Creek Formation clasts and Skamania Volcanic Series. Sample averages have been normalized to average Eagle Creek whole rock concentrations. 


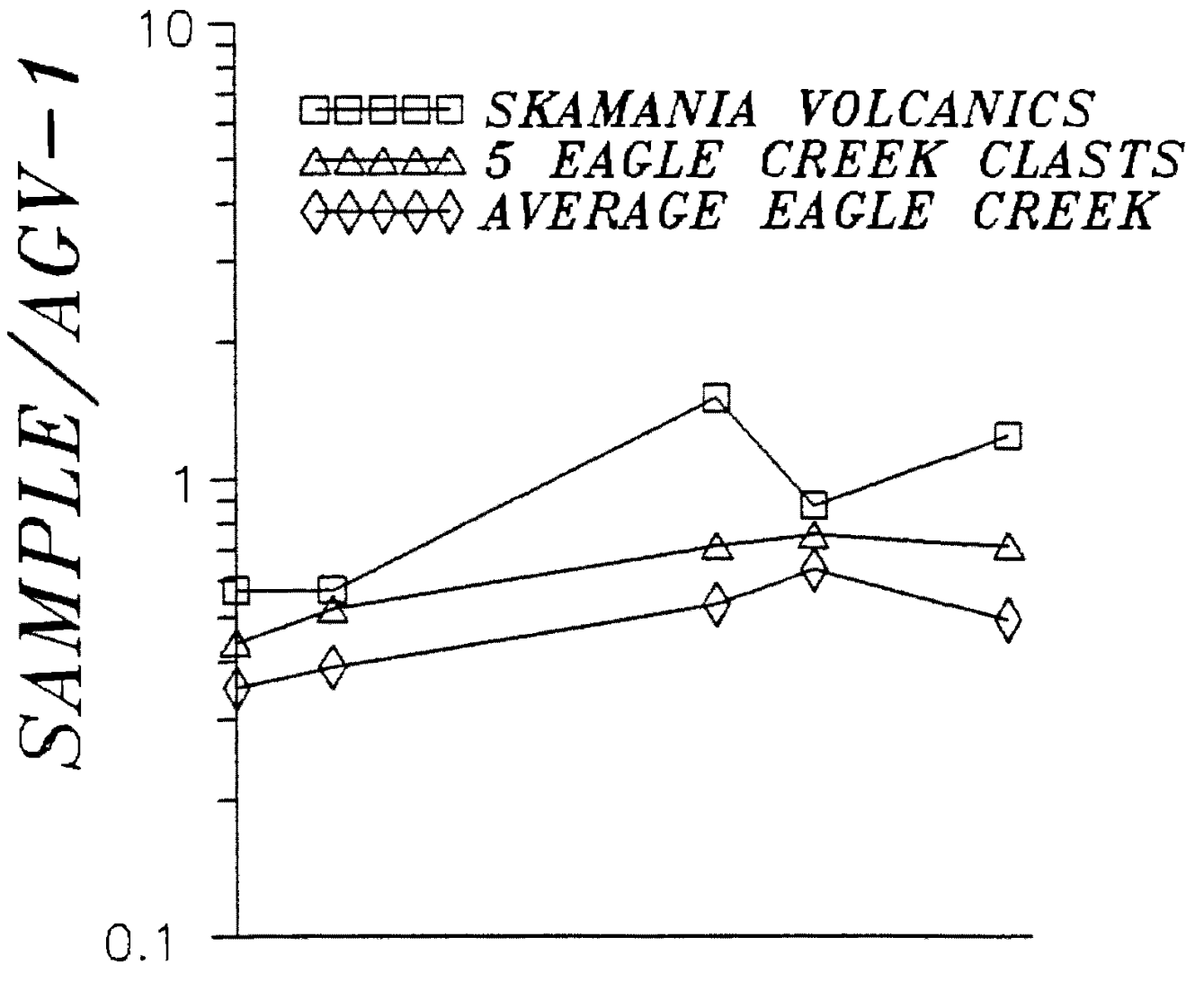

La Ce Sm Eu Tb

Figure 14. Rare earth element spider diagram of Eagle Creek Formation and Skamania Volcanic Series. Note pronounced negative Eu anomaly in the Skamania Volcanic Series and slightly positive Eu anomaly in the Eagle Creek Formation (whole rock and large clasts). 
the Columbia River Basalt Group was able to cross the Cascade arc and proceed toward the modern Oregon coast. The required topographic low might have developed some time before the eruption of the CRBG and allowed the thick accumulation of the Eagle Creek Formation. This idea would a1so allow rapid burial of the formation by the CRBG. Within the Eagle Creek Formation, the rare earth elements are positively correlated with $\mathrm{Na}_{2} \mathrm{O}$ as shown by a plot of $\mathrm{Na}_{2} \mathrm{O}$ versus La (Figure 15). The samples which do not follow this pattern are RC 5, EC 12-A, and EC 12-B (see Figures 8 and 10 for sample locations): they are all significantly depleted in $\mathrm{Na}_{2} \mathrm{O}$. Sample $\mathrm{RC} 5$ is a tuff clast. EC 12-A and $-B$ are two samples altered as a result of an intrusion on the west side of Eagle Creek. Also plotted in Figure 15 are average compositions of basalt, basaltic andesite, and andesite from the Cascades, Alaska, and the Aleutians (Ewart, 1982). While it appears that there are a lot of secondary clays in hand samples of the Eagle Creek Formation (Appendix A), it seems that the bulk chemistry has not been affected because the Eagle Creek samples and the average rock samples plot on the same line. One final observation of the general geochemistry of the Eagle Creek Formation indicates that different size fractions do, indeed, have variable compositions. In a plot of $\mathrm{Cr}$ vs Co (Figure 16) the four size fractions of sample RC 7 show a steady increase in Co concentration with a decrease 


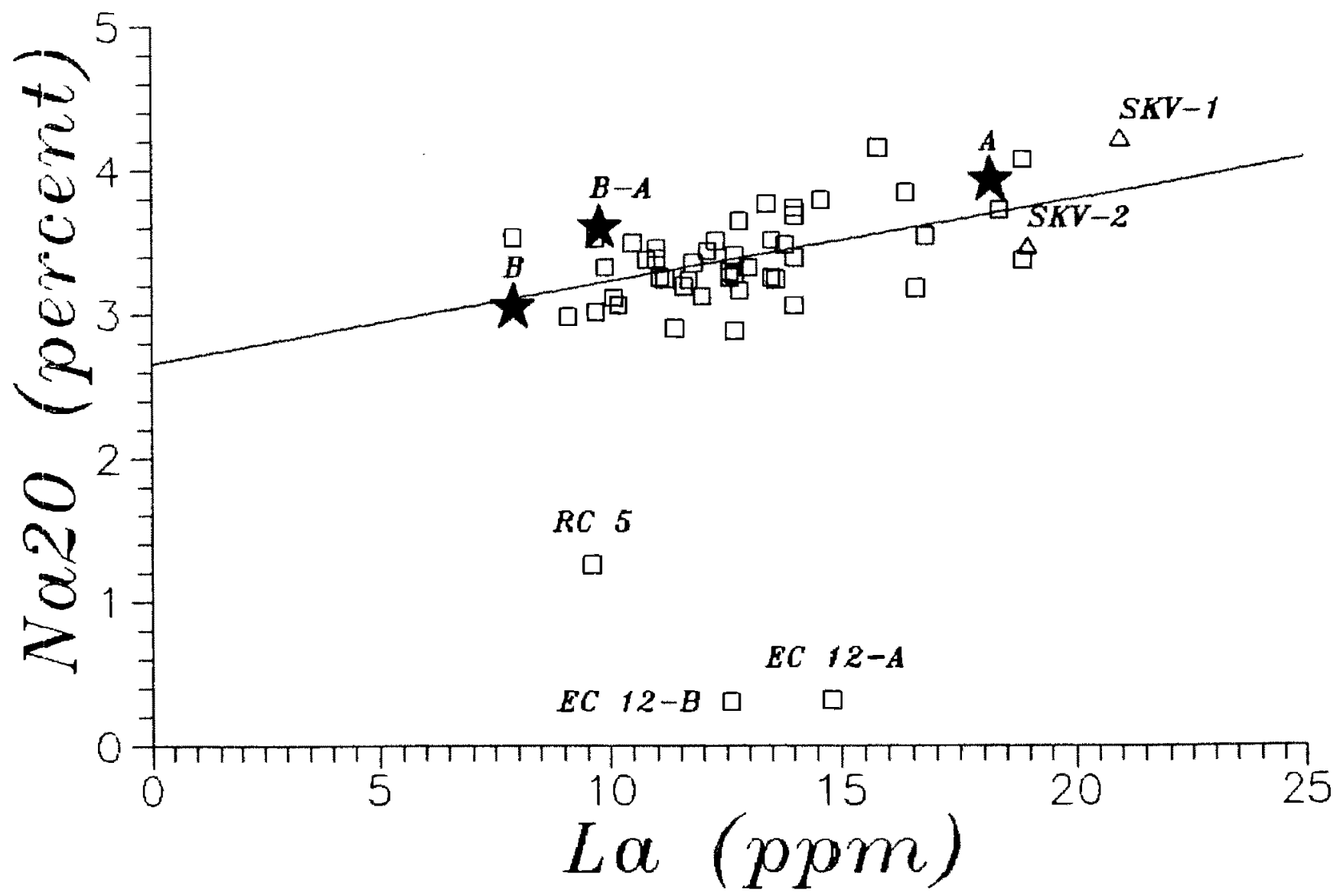

Figure 15. Plot of $\mathrm{Na}_{2} \mathrm{O}$ (wt \%) versus La (ppm). Squares are Eagle Creek Formation. Triangles are Skamania Volcanic Series. Large stars are average basalt (B), basaltic andesite (B-A), and andesite (A) from the Cascades,

Alaska, and the Aleutians (Ewart, 1982). See text for explanation of labelled Eagle Creek samples. Equation of line: $y=0.06 x+2.66$. Correlation

coefficient: $r=0.51$. 


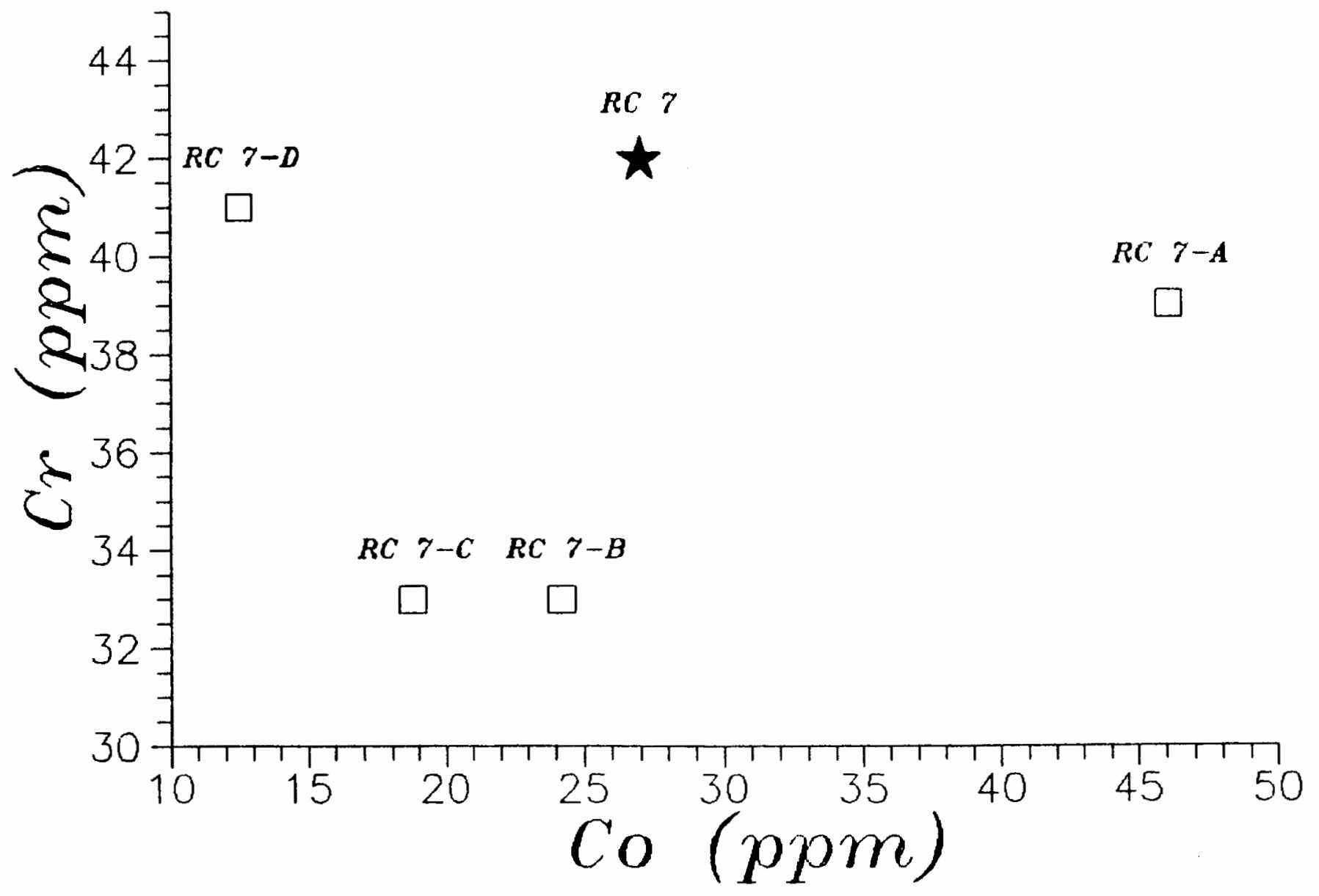

Figure 16. Plot of $\mathrm{Cr}$ versus Co showing chemical variation between different size fractions. RC 7-A: very fine sand, RC 7-B: fine to medium sand, RC 7-C: coarse to very coarse sand, RC 7-D: small to medium pebble. See text for actual sieve sizes. 
in size. There also seems to be high Cr concentrations in both the the finest and coarsest fractions. This phenomenon might be explained by a higher $\mathrm{Cr}$ content in the glass and volcanic rock fragments as compared to the plagioclase sand which makes up the matrix.

\section{STATISTICAL ANALYSIS}

The purpose for analyzing replicate samples in this study was to create a database on which to perform statistical analysis which would allow conclusions to be drawn with some degree of certainty. In the following two examples, an attempt was made to make lateral correlations in the Eagle Creek Formation to establish stratigraphic markers. Although no correlations can be made at this point, a new method was developed to visualize the statistical conclusions.

In the first example, sample sets MCC 25 and EC 15 (see Figures 8 and 9 for sample locations) were tested. At McCord Creek, a 46 centimeter thick tephra layer (Figure 17) was found at the base of the outcrop on the west side of the creek. This layer is composed of $25.4 \mathrm{~cm}$ of 1 ight purple siltstone containing abundant carbonized wood fragments and abundant fine-grained, rounded clasts up to $5 \mathrm{~mm}$ in diameter which resemble accretionary lapilli. Above this layer is 1.3 cm of altered, fine-grained sandstone which grades into $17.9 \mathrm{~cm}$ thick layer of light gray, laminated, fine-grained 


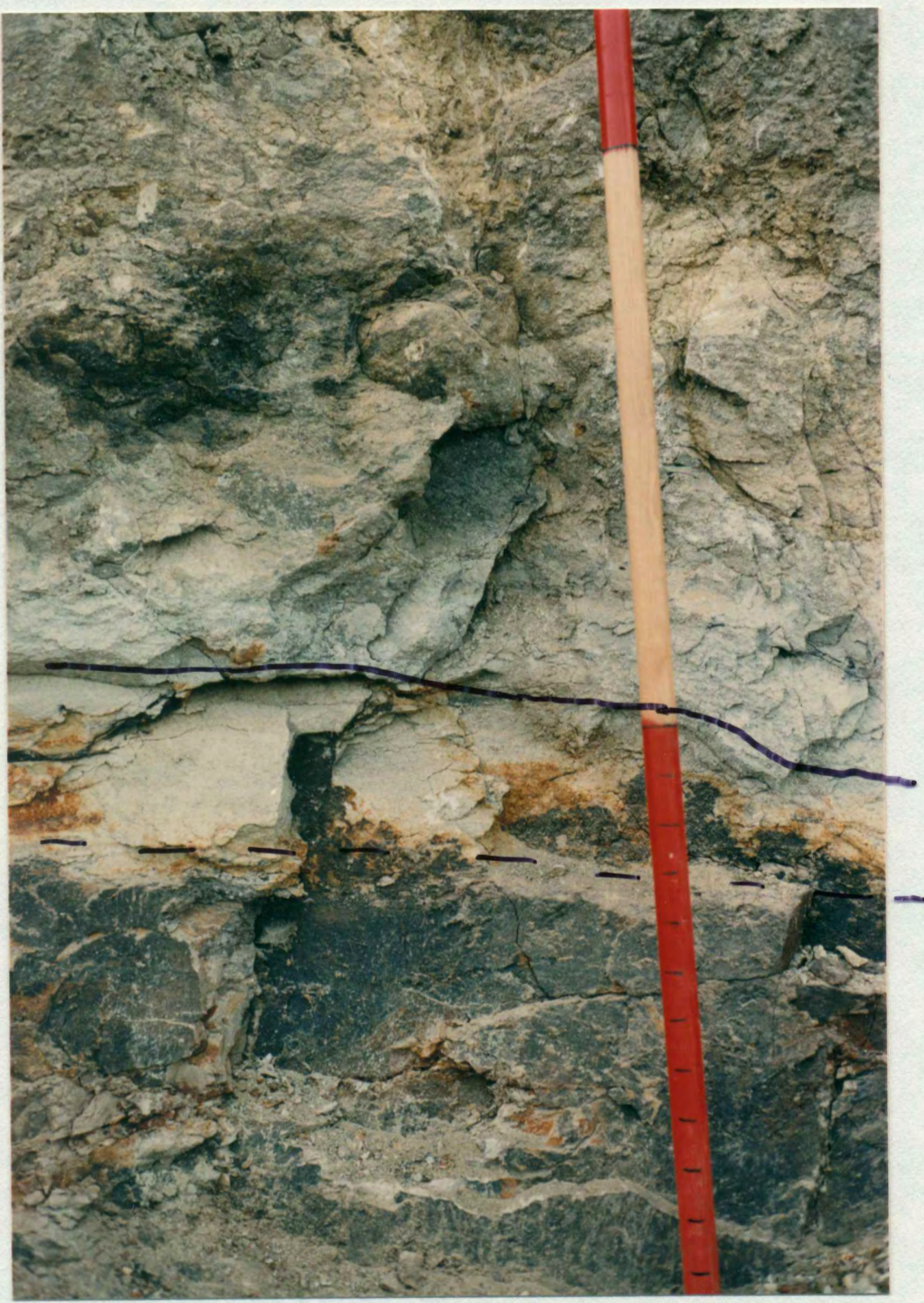

Figure 17. Tephra layer at McCord Creek. Basal purple siltstone contains abundant carbonized wood fragments and rounded pumice fragments. 
sandstone containing stringers of the apparent accretionary lapilii. Petrographically, these lapilli are only rounded pumice fragments with little or no internal structure. However, because of the texture of this unit and the abundance of plant remains, this layer is still presumed to be a tephra deposit.

At Eagle Creek, this same sequence was found on the bench above the exit ramp from I-84 (see Figure 9), except that the texture is much coarser. The best way to compare these samples would have been to analyze only the finer fractions since it was shown earlier that there are chemical variations between different size fractions. However, the Eagle Creek sample was so well indurated that it would have been practically impossible to remove the coarsest fractions in order to compare the unit to the one at McCord Creek.

The variances and means of 12 elements were tested between the two units using the F-test and t-test (Tables II and III) at the $95 \%$ confidence level. The results show that seven of the twelve elements have statistically different means. Four of these seven elements are immobile elements which also supports the conclusion that these are different units. Thus, it is clear that the two units have different compositions and are not correlative.

In the second example, sample sets RC 3 and TC 7 were tested. While petrified and carbonized wood is quite common in the Eagle Creek Formation, upright petrified trees are 
TABLE II

\section{MEANS AND STANDARD DEVIATIONS OF ELEMENTS IN SAMPLES MCC 25 AND EC 15 AND SAMPLES RC 3 AND TC 7}

MCC 25

$(n=10)$

\section{ELEMENT}

$\mathrm{Na}$

La

$\mathrm{Sm}$

$\mathrm{Fe}$

$\mathrm{Sc}$

$\mathrm{Co}$

$\mathrm{Cr}$

$\mathrm{Hf}$

Th

$\mathrm{Ta}$

$\mathrm{Ce}$

$\mathrm{Eu}$
STANDARD

DEVIATION

3.16

12.8

3.23

2.86

9.92

16.6

29.9

3.94

2.82

0.73

27.2

1.28
0.19
1. 11
0.28
0.16
0.86
3.66
5.02
0.19
0.23
0.04
2. 58
0.09

$$
\begin{aligned}
& \mathrm{RC} 3 \\
& (n=6)
\end{aligned}
$$

3.25

13.5

3.4

5.81

13.6

18.0

39.3

3.42

3.08

0.63

30.3

1. 21
0.07

1.37

0.21

.032

0.53

0.90

4.13

0.29

0.29

0.06

2. 27

0.06
EC 15

$(n=10)$

MEAN

STANDARD

DEVIATION

3.50

0.19

12.3

2.71

3.90

11.0

8.28

60.1

2.92

1.81

0.56

25.0

1.06

1. 11

0.34

0.58

0.51

0.64

6.17

0.25

0.21

0.07

1. 70

0.05
TC 7

$(n=6)$
3.19

11.6

2.88

6.10

13.2

19.8

33.5

3.30

2. 56

0.60

24.5

1.04
0.05

1. 39

0.20

0.38

1. 27

2. 08

8. 89

0.21

0.21

0.09

3.03

0.04 
TABLE III

STATISTICAL COMPARISON OF VARIANCES AND MEANS

BETWEEN SAMPLES MCC 25 AND EC 15

AND SAMPLES RC 3 AND TC 7

MCC 25 vs EC 15

\begin{tabular}{|c|c|c|c|c|}
\hline ELEMENT & $\begin{array}{l}\text { F-VALIIE } \\
(=5 \%)\end{array}$ & F-CRITICAL & $\begin{array}{c}t-\text { VALUE } \\
(=54)\end{array}$ & $t-C R I T I C A$ \\
\hline Na & 1.01 & 3.18 & -4.12 & $+/-2.10$ \\
\hline Ln & 1.02 & 3.18 & 0.847 & $+1-2.10$ \\
\hline $\mathbf{S m}$ & 1.57 & 3.18 & 3.75 & $+/-2.10$ \\
\hline Fe & 13.4 & 3.18 & $N, A$. & $--m-\cdots$ \\
\hline se & 2.91 & 3.18 & -0.057 & $+1-2.10$ \\
\hline Co & 33.4 & 3.18 & N.A. & $-\cdots-\cdots$ \\
\hline $\mathrm{Cr}$ & 1.51 & 3.18 & -12.0 & $+/-2.1 n$ \\
\hline He & 1.72 & 3.18 & 10.3 & $+1-2.10$ \\
\hline Th & 1.27 & 3.18 & 10.4 & $+1-2.10$ \\
\hline TA & 3.60 & 3.18 & N.A. & $---\cdots$ \\
\hline $\mathrm{Ce}$ & 2.29 & 3.18 & 2.27 & $+/-2.10$ \\
\hline $\mathbf{E u}$ & 2.89 & 3.18 & 6.53 & $+/-2.10$ \\
\hline
\end{tabular}

CONCLUSION

MEANS DIFEERENT

CAN'T TELL IF MEANS DIFFERENT MEANS DIFFERENT

VARIANCES DIFFERENT

CAN'T TELL IF MEANS DIFFERENT

VARIANCES DIFEERENT

MEANS DIFFERENT

MEANS DIFFERENT

MEANS DIFFERENT

VARIANCES RIFFERENT

MEANS DIFFERENT

MEANS DIFFERENT

RC 3 vg TC 7

$\begin{array}{lllll}\text { Na } & 2.29 & 5.05 & 1.58 & +/-2.57 \\ \text { La } & 1.03 & 5.05 & 2.39 & +1-2.57 \\ \text { Sm } & 1.10 & 5.05 & 4.33 & +/-2.57 \\ \text { Fe } & 1.44 & 5.05 & -1.37 & +/-2.57 \\ \text { Se } & 5.71 & 5.05 & \text { N.A. } & -2 .--- \\ \text { Co } & 5.28 & 5.05 & \text { N.A. } & ------ \\ \text { Cr } & 4.63 & 5.05 & 1.45 & +/-2.57 \\ \text { Hf } & 1.85 & 5.05 & 0.591 & +/-2.57 \\ \text { Th } & 2.03 & 5.05 & 3.54 & +/-2.57 \\ \text { Ta } & 2.14 & 5.05 & 0.701 & +/-2.57 \\ \text { Ce } & 1.79 & 5.05 & 3.75 & +/-2.57 \\ \text { Eu } & 2.24 & 5.05 & 5.49 & +/-2.57\end{array}$

CAN'T TELI, IF MEANS DIFFERENT CAN'T TELL IF MEANS DIFFERENT MEANS DIFFERFNT

CAN'T TELL IF MEANS DIFFERENT VARIANCES DIFFERENT

VARIAHCES DIFFERENT

CAN"T TELL IF MEANS DIFFEREHT CAN'T TELL IF MEANS DIFFERENT MEANS DIFFERENT

MEANS DIFFERENT
CAN'T TELL IF MEANS DIFFERENT MEANS DIFFERENT

MEANS DIFFERENT 
rare. In the outcrop on the west side of McCord Creek, a soil zone containing two upright petrified trees (Figure 18) separates two lower units from one upper unit. Sample RC 3 was taken from the uppermost unit. On the west side of Tanner Creek three upright petrified trees were found near road level (Figure 19). Sample TC 7 was taken from above the soil zone.

The attempt to correlate two seemingly different rock types (Appendix A) was undertaken because upright petrified trees are a rarity in the Eagle Creek Formation; perhaps they were preserved during the same eruptive episode. If so, another lateral stratigraphic correlation might be established. Again, the variances and means of 12 elements were tested (Tables II and III) at the $95 \%$ confidence level. In this example, only four of the twelve elements had statistically different means. But, one must still conclude that these two samples are not correlative, especially because three of these four elements are immobile elements.

To better visualize the differences discussed above, a method to differentiate between sample sets was developed as part of a class project (Rachel Carlin and Willard Titus, 1987). In this case, a composite of the same 12 elements used above was analyzed. Cluster analysis is a method to differentiate between dissimilar units. However, it was found that tuffs and volcaniclastic sediments have too many genetic similarities to be efficiently clustered. The 


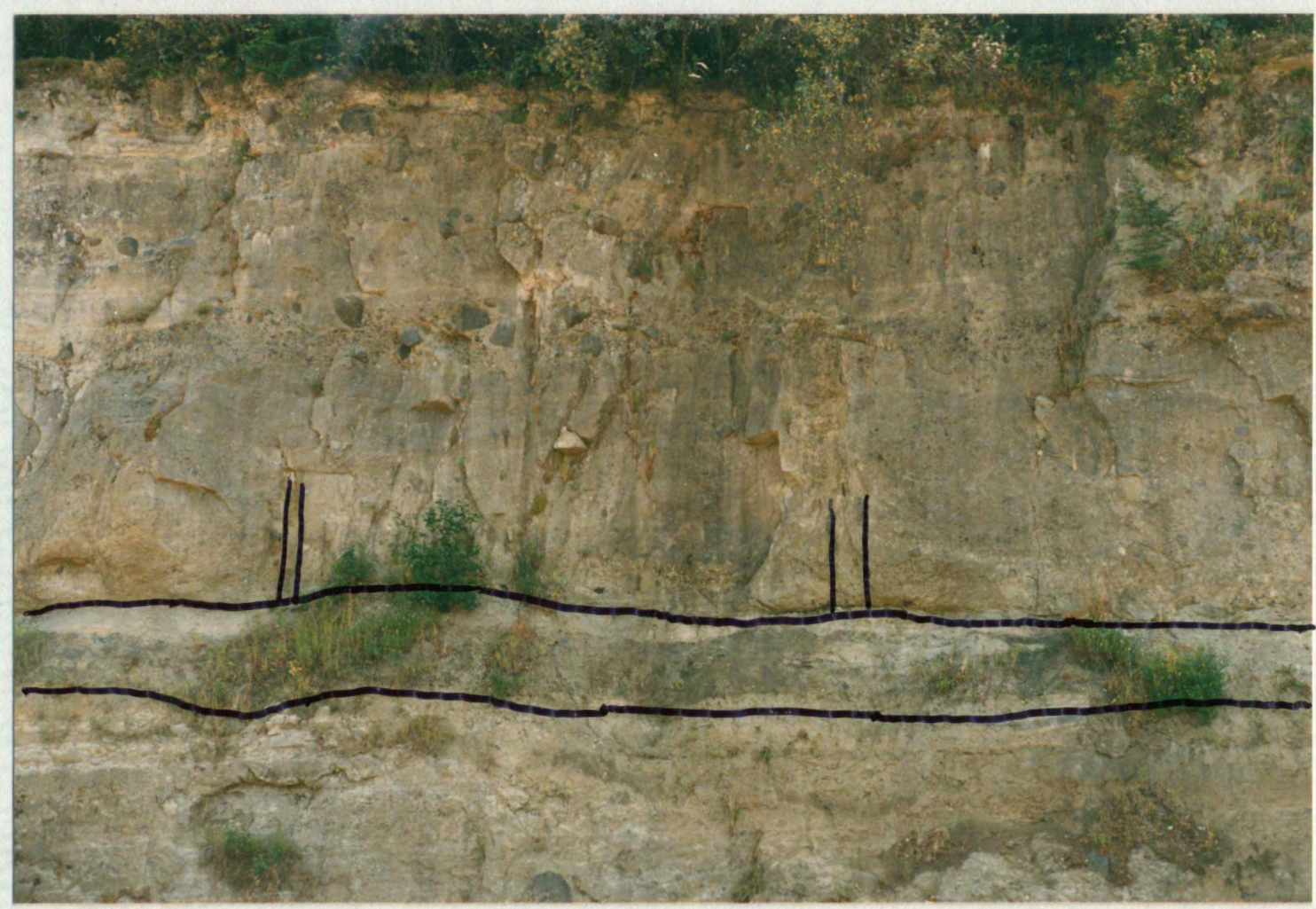

Figure 18. Eastern part of outcrop on the west side of McCora Creek. Significant unit here is soil zone containing two upright petrified trees. 


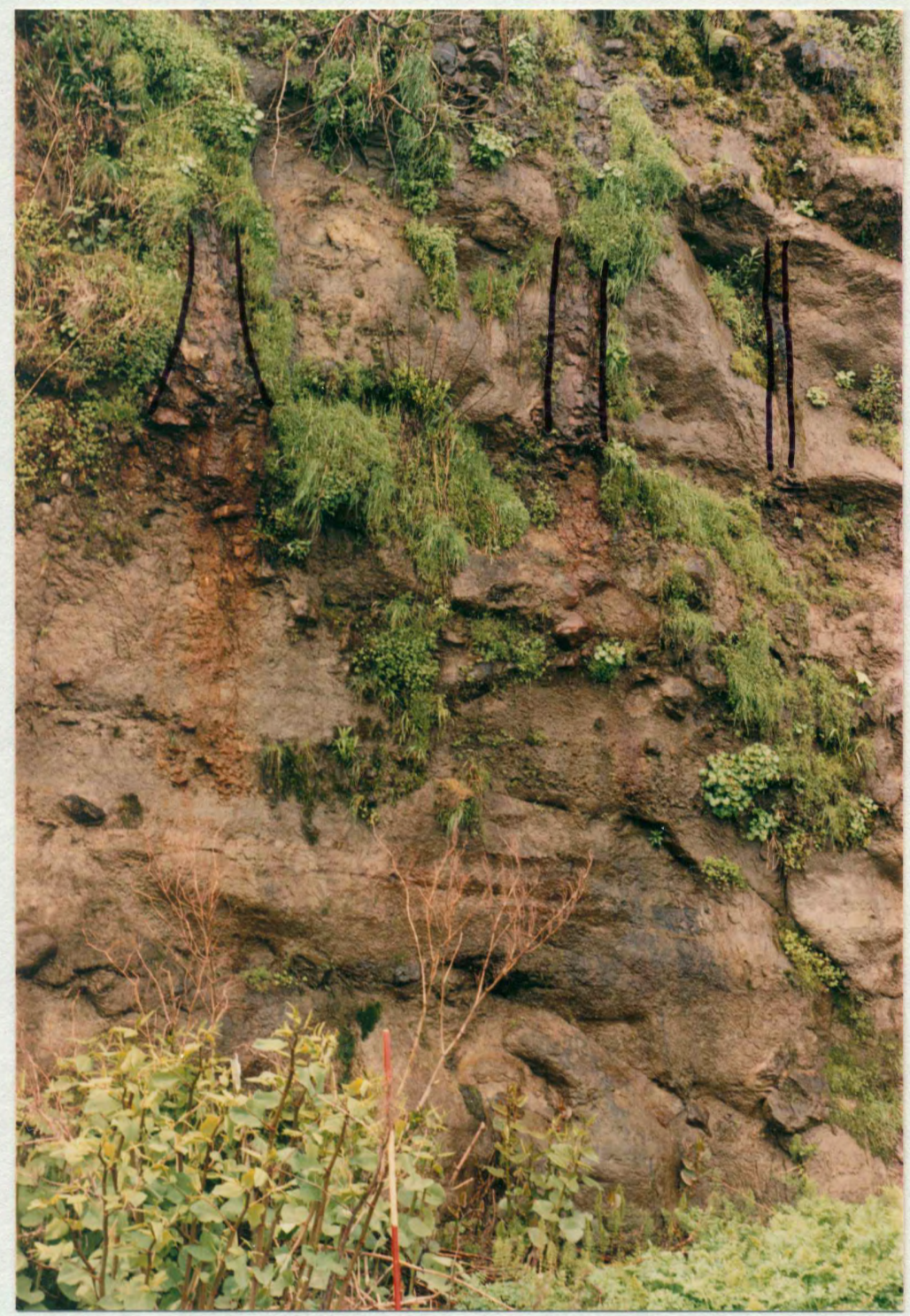

Figure 19. Western part of outcrop on the west side of Tanner Creek. Note three upright petrified trees. Also note orange staining below trees which is almost always associated with petrified wood in the Eagle Creek Formation. This associated is useful in identifying possible soil zones and tephras from a distance. 
correlation coefficients between samples was greater than 0.9. To alleviate this problem and to exaggerate differences between units, principal component analysis was run on the data first. Then the principal component scores (eigenvectors) which represented 90-95\% of the variability of the 12 elements in the samples were used as the data set in cluster analysis. This method proved to be very good at producing the expected results. In Figure 20 all four of the samples sets used above were analyzed at the same time. Each branch off the basal sample is considered one group. It can be seen that each sample set falls into its own group with one exeption: TC 7-A is grouped with sample set RC 3 . This one "mistake" in 32 samples is equivalent to a $97 \%$ success in producing the expected results.

\section{TRACE ELEMENT FINGERPRINTING}

The task of identifying individual mudflow units in the field without the presence of a soil zone, charcoal layer, or tephra layer is very difficult. This study was partly intended to determine whether mudflow units could be fingerprinted using trace element geochemistry. The discussion above on testing whether two samples were different, showed that, indeed, trace element signatures can be more useful than major element chemistry. Sample sets $R C 3$ and TC 7 are statistically different, but these two samples have nearly identical major element concentrations (Appendix C). 


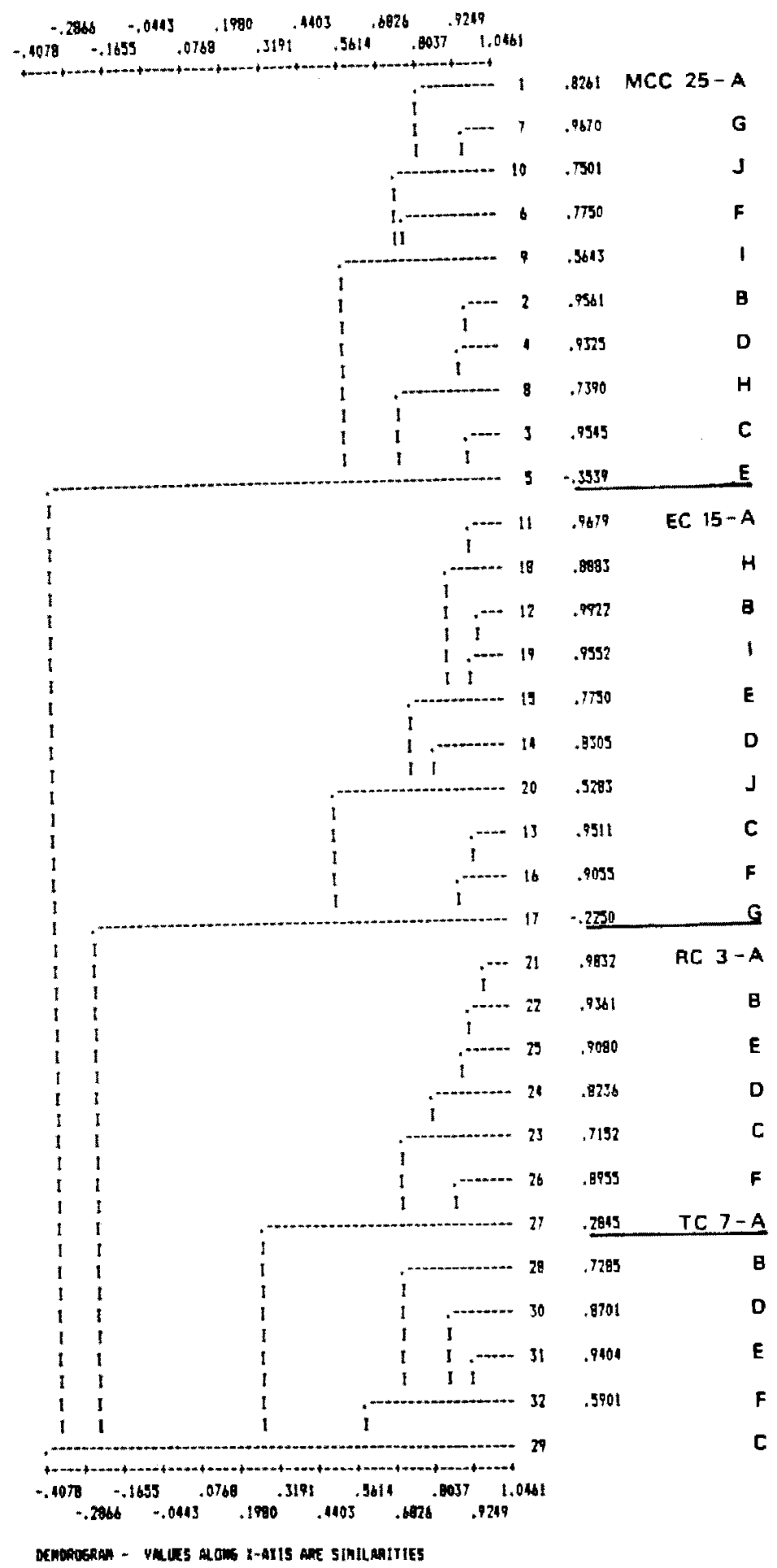

Figure 20. Dendrogram showing principal component-cluster analysis groupings. All replicates of a sample are grouped together except for one, TC 7-A, which plots with the RC 3 samples. 
The outcrop on the west side of McCord Creek was tested to see if trace element fingerprinting was possible. Here, field evidence indicated that there were three distinguishable units: two below and one above an identifiable soil zone (upright petrified trees exposed, see Figure 18) (Figure 21). The two lower units were more difficult to identify. The decision to call them two units was based on textural differences and the presence of an approximately $3 \mathrm{~cm}$ thick discontinuous ashy layer containing a high concentration of carbonized wood fragments. Texturally, the lower unit grades from a matrix-to clast-supported cobble/boulder conglomerate to coarse-grained volcaniclastic sandstone to medium-grained sandstone. The second unit is a matrix-to clast-supported cobble conglomerate.

When the relationship between these three units is shown graphically (Figure 22a), it is quite evident that there are significant chemical differences among the three units. This result is also produced with other plots including the Fe/Sc versus La/Sm ratios (Figure 22b). The reason for using ratios is that in similar rocks, each element can have a relatively large concentration range, but ratios remain fairly constant (Marvin Beeson, oral communication). Therefore, using ratios emphasizes the differences between each rock unit.

As a final test of these results, the principal 


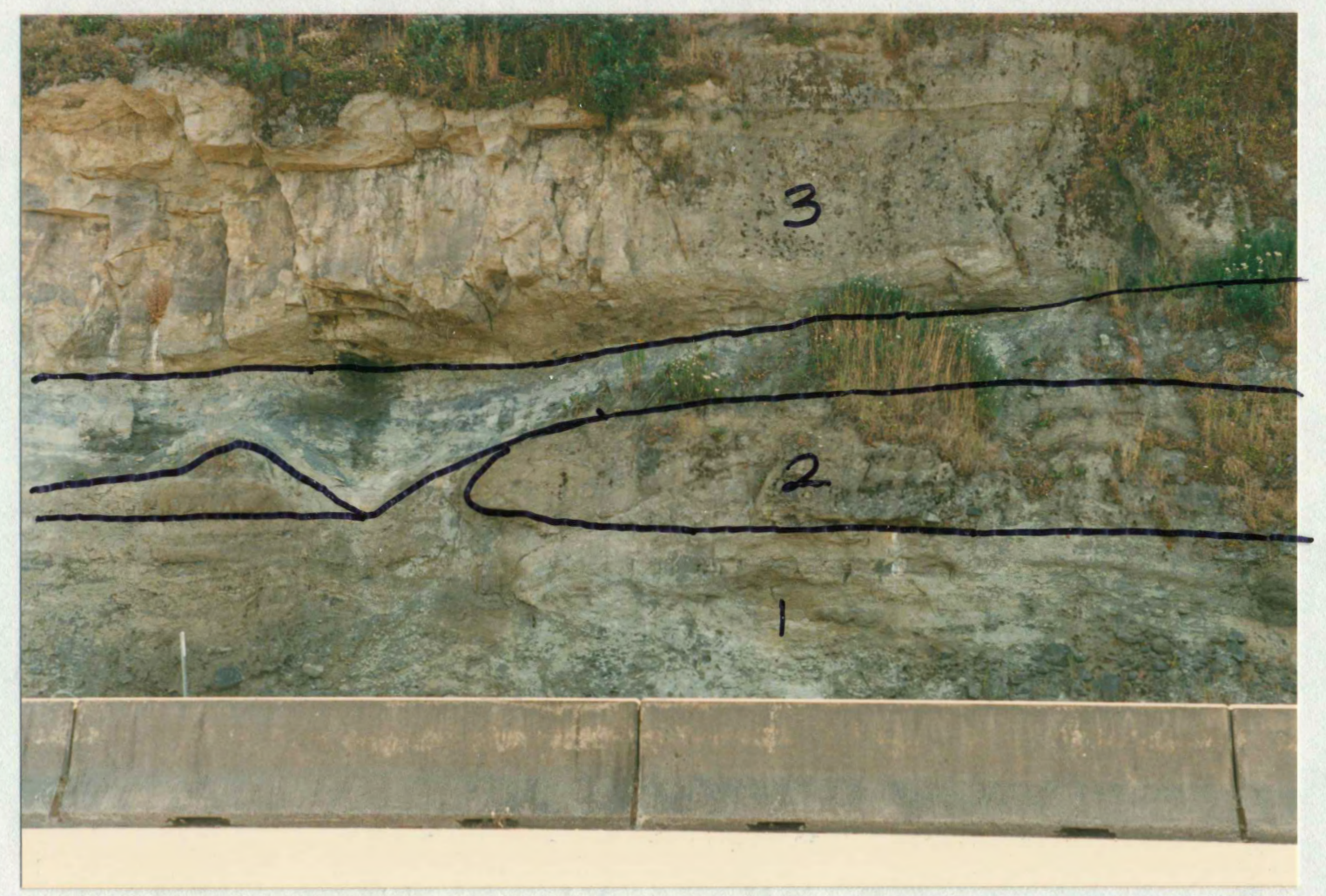

Figure 21. Western part of outcrop on the west side of McCord Creek showing tree mudflow units and soil zone. 

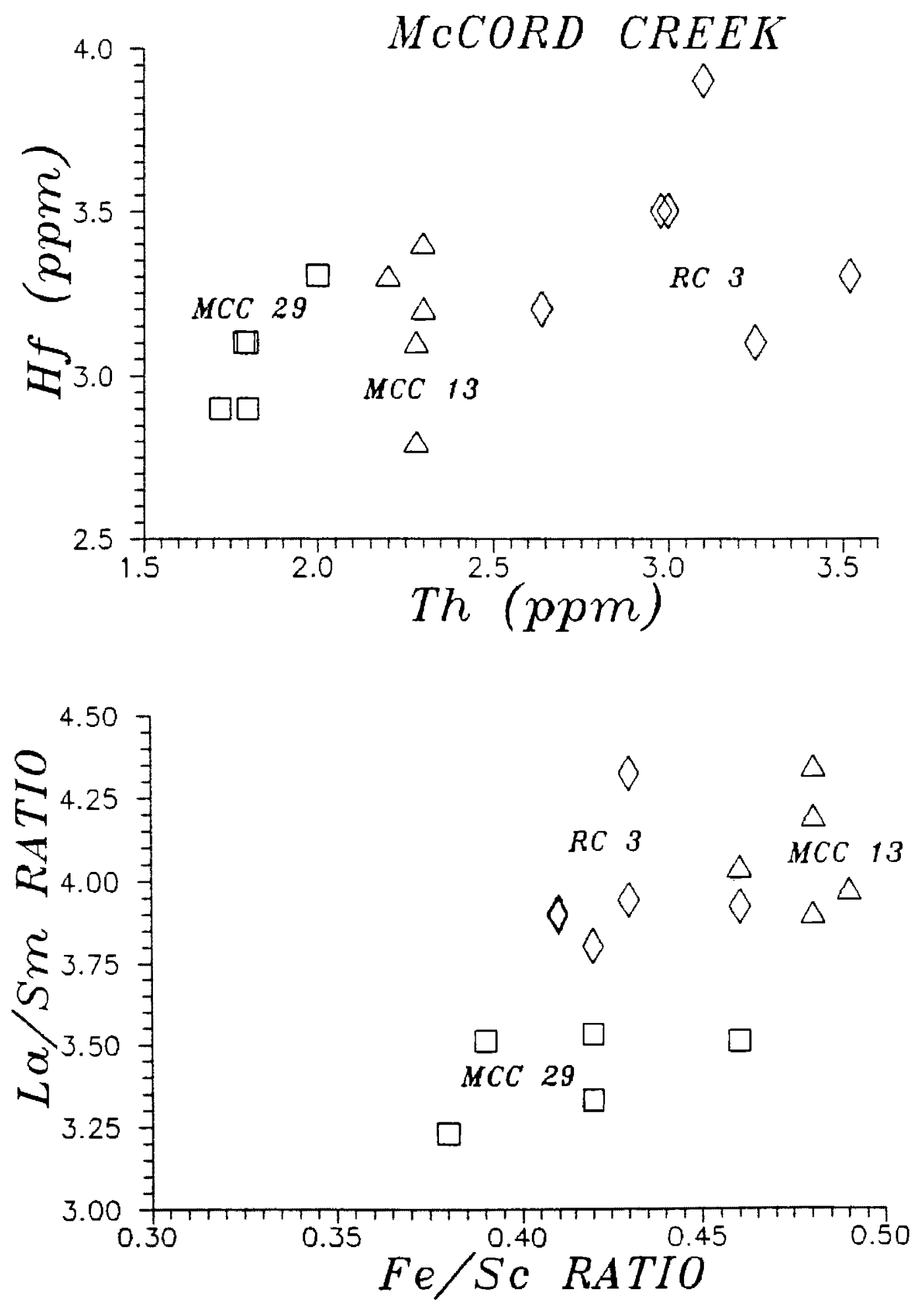

Figure 22. A and B: Trace element plots which show the distinctions between three mudflow units at McCord Creek. Each point represents a replicate analysis. 
component analysis-cluster analysis combination was used with the six elements shown in Table IV. Using three of the principal component scores ( $90 \%$ of variability in rocks), the cluster program produces the three groupings expected (Figure 23) with only three "mistakes". This deviation from the expected result is $81 \%$ accurate in dividing the outcrop into three units.

As a result of these analyses, it can be seen that perceptible chemical differences exist between mudflow units. By being able to differentiate between units, this method is useful in substantiating questionable field relationships because we11-1ithified mudflows are difficult to distinguish from each other.

\section{GEOCHEMICAL STRATIGRAPHY}

Statistical analysis showed that determining lateral correlations using trace element chemistry is very difficult and may not always work, especially in rocks which are fairly uniform chemically. Using the principal componentcluster analysis combination again, an attempt was made to determine a geochemical stratigraphy in the Eagle Creek Formation. Six immobile elements (Hf, Th, La, Sc, Co, and Ce) were chosen by plotting element concentrations against stratigraphic position of the 14 samples collected along the Eagle Creek Trail. Mobile elements and those elements with fairly constant concentrations throughout the section were 


\section{TABLE IV}

ELEMENT CONCENTRATIONS IN THE THREE MCCORD CREEK UNITS

Sm La $\quad$ Fe $\quad S c \quad H f \quad$ Th

$\begin{array}{llllll}3.24 & 12.7 & 6.28 & 13.65 & 3.90 & 3.10 \\ 3.73 & 16.1 & 5.73 & 13.19 & 3.30 & 3.52 \\ 3.47 & 13.5 & 5.33 & 12.97 & 3.20 & 2.64 \\ 3.49 & 13.6 & 5.81 & 14.18 & 3.50 & 2.98 \\ 3.37 & 12.8 & 6.02 & 14.17 & 3.50 & 3.00 \\ 3.12 & 12.3 & 5.72 & 13.17 & 3.10 & 3.25\end{array}$

\begin{tabular}{|c|c|c|c|c|c|c|c|}
\hline \multirow{5}{*}{$\mathrm{MCO}$} & \multirow{5}{*}{13} & 2.64 & 10.3 & 6.50 & 12.80 & 3.20 & 2.30 \\
\hline & & 3.22 & 13.0 & 6.00 & 13.20 & 3.30 & 2.20 \\
\hline & & 2.26 & 9.80 & 5.60 & 11.30 & 2.80 & 2.28 \\
\hline & & 2.97 & 11.8 & 5.80 & 12.30 & 3.10 & 2.28 \\
\hline & & 2.65 & 11.1 & 5.90 & 12.40 & 3.40 & 2.30 \\
\hline \multirow{5}{*}{$\mathrm{MCC}$} & \multirow{5}{*}{29} & 3.13 & 11.0 & 5.10 & 13.50 & 3.10 & 1.80 \\
\hline & & 2.92 & 10.3 & 5.00 & 12.40 & 2.90 & \\
\hline & & 2.99 & 10.5 & 6.80 & 14.50 & 3.10 & 1.8 \\
\hline & & 3.25 & 10.5 & 5.50 & 14.90 & 2.90 & 1. \\
\hline & & 3.12 & 10.4 & 5.50 & 12.80 & 3.30 & 2.00 \\
\hline
\end{tabular}

A11 concentrations in ppm except for Fe which is in oxide weight \%. 


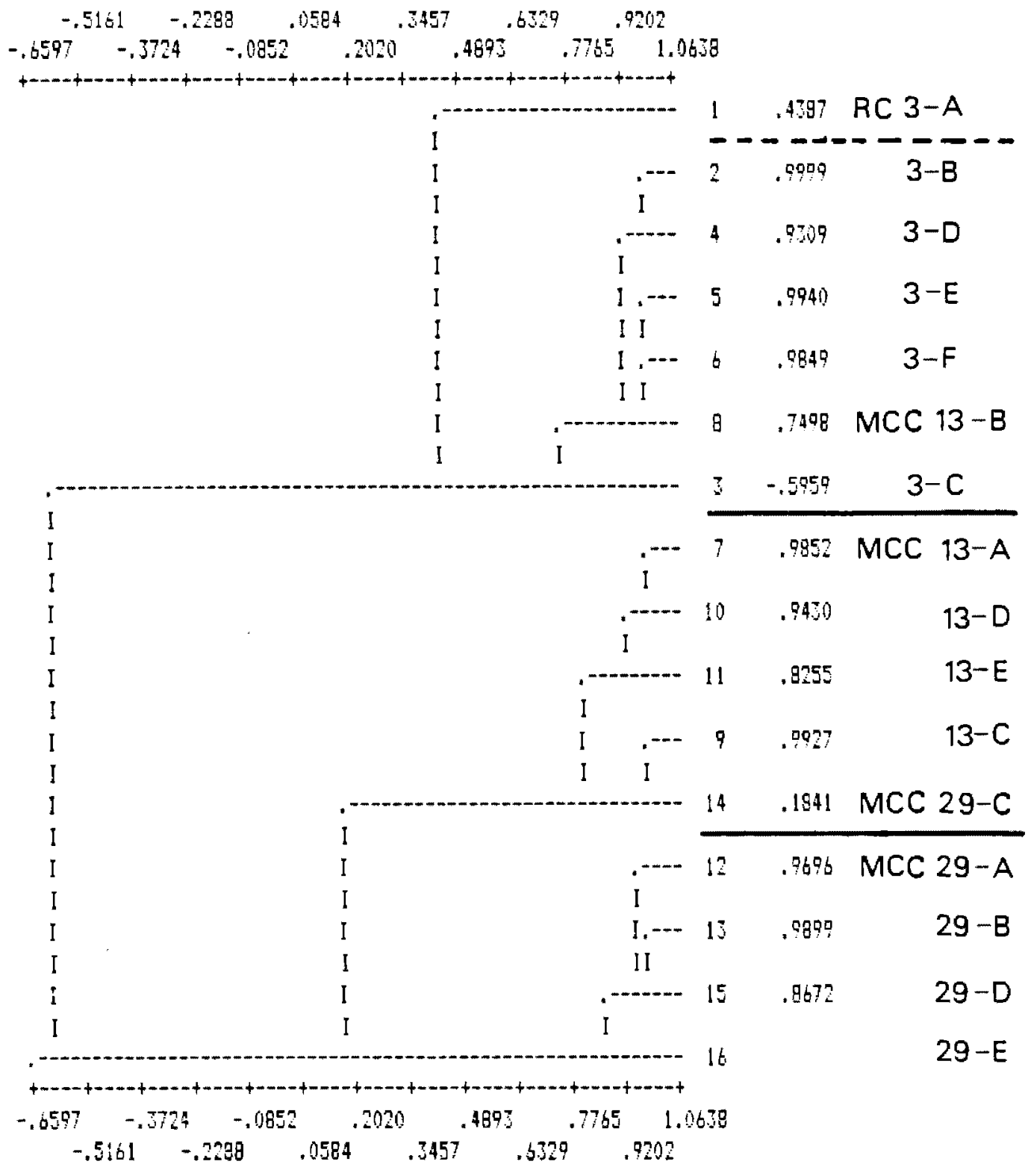

DENDFOGFAM - VALUES ALCNG X-AXIS ARE SIMILARRITIES

Figure 23. Dendrogram showing results of principal component-cluster analysis. Three groups represent three mudflow units at McCord Creek. Three errors in grouping are: RC 3-A, MCC 13-B, and Mcc 29-C (see text). 
eliminated. In addition to these 14 samples, four other samples from the Eagle Creek area (RC 7-10) and seven samples from the Tanner Creek area ( $R C 6$, TC 3 and 7-11) were analyzed. These samples represent a lower part of the section than those samples from the Eagle Creek Trail. The results show (Figure 24) that within each group, samples from the lower part of the section correlate chemically with samples from the upper part of the section; there are no recognizable patterns.

One would think that there might be a chemical stratigraphy in a thick pile of volcanic mudflows if, over time, there was an evolution of the volcano from which these deposits were derived or if the mudflows were a product of more than one volcano. So, one must ask, why is there no obvious chemical stratigraphy? I believe the following reasons can answer that question. First, as explained earlier, using principal component analysis exaggerates differences between samples which would otherwise have a high correlation coefficient. This means that the examined section of the formation is chemically uniform on a large scale. Secondly, the thickness of the section analyzed in this study is only about 61 meters. It would not take very much time, geologically, to accumulate mudflow units this thick. Perhaps if a thicker section (at least 150 meters) were analyzed, significant chemical/stratigraphic differences would be found. 


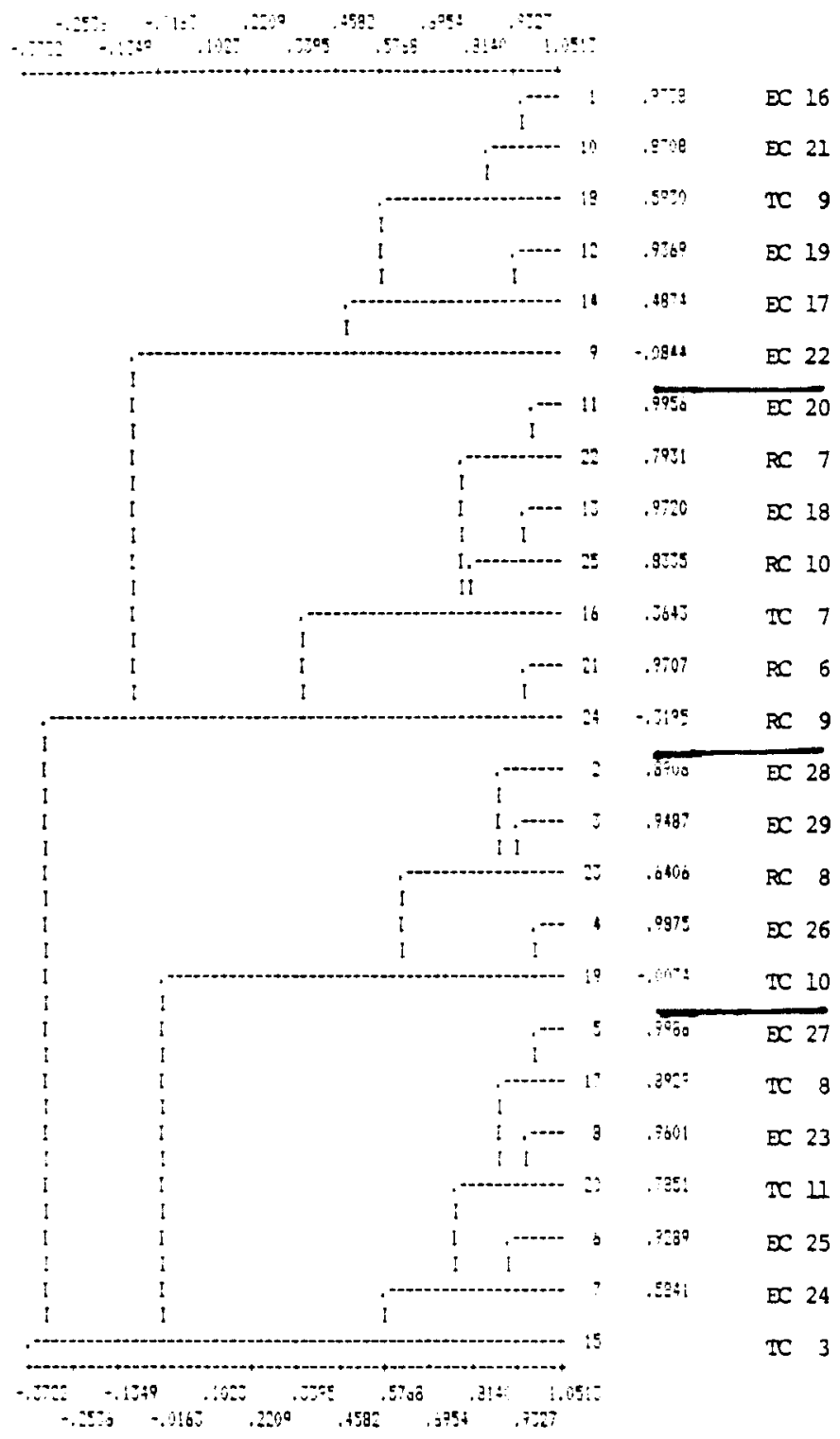

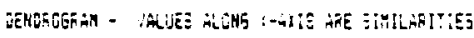

Figure 24. Dendrogram using only immobile elements to produce a geochemical stratigraphy. Samples taken from Eagle Creek and Tanner Creek areas. See text for explanation of results. 
Thus, although no geochemical stratigraphy can be established now, enough data are available as a basis for an examination of the 396 meter thick section of the Eagle Creek Formation exposed in Washington. Perhaps correlation of sections of the formation from one side of the river to the other will be possible.

\section{TECTONIC ANALYSIS}

In order to put the information in the previous discussion into geologic perspective, the Eagle Creek Formation was compared to other Western Cascade rocks. The first question one might ask is how do the lower Miocene Eagle Creek mudflows which underlie the Columbia River Basalt Group compare to the middle Miocene Rhododendron and Dalles Formations mudflows and lavas which overlie the CRBG? Using two good discriminators, $\mathrm{TiO}_{2}$ and $\mathrm{P}_{2} \mathrm{O}_{5}$, Figure 25 shows that, for the most part, the Eagle Creek Formation can be distinguished from the Rhododendron and Dalles Formations based on their $\mathrm{TiO}_{2}$ concentrations. Sometimes, the Eagle Creek Formation is considered part of the 0ligo-Miocene Little Butte Volcanic Series (Peck and others, 1964) which ranges from basalt to rhyolite. Figure 25 also shows how the Eagle Creek Formation relates to the Little Butte Volcanic Series. Notably, three samples (one basalt and two andesites) fall into the Eagle Creek Field. The other group of Little Butte samples are all dacites and rhyolites. 


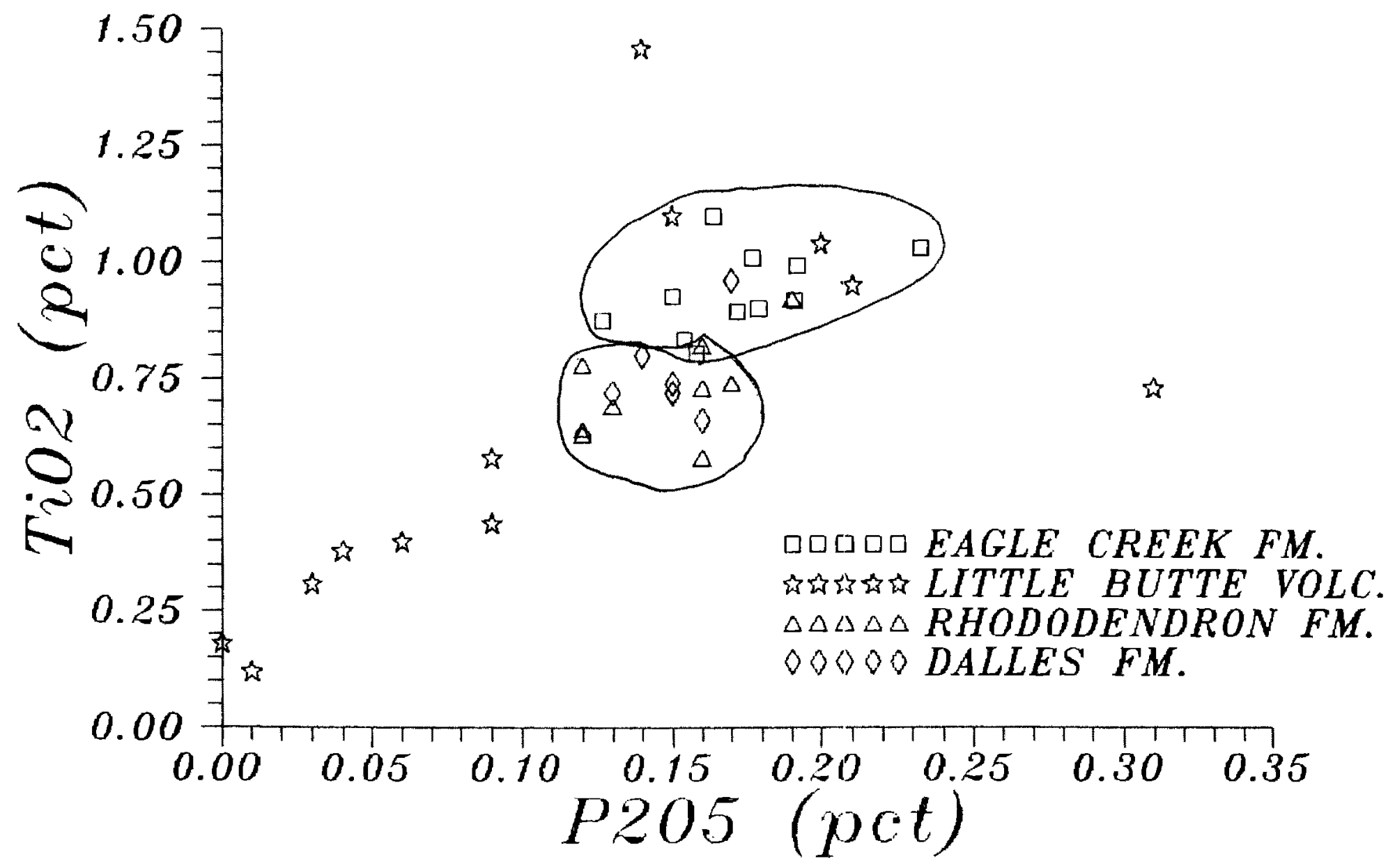

Figure 25. Plot of $\mathrm{TiO}_{2}$ versus $\mathrm{P}_{2} \mathrm{O}_{5}$. Field 1 represents Eagle Creek Formation. Field 2 represents Rhododendron and Dalles Formations. Little Butte Volcanic series data from Peck and others (1964). Rhododendron and Dalles Formations data from Gannett (1982). 
One may now ask, "do other Western Cascade rocks have their own signatures also"? Or does arc volcanism produce trends into which the Eagle Creek, Rhododendron, and Dalles Formations and the Little Butte Volcanic Series fall?

Figure 26 is the same plot as Figure 25 with the addition of middle Miocene andesites collected from an area east of Oakridge, Oregon by Sherrod (1986). These data show variations in both $\mathrm{TiO}_{2}$ and $\mathrm{P}_{2} \mathrm{O}_{5}$ which, when combined with the data from Figure 26 produce a 1 inear trend. This trend indicates that there is not much change in the $\mathrm{TiO}_{2} / \mathrm{P}_{2} \mathrm{O}_{5}$ ratio over time or space. Coupled with this interpretation is the fact that average basalt, basaltic-andesite, and andesite compositions of Tertiary-Recent age from the Cascades, Alaska, and the Aleutians also fall along the trend.

As a final question, one is tempted to ask whether the tectonic setting of the Eagle Creek Formation can be determined by its chemistry. In their study of Paleozoic graywackes in Australia, Bhatia and Crook (1986) determined that certain trace and minor element plots were very useful in differentiating between four tectonic settings:

1. oceanic island arc,

2. continental island arc,

3. active continental margin, and

4. passive continental margin.

Since graywackes and mudflows represent mixed rocks, it seemed like an interesting idea to use Bhatia and Crook's plots to see which setting the Eagle Creek Formation 


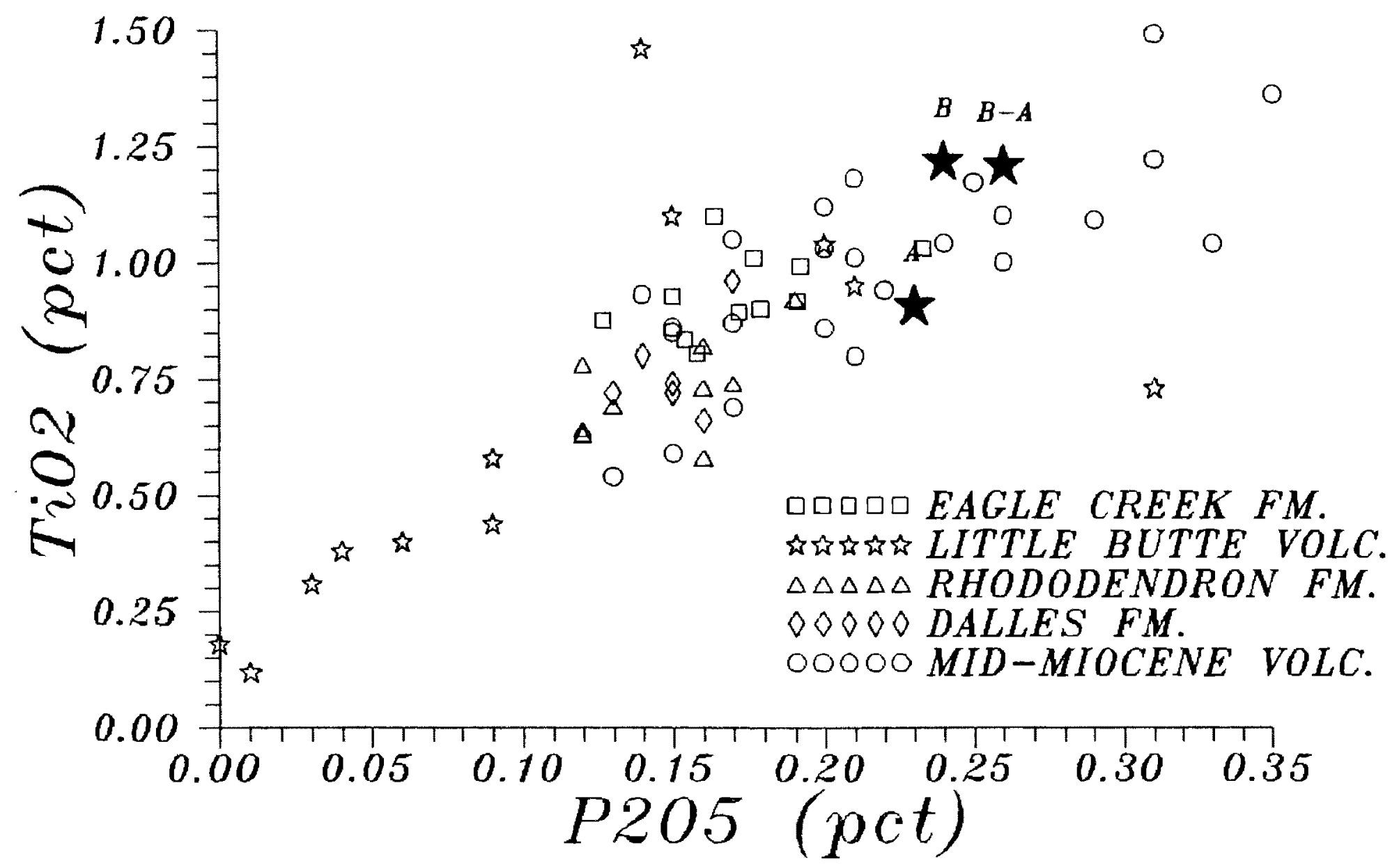

Figure 26. Same as Figure 25 with additional data. Middle Miocene volcanics from Sherrod (1986). Average basalt (B), basaltic andesite (B-A), and andesite (A) data from Ewart (1982). 
belonged to. Would the trace element relationships be more like oceanic or continental island arcs? It is worth noting Bhatia and Crook's descriptions of the crust associated with the sedimentary basins they studied. They define an "oceanic island arc" as an arc that was formed on oceanic crust or partly on thin continental crust; whereas, a "continental island arc" is defined as an arc that was formed completely on well-developed continental crust or thin continental margin. Bhatia and Crook's oceanic island arc graywacke consisted of $50-70 \%$ andesitic rock fragments with abundant plagioclase feldspar. The continental island arc graywacke was quartz intermediate with volcanic and argillaceous rock fragments. They determined that the quartz component was derived from felsic volcanism with only a minor contribution from older sedimentary rocks. They also noted that, modally, the continental island arc graywacke was similar to modern back-arc and continental arc sands. For distinguishing between the two arc settings, Bhatia and Crook concluded that the best discriminatory plot was La vs Th. These two elements are particularly we11-suited for these interpretations because they are both immobile. Figure 27 shows that the Eagle Creek Formation and also the Rhododendron and Dalles Formations plot in the oceanic island arc field. The reason these rocks plot in the oceanic island arc field may be the result of geographic location. The volcanoes which produced these rocks were 


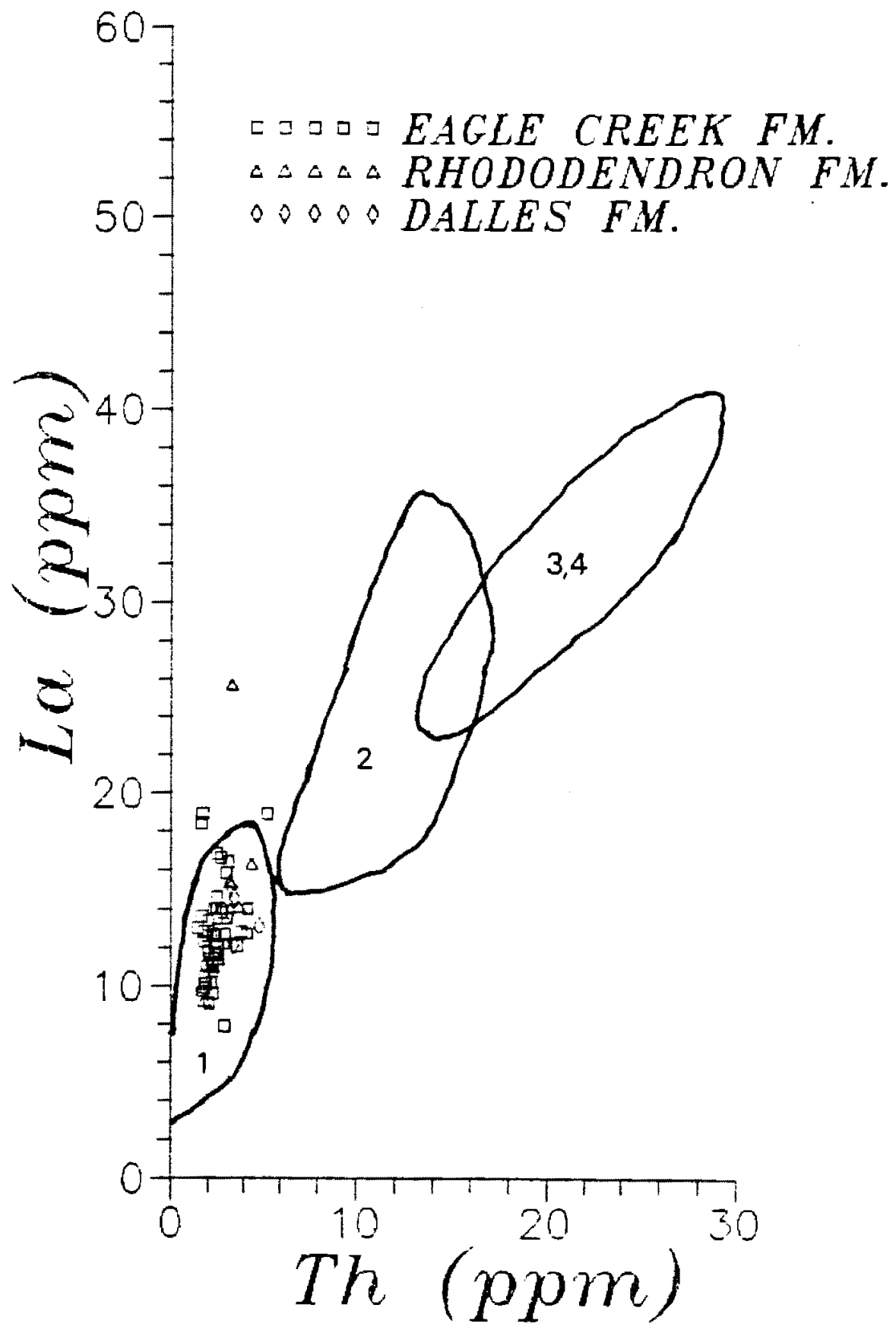

Figure 27. Plot of La versus Th showing tectonic settings. l=oceanic island arc, 2=continental island arc, 3=active continental margin, 4=passive continenetal margin. Modified from Bhatia and Crook (1986). 
developed in the Columbia embayment, the broad arc which extends from the Klamath Mountains to northeastern Oregon and southeastern Washington and then back to the olympic Mountains. It is possible that the edge of this embament represented the continental margin through the Mesozoic Period and that the floor of the embayment is composed of oceanic crust (King, 1977). During the Cenozoic Period the embayment was filled with sediments and volcanic rocks (Hammond, 1979). Thus, any volcano erupting within the Columbia embayment would not be contaminated by continental crust and would not show this influence in plots like Figure 27. 
CHAPTER IV

CONCLUSIONS

\section{SUMMARY}

To summarize, the Eagle Creek Formation is the product of andesitic to dacitic island arc volcanism which developed on oceanic crust and produced thick deposits of debris flows and mudflows. A chemical comparison showed that the Skamania Volcanic Series is not the source rock for the Eagle Creek Formation. In fact, the Skamania Volcanic Series is probably too old to be the source for the Eagle Creek Formation.

Within the Eagle Creek Formation, no lateral correlations were established. That is not to say that none can be found. Further study of this problem should focus on the many distinguishable tephras. Additionally, no vertical stratigraphic patterns were discovered. However, much of this difficulty is probably due to the lack of a thick exposure on the Oregon side of the Columbia River. Study of the Washington exposure might provide a thick enough sequence to establish a chemical stratigraphy.

Although megascopic differentiations did not work, this study has shown that trace element geochemistry can be used macroscopically as a fingerprinting technique. This 
study also established the usefulness of the principal component-cluster analysis combination when trying to differentiate between units in rocks that are chemically homogeneous.

As a final result of this study, it was shown that the Eagle Creek Formation is distinguishable from the middle Miocene, post-CRBG Rhododendron and Dalles Formations. However, comparison of these three formations with Middle Miocene andesites from the central Oregon Western Cascades, shows that arc volcanism produces certain trends which are the result of a common tectonic setting. This idea is important for further study of volcanic mudflows because whole rock analyses of the Eagle Creek Formation including both matrix and coarse fractions did not produce anomalous results when compared to the other formations in which only lava clasts and lava flows were analyzed.

\section{RECOMMENDATIONS FOR FURTHER STUDY}

To establish any kind of stratigraphic relationships, the trace element chemistry should be completed on Eagle Creek Formation samples from the Washington side of the Columbia River. Furthermore, there are exposures of the Eagle Creek Formation in the Clackamas River area. These deposits should be analyzed and compared to the northern exposures of the formation.

The strikes and dips obtained in this study (see Plate 
I) seem to suggest that the source area for the Eagle Creek Formation is to the north. However, the only known possible source to the north, the Skamania Volcanic Series, can be eliminated. If one looks southward, the Little Butte Volcanic Series presents another possibility. Figure 25 showed that there is some overlap of $\mathrm{TiO}_{2}$ and $\mathrm{P}_{2} \mathrm{O}_{5}$ concentrations with the Eagle Creek Formation. The northernmost exposures of the Little Butte Volcanic Series should be compared to both the Clackamas River and Columbia River Gorge exposures of the Eagle Creek Formation using trace element geochemistry. 


\section{REFERENCES CITED}

Al1en, J.E., 1932, Contributions to the structure, stratgraphy, and paleontology of the lower Columbia River Gorge: M. A. thesis (unpublished), Univ. of Oregon, Eugene, $96 \mathrm{p}$. , 1979, The magnificent gateway: A layman's guide to the geology of the Columbia River Gorge: Forest Grove, Oreg., Timber Press, $144 \mathrm{p}$.

Armstrong, R.L., 1978, Cenozoic history of the U.S. Cordillera from 1 at 42 to $49 \mathrm{~N}$, in Robert B. Smith and Gordon P. Eaton, eds., Geological Society of America Memoir 152, p. 265-282.

Barnes, F.F., and Butler, W., 1930, The structure and stratigraphy of the Columbia River Gorge and Cascade Mountains in the vicinity of Mount Hood: M.S. thesis (unpublished), Univ. of Oregon, Eugene, 73 p.

Chaney, R. W., 1918, Ecological significance of the Eagle Creek flora of the Columbia River Gorge: Jour. Geology, v. 26, pp. 577-592.

1959, Miocene floras of the Columbia Plateau: Carnegie Inst. Wash., Pub. 617.

Ewart, A., 1982, The mineralogy and petrology of TertiaryRecent orogenic volcanic rocks: with special reference to the andesitic-basaltic compositional range, in R.S. Thorpe, ed., Andesites: orogenic andesites and related rocks: Chichester, England, John Wiley \& Sons, pp. 25-95.

Farooqui, S.M., Beaulieu, J.D., Bunker, R.C., Stensland, D.E., and Thoms, R.E., 1981, Dalles Group: Neogene formations overlying the Columbia River Basalt Group in north-central Oregon: Oregon Geology, v. 43, no. $10, \mathrm{p} . \quad 131-140$.

Flanagan, F.J., 1976, Descriptions and analyses of eight new U.S.G.S. rock standards: U.S. Geol. Survey Prof. Paper $840,192 \mathrm{p}$. 
Gannett, M.W., 1982, A geochemical study of the Rhododendron and the Dalles Formations in the area of Mount Hood, Oregon: M.S. Thesis (unpublished), Portland State University, Portland, $70 \mathrm{p}$.

Gordon, G.E., Randle, K., Goles, G.G., Corliss, J.B., Beeson, M.H., Oxley, S.S., 1968, Instrumental activation analysis of standard rocks with high resolution gamma-ray detectors: Geochim. et Cosmochim. Acta, v. 32, no. 4, pp. 369-396.

Hammond, P.E., 1979, A tectonic model for evolution of the Cascade Range, in J.M. Armentrout, M.R. Cole, H. TerBest, Jr., eds., Cenozoic paleogeography of the western United States, Los Angeles: Society of Economic Paleontologists and Mineralogists, pp. $219-237$.

King, P.B., 1977, The evolution of North America: Princeton, Princeton University Press, 197 p.

Le Bas, M.J., Le Maitre, R.W., Streckeisen, A., Zanettin, B., 1986, A chemical classification of volcanic rocks based on total alkali-silica diagram: Jour. Petrol., v. 27, part 3, pp. 745-750.

Mckee, E.H., Swanson, D.A., and Wright, T.L., 1977, Duration and volume of Columbia River Basalt volcanism, Washington, Oregon, and Idaho [abs.]: Geological Society of America Abstracts with Programs, v. 9, no. 4, p. 463-464.

Peck, D.L., Griggs, A.B., Schlicker, H.G., Wells, F.G., Dole, H.M., 1964, Geology of the central and northern parts of the Western Cascade Range in Oregon: U.S Geological Survey Prof. Paper 449, 56 p.

Phillips, W.M., Korosec, M.A., Schasse, H.W., Anderson, J.L., Hagen, R.A., 1986, K-Ar ages of volcanic rocks in southwest Washington: Isochron/West, no. 47, pp. $18-24$.

Sherrod, D.R., 1986, Geology, petrology, and volcanic history of a portion of of the Cascade Range between latitudes $43^{\circ}-44^{\circ} \mathrm{N}$, central oregon, U.S.A.: PhD Dissertation (unpublished), University of California, Santa Barbara, $320 \mathrm{p}$. 
Tolan, T. L., 1982, The stratigraphic relationships of the Columbia River Basalt Group in the Lower Columbia River Gorge of Oregon and Washington: M.S. thesis (unpublished), Portland State University, Portland, $137 \mathrm{p}$.

Tolan, T.L., Beeson, M.H., and Vogt, B.F., 1984, Exploring the Neogene history of the Columbia River: Discussion and geologic field trip guide to the Columbia River Gorge: Oregon Geology, v. 46, no. 8, p. 87-97.

Williams, I. A., 1916, The Columbia River Gorge: its geologic history interpreted from the Columbia River Highway, Oregon: Bur. Mines and Geol., Min. Res. of Oregon, v. 2, no. 3, 130 p.

Wise, W. S., 1961, The geology and mineralogy of the Wind River Area, Washington: PhD dissertation (unpublished), Johns Hopkins University, Baltimore, $258 \mathrm{p}$. 


\section{APPENDTX A}

\section{HAND SAMPLE DESCRIPTIONS}

RC 1

RC 2

RC 3

$\mathrm{RC} 4$

RC 5

$\mathrm{RC} 6$

RC 7

RC 8

RC 9
Light gray, fine-to coarse-grained, fairly well indurated volcaniclastic sandstone. 1-3 mm andesitic clasts in a plagioclase, hornblende, and clay matrix.

Grayish black, massive, phyric hornblende pyroxene plagioclase andesite clast.

Brown, matrix-supported pebble conglomerate with angular to subrounded $1-30 \mathrm{~mm}$ andesitic and pumiceous clasts in a volcaniclastic matrix of plagioclase and hornblende crystals.

Whitish gray, massive, phyric hornblende plagioclase andesite with clay alteration.

Dark gray, friable vesicular barded glassy pyroxene plagioclase welded tuff clast.

Light gray volcaniclastic matrix-supported conglomerate containing angular to subrounded $1-15$ $\mathrm{mm}$ andesitic and pumiceous clasts in a plagioclase and clay matrix.

Medium brown, very coarse-grained clastsupported sandstone/conglomerate containing 1-15 mm (rarely $10 \mathrm{~mm}$ ) angular to subrounded andesitic clasts.

Brown, fine- to coarse-grained silty volcaniclastic sandstone containing 1-3 mm rock fragments, wood fragments, and plagioclase and hornblende crystals.

Yellow-tan, fine-to coarse-grained volcaniclastic sandstone containing $1-10 \mathrm{~mm}$ pumiceous, andesitic, and possibly basaltic clasts in a glassy/clay matrix containing plagioclase and hornblende crystals and rare wood fragments. Some limonite present.

RC 10 Light brown, fine-to coarse-grained, silty 
volcaniclastic sandstone containing plagioclase crystals and plant debris.

RC 11 Dark gray-black phyric hornblende pyroxene plagioclase andesite with epidotization of plagioclase.

RC 12 Dark gray-black vesicular coarsely phyric hornblende andesite clast with clay alteration and/or zeolitization.

RC 13 Black glassy phyric pyroxene plagioclase basalt clast.

MCC 25 Light gray, fine-grained, slightly laminated volcaniclastic sandstone with iron-staining along fracture planes. Mostly plagioclase, rare microscopic ferromagnesian minerals and pumiceous rock fragments in a clayey matrix.

EC 15 Gray, coarse-grained, slightly laminated volcaniclastic sandstone with abundant limonite.

Mostly plagioclase crystals, some hornblende, rare tuff clasts up to $3 \mathrm{~cm}$ in diameter. Abundant wood fragments.

TC 7 Gray, coarse-grained volcaniclastic sandstone. Mostly plagioclase crystals, some hornblende and carbonaceous material in a clayey matrix. Some 1 imonite present.

TC 6 Brown and black silicified tree. Structures still visible.

EC 16 Light brown, friable volcaniclastic sandstone. Most 1 y plagioclase crystals, common microscopic ferromagnesian minerals and andesitic rock fragments. Yellow-brown clay coatings on grains.

EC 17 Brown-gray, friable, coarse-grained pebbly volcaniclastic sandstone. Common plagioclase crystals. Andesitic rock fragments up to $2 \mathrm{~cm}$ in diameter and altered pumiceous clasts in a fine-grained clayey matrix with ferromagnesian minerals.

EC 18 Light gray, friable, coarse-grained, pebbly volcaniclastic sandstone. Mostly plagioclase and some hornblende crystals in a fine-grained, iron-stained matrix. Common andesitic and pumiceous clasts up to $3 \mathrm{~cm}$ in diameter. 
EC 19

EC 20

EC 21

EC 22

EC 23

EC 24

EC 25

EC 26
Light brown, coarse-grained, pebbly volcaniclastic sandstone. Mostly plagioclase and some hornblende crystals in a clayey matrix. Common angular andesitic and altered pumiceous clasts up to $2 \mathrm{~cm}$ in diameter. Rare carbonized plant material.

Light brown, friable, matrix-supported pebble conglomerate. Angular andesitic and altered pumiceous clasts up to $5 \mathrm{~cm}$ in diameter. Matrix mostly plagioclase and hornblende crystals and brown clay grain coatings. Some limonite present.

Olive brown, coarse-grained pebbly volcaniclastic sandstone. Mostly plagioclase, some hornblende crystals in a fine-grained clayey matrix. Angular andesitic pebbles up to $3 \mathrm{~cm}$ in diameter.

Light gray, friable, coarse-grained pebbly volcaniclastic sandstone. Mostly clay, plagioclase crystals, rock fragments, and rare hornblende crystals. Andesitic and altered pumiceous clasts up to $3 \mathrm{~cm}$ in diameter. Limonite coatings especially on clast/matrix interfaces. Common carbonized wood fragments.

Brown, friable, coarse-grained pebbly volcaniclastic sandstone. Mostly plagioclase crystals, common hornblende in a fine-grained matrix with some brown clay grain coatings. Andesitic clasts up to $4 \mathrm{~cm}$ in diameter. Altered pumiceous clasts up to $5 \mathrm{~mm}$ in diameter.

Orange-brown, friable, matrix-supported conglomerate. Matrix mostly plagioclase and hornblende crystals and andesitic and pumiceous rock fragments. Andesitic clasts up to $7 \mathrm{~cm}$ in diameter. Limonite along fracture surfaces and clast/ matrix interfaces.

Olive brown, friable, coarse-grained, pebbly volcaniclastic sandstone. Matrix mostly plagioclase, ferromagnesian minerals, and clay. Weathered andesitic clasts up to $4 \mathrm{~cm}$ in diameter. Black ferruginous coatings.

Light brown, slightly friable, medium- to coarse-grained volcaniclastic sandstone. Mostly plagioclase crystals, common hornblende. Fine-grained matrix. Some yellow-brown clay. 
Rare andesitic rock fragments.

EC 27 Olive brown, friable, coarse-grained volcaniclastic sandstone. Mostly plagioclase crystals, some hornblende and andesitic rock fragments. Limonite stained grains and grain coatings.

EC 28

Dark tan, medium-grained volcaniclastic sandstone. Mostly plagioclase crystals, common hornblende. Orange and black ferruginous staining common on fracture surfaces. Common carbonized plant material.

EC 29

Brown, friable, coarse-grained volcaniclastic sandstone. Mostly plagioclase crystals, common hornblende. Fine-grained matrix containing brown clay.

EC 30

Very light gray, medium-grained volcaniclastic sandstone. Mostly plagioclase crystals, some hornblende. Matrix altered to clay. Common limonite. Some secondary calcite. Rare carbonized wood fragments.

MCC 13 Olive brown, slightly friable, coarse-grained volcaniclastic sandstone. Mostly plagioclase crystals, common andesitic rock fragments up to $5 \mathrm{~mm}$ in diameter, some hornblende. Possible altered pumice fragments.

MCC 29 Gray, friable, coarse-grained, pebbly volcaniclastic sandstone. Mostly plagioclase and hornblende crystals, some clay. Angular andesitic pebbles up to $5 \mathrm{~cm}$ in diameter.

TC 8

Very light gray, massive, medium-grained volcanclastic sandstone. Mostly plagioclase, some hornblende crystals. Rare pumiceous and andesitic rock fragments. White botryoidal opaline interstitial fillings and grain coatings.

TC 9 Olive brown, fraible, coarse-grained, pebbly volcaniclastic sandstone. Mostly plagioclase, some hornblende crystals. Brown clay coatings. Numerous angular andesitic pebbles up to $10 \mathrm{~mm}$ in diameter.

TC 10 01ive brown, massive, coarse-grained volcaniclastic sandstone. Mostly plagioclase crystals, common hornblende and andesitic rock fragments up to $3 \mathrm{~mm}$ in diameter. Brown clay coatings. 
TC 11

MCC 11 Brown-gray, massive, medium-grained volcani-

0live brown, massive, coarse-grained volcaniclastic sandstone. Mostly plagioclase crystals, rare ferromagnesian minerals. Fine-grained matrix. Common brown clay coatings. clastic sandstone. Mostly plagioclase crystals, ferromagnesian minerals, and rock fragments.

Common rounded pumice fragments altered to clay. Fine-grained matrix.

MCC 22 Brown-gray, massive, medium-grained volcaniclastic sandstone. Mostly plagioclase, common microscopic ferromagnesian minerals. Andesitic clasts up to $3 \mathrm{~cm}$ in diameter. Abundant clay. Limonite on weathered surfaces and on clast/ matrix interfaces.

TC 3 Light gray, massive, medium-grained volcaniclastic sandstone. Mostly plagioclase, abundant hornblende crystals. Common andesitic clasts up to $10 \mathrm{~mm}$ in diameter. Rare altered pumiceous grains. Common limonite. White botryoidal opaline interstitial fillings and grain coatings.

EC 4 Light gray, massive, matrix-supported volcanic conglomerate. Andesitic clasts ranging up to $5 \mathrm{~cm}$ in diameter. Matrix mostly plagioclase crystals, common hornblende, and clay.

SKV-1 Black vitric phyric plagioclase andesite with limonite-coated fracture surfaces.

SKV-2 Dark gray vitric phyric plagioclase dacite with limonite-coated fracture surfaces.

EC 12 Blocky-fractured, coarse-grained volcaniclastic sandstone completely altered to white waxytextured clay. Rock fragments still recognizeable but composition unknown (presume andesitic and pumiceous fragments). Limonite on all fracture surfaces. 
TRACE ELEMENT DATA

\begin{tabular}{|c|c|c|c|c|c|c|c|c|c|c|c|c|c|c|c|c|}
\hline SAMFLE & N & a & k & & So & & $\mathrm{Cr}$ & & $\mathrm{Fe}$ & & $C_{0}$ & & In & n & As & \\
\hline $\mathrm{RC} 1$ & 3.68 & \pm .01 & .9 & \pm .2 & 11.10 & $\pm \cdot 10$ & 43. \pm & b. & 4.69 & \pm .07 & $14.0 \pm$ & .5 & .00 & \pm .00 & $.00:$ & \pm .00 \\
\hline $\mathrm{RC2}$ & 3.76 & .01 & 1.1 & .2 & 12.32 & .08 & 20. & 3. & 3.71 & .04 & 9.0 & .3 & .00 & .00 & .00 & .00 \\
\hline R3 & 3.12 & .01 & .77 & .16 & 12.00 & .09 & 38. & 5. & 4.97 & .06 & 16.0 & .4 & .00 & .00 & .00 & .00 \\
\hline $\mathrm{RC4}$ & 3.72 & .01 & .75 & .19 & 14.74 & .09 & 79. & 10. & 4.03 & .05 & 8.9 & .3 & .00 & .00 & .00 & .00 \\
\hline RC5 & 1.26 & .00 & .52 & .06 & 9.90 & .07 & 30. & 4. & 4,44 & .05 & 14.5 & .4 & 78. & 8. & .00 & .00 \\
\hline RC6 & 3.29 & .01 & $.8 B$ & .16 & 11.02 & .08 & 43. & $b$ & 5,44 & .06 & 22.5 & .6 & .000 & .00 & .00 & .00 \\
\hline $\mathrm{R}[\mathrm{7}$ & 3.40 & .01 & 1.06 & .18 & 12.88 & .09 & 42. & $b$ & 6.00 & .08 & 27.0 & .7 & .00 & .09 & .00 & .00 \\
\hline $\mathrm{RCB}$ & 3.45 & .01 & .8 & .2 & 10.35 & .00 & 43. & 6. & 5.13 & .06 & 11.0 & .4 & .00 & .00 & .00 & .00 \\
\hline $\mathrm{RCO}$ & 3.25 & .01 & 1.17 & .16 & 9.98 & .07 & 29. & 4. & 2.75 & .04 & 25.0 & .6 & .00 & .00 & 100 & 20. \\
\hline RCio & 2.80 & .01 & .78 & .18 & 12.78 & .09 & 40. & 5. & 5.22 & .07 & 23.5 & .6 & .00 & .00 & 130. & 3n. \\
\hline RC11 & 3.43 & .01 & 1.67 & .18 & 15.24 & .09 & 48. & $b$. & 4.47 & .05 & 10.1 & $\therefore$ & .00 & .00 & 70. & 20. \\
\hline RC12 & 4.07 & .01 & 1.4 & .2 & 16.36 & .10 & 75. & 9. & 4.87 & .06 & 15.2 & .5 & .00 & .00 & .00 & .00 \\
\hline RCIS & 3.39 & .01 & 1.4 & .2 & 19.17 & .11 & 25. & 4. & 7.05 & .08 & 15.3 & .4 & .00 & .00 & 80. & 20. \\
\hline$A 6 V 1-3$ & 4.29 & .02 & 3.4 & .3 & 13.29 & .11 & 14. & 3. & 6.72 & .08 & 14.0 & .5 & .00 & .00 & .00 & .00 \\
\hline $65 P 1-3$ & 2.64 & .01 & 5.0 & .4 & 6.09 & .06 & 17. & 3. & 3.86 & .05 & 5.4 &.$j$ & .00 & .00 & .00 & .00 \\
\hline AGVI-9 & 4.26 & .01 & 2.9 & .2 & 13.40 & .08 & 12. & 2. & 6.76 & .06 & 14.1 & .4 & .00 & .60 & .00 & .00 \\
\hline $65 P 1-9$ & 2.61 & .01 & 5.4 & .3 & 6.05 & .04 & 16. & 2. & 3.84 & .04 & 5.78 & .18 & 84. & 7. & .00 & .00 \\
\hline
\end{tabular}

$\mathrm{Na}, \mathrm{K}, \mathrm{Fe}$ in oxide weight 8 , all others in ppm.

Uncertainties given as one standard deviation based on counting statistics.

*As calculated based on arbitrary concentration in RC 9 .

MCC and RC 1 from McCord Creek

$\mathrm{TC}$ and $\mathrm{RC} 6$ from Tanner Creek

EC and RC 7-RCl3 from Eagle Creek 


\begin{tabular}{|c|c|c|c|c|c|c|c|c|c|c|c|c|c|c|c|c|c|}
\hline SAMPLE & Rb & & Sr & & Cs & \# & $B 2$ & & & La & & CR & & Nd & & Sa & \\
\hline $\mathrm{RCI}$ & $.00 \pm$ & \pm .00 & 460. \pm & 120. & 100. \pm & 30. & 280. \pm & 60. & 14.0 & \pm & .6 & $28.7 \pm$ & 1.2 & 15. \pm & 3. & $3.43 \pm$ & .08 \\
\hline $\mathrm{RC2}$ & .00 & .00 & 570. & 100 & 70. & 20. & 280. & 40. & 13.4 & & .4 & 26.8 & .9 & 17. & 3. & 3.56 & .06 \\
\hline RJ & .00 & .00 & 480. & 100. & 70. & 20. & 320. & 50. & 12.0 & & .4 & 26.1 & .9 & 14. & 3. & 2.99 & .06 \\
\hline RC4 & .00 & .00 & 490. & 110. & 80. & 30. & 280. & 50. & 18.4 & & .5 & 40.6 & 1.2 & 24. & 3. & 5.03 & .07 \\
\hline $\mathrm{RCS}$ & 21. & 5. & 380. & 80. & 100. & 20. & 240. & 50. & 9.6 & & .3 & 26.8 & .9 & 17. & 2. & 2.33 & .04 \\
\hline $\mathrm{RC6}$ & .00 & .00 & 530. & 110. & 90. & 30. & 330. & 50. & 12.6 & & .4 & 25.2 & 1.0 & 16. & 3. & 2.89 & .06 \\
\hline $\mathrm{RC7}$ & .00 & .00 & .00 & .00 & .00 & .00 & 260. & 60. & 12.7 & & .5 & 28.1 & 1.2 & 18. & 3. & 3.04 & .07 \\
\hline RCB & .00 & .00 & 370. & 100. & 80. & 20. & 400. & 50. & 11.0 & & .4 & 21.4 & 1.0 & 12. & 3. & 2.52 & .06 \\
\hline RC9 & 20. & 5. & 400. & 80. & 70. & 20. & 420. & 10. & 12.6 & & .4 & 22.7 &.$\theta$ & 17. & 2. & 2.46 & .05 \\
\hline $\mathrm{RC} 10$ & .00 & .00 & 450. & 120. & 90. & 30. & 280. & 60. & 12.7 & & .5 & 28.0 & 1.2 & 17. & 4. & 3.06 & .06 \\
\hline RCII & 31. & 6. & 540. & 100. & 100 & 20. & 310. & 50. & 12.1 & & .4 & 25.7 & .9 & 20. & 3. & 3.32 & .05 \\
\hline $\mathrm{RCI} 2$ & .00 & .00 & .00 & .00 & .00 & .00 & 400 & 60. & 18.9 & & .6 & 39.6 & 1.3 & 22. & 4. & 4.69 & .08 \\
\hline $\mathrm{RC} 13$ & 30. & 8. & 550. & 120. & 110 & 30. & 290. & 90. & 14.0 & & .4 & 32.3 & 1.2 & 25. & 4. & 4.44 & .07 \\
\hline AEVI -3 & 67. & 10. & 740. & 150. & .00 & .00 & 1350. & 90. & 34.7 & & .8 & 62.0 & 1.8 & 35. & 5. & 5.74 & .09 \\
\hline 65P1-3 & 240. & 20. & .00 & .00 & .00 & .00 & 1200. & 70. & 155. & & 2. & 345. & 7. & 229. & 17. & 24.5 & .2 \\
\hline A6V1-9 & 67. & 7. & 660. & 100 & .00 & .00 & 1210. & 60. & 35.0 & & .6 & 63.0 & 1.6 & 39. & 4. & 5.90 & .07 \\
\hline $6 S P 1-9$ & 245. & 19. & 220. & 50. & .00 & .00 & 1180. & 60. & 156. & & 2. & 337. & 6. & 237. & 16. & 24.0 & .2 \\
\hline
\end{tabular}

\# Cs calculated based on arbitrary concentration in RC 1 


\begin{tabular}{|c|c|c|c|c|c|c|c|c|c|c|c|c|c|c|}
\hline SAMPLE & E & & TI & & $Y b$ & & Lu & & $\mathrm{Hf}$ & & $\mathrm{Ta}$ & & Th & \\
\hline $\mathrm{RCl}$ & 1.18 & \pm .05 & .32 & \pm .06 & $1.4 \pm$ & .4 & $.13 \pm$ & .03 & $3.5 \pm$ & .2 & $.76 \pm$ & .09 & $2.28 \pm$ & $=.16$ \\
\hline AC2 & 1.16 & .04 & .39 & .05 & 1.2 & .2 & .15 & .02 & 3.09 & .18 & .40 & .06 & 2.05 & .13 \\
\hline RJ & .98 & .04 & .29 & .05 & .7 & .2 & .14 & .03 & 3.2 & .2 & .45 & .07 & 2.55 & .13 \\
\hline $\mathrm{RCA}$ & 1.34 & .05 & .51 & .06 & 1.3 & .3 & .23 & .03 & 2.8 & .2 & .47 & $.0 \mathrm{~B}$ & 1.66 & .15 \\
\hline $\mathrm{RC5}$ & .86 & .03 & .34 & .05 & .9 & .2 & .17 & .02 & 3.09 & .18 & .52 & .07 & 2.28 & .11 \\
\hline $\mathrm{RC} b$ & .90 & .04 & .24 & .06 & .00 & .00 & .10 & .03 & 3.2 & .2 & .57 & .08 & 2.21 & .14 \\
\hline $\mathrm{ACT}$ & .96 & .04 & .51 & .07 & .8 & .2 & .18 & .03 & 3.4 & .2 & .75 & .10 & 2.43 & .16 \\
\hline $\mathrm{RCB}$ & .84 & .04 & .39 & .06 & .00 & .00 & .14 & .03 & 3.0 & .2 & .57 & .08 & 1.98 & .16 \\
\hline $\mathrm{RCO}$ & .82 & .03 & .27 & .04 & .8 & .2 & .12 & .02 & 3.30 & .19 & .69 & .07 & 2.00 & .11 \\
\hline $\mathrm{RC} 10$ & .98 & .05 & .50 & .07 & .8 & .2 & .23 & .04 & 3.7 & .2 & .55 & .09 & 4.13 & .18 \\
\hline RCII & .96 & .04 & .37 & .05 & .79 & .19 & .19 & .03 & 3.8 & .2 & .42 & .07 & 3.58 & .16 \\
\hline $\mathrm{RC} 12$ & 1.25 & .05 & .67 & .07 & 1.2 & .3 & .18 & .04 & 5.7 & .3 & .87 & .10 & 5.2 & .2 \\
\hline $\mathrm{R}[\mathrm{CIJ}$ & 1.19 & .05 & .54 & .08 & 1.4 & .3 & .25 & .04 & 4.1 & .3 & .35 & .08 & 4.15 & .19 \\
\hline$A 6 V_{1-3}$ & 1.80 & .07 & .65 & .08 & 1.9 & .3 & .27 & .04 & 5.4 & .3 & .86 & .13 & 6.0 & .2 \\
\hline GSPI-3 & 1.82 & .07 & .00 & .00 & 1.8 & .4 & .22 & .04 & 14.1 & .6 & .00 & .00 & 97. & 2. \\
\hline AGVI-9 & 1.70 & .05 & .70 & .06 & 1.7 & .3 & .28 & .03 & 5.2 & .3 & .90 & .09 & 6.41 & .18 \\
\hline 65P1-9 & 1.57 & .05 & .00 & .00 & 1.9 & .3 & .20 & .02 & 12.3 & .5 & .76 & .08 & 93.5 & 1.9 \\
\hline
\end{tabular}




\begin{tabular}{|c|c|c|c|c|c|c|c|c|c|c|c|c|c|c|c|c|c|}
\hline SAMPLE & n & & $k$ & & Sc & & & $\mathrm{Cr}$ & & $\mathrm{Fe}$ & & $C_{0}$ & & As & & $\mathrm{Rb}$ & \\
\hline HCC 25-A & 3.28 & \pm .01 & $.00 \pm$ & .00 & $11.65 \pm$ & .08 & 40. & \pm & 5. & $2.88 \pm$ & .05 & $20.1 \pm$ & .5 & $3.3 \pm$ & .8 & $.00 \pm$ & .00 \\
\hline $\operatorname{NCC} 25-B$ & 3.05 & .01 & .00 & .00 & 9.85 & .08 & 28. & & 4. & 2.96 & .05 & 19.2 & .5 & 1.9 & .5 & .00 & .00 \\
\hline HCC 25-C & 3.41 & .01 & .00 & .00 & 10.07 & .08 & 31. & & 4. & 2.92 & .05 & 12.0 & .4 & .00 & .00 & .00 & .00 \\
\hline ACC 25-D & 3.05 & .01 & .00 & .00 & 9.15 & .07 & 28. & & 4. & 2.87 & .04 & 10.8 & .3 & .00 & .00 & .00 & .00 \\
\hline HCC $25-E$ & 3.25 & .01 & .00 & .00 & 10.65 & .08 & 37. & & 5. & 2.96 & .05 & 17.2 & .5 & .00 & .00 & .00 & .00 \\
\hline MCC 25-F & 3.07 & .01 & .00 & .00 & 9.30 & .07 & 24. & & 4. & 2.62 & .05 & 18.8 & .5 & 1.3 & .4 & .00 & .00 \\
\hline ИСС 25-6 & 3.24 & .01 & .00 & .00 & 8.16 & .06 & 25. & & 4. & 2.71 & .04 & 13.5 & .4 & 1.7 & .5 & .00 & .00 \\
\hline HCC 25-H & 2.77 & .01 & .00 & .00 & 10.10 & .08 & 30. & & 4. & 3.18 & .05 & 20.1 & .6 & 1.7 & .5 & .00 & .00 \\
\hline ncc 25-I & 3.13 & .01 & .00 & .00 & 9.99 & $.0 B$ & 28. & & 4. & 2.77 & .05 & 14.0 & .4 & .00 & .00 & .00 & .00 \\
\hline $\operatorname{nCC} 25-\mathrm{J}$ & 3.35 & .01 & .00 & .00 & 10.00 & .08 & 28. & & 4. & 2.77 & .05 & 20.2 & .6 & 1.7 & .5 & .00 & .00 \\
\hline EC 15-A & 3.54 & .01 & .7 & .2 & 11.07 & .08 & 66. & & 8. & 4.32 & .06 & 8.9 & .3 & 2.2 & .6 & .00 & .00 \\
\hline EC $15-B$ & 3.35 & .01 & .8 & .2 & 9.94 & .08 & 65. & & B. & 4.44 & .06 & 8.4 & .3 & 5.3 & 1.2 & .00 & .00 \\
\hline EC $15-C$ & 3.83 & .01 & .7 & .2 & 11.72 & .09 & 68. & & 9. & 4.17 & .06 & B.9 & .3 & 3.3 & . 8 & .00 & .00 \\
\hline EC 15-D & 3.45 & .01 & .00 & .00 & 10.75 & .09 & 54. & & 7. & 3.27 & .05 & 7.6 & .3 & .00 & .00 & .00 & .00 \\
\hline EC $15-E$ & 3.32 & .01 & .7 & .2 & 11.48 & .08 & 66. & & B. & 4.87 & .07 & B.7 & .3 & 7.6 & 1.6 & .00 & .00 \\
\hline EC $15-F$ & 3.68 & .01 & .7 & .2 & 10.74 & .09 & 56. & & 7. & 3.25 & .05 & 7.2 & .3 & .00 & .00 & .00 & .00 \\
\hline EC 15-6 & 3.68 & .01 & .8 & .2 & 10.67 & .09 & 49. & & 7. & 3.34 & .05 & 7.4 & .3 & .00 & .00 & 19. & 6. \\
\hline EC $15-H$ & 3.40 & .01 & .00 & .00 & 11.31 & .09 & 57. & & 7. & 4.24 & .06 & 8.3 & .3 & 2.5 & .7 & .00 & .00 \\
\hline EC $15-1$ & 3.24 & .01 & .00 & .00 & 11.27 & .08 & 60. & & 8. & 3.64 & .05 & B.6 & .3 & .00 & .00 & .00 & .00 \\
\hline EC 15-J] & 3.54 & .01 & .00 & .00 & 11.14 & .09 & 60. & & 8. & 3.47 & .05 & 8.8 & .3 & .00 & .00 & .00 & .00 \\
\hline
\end{tabular}




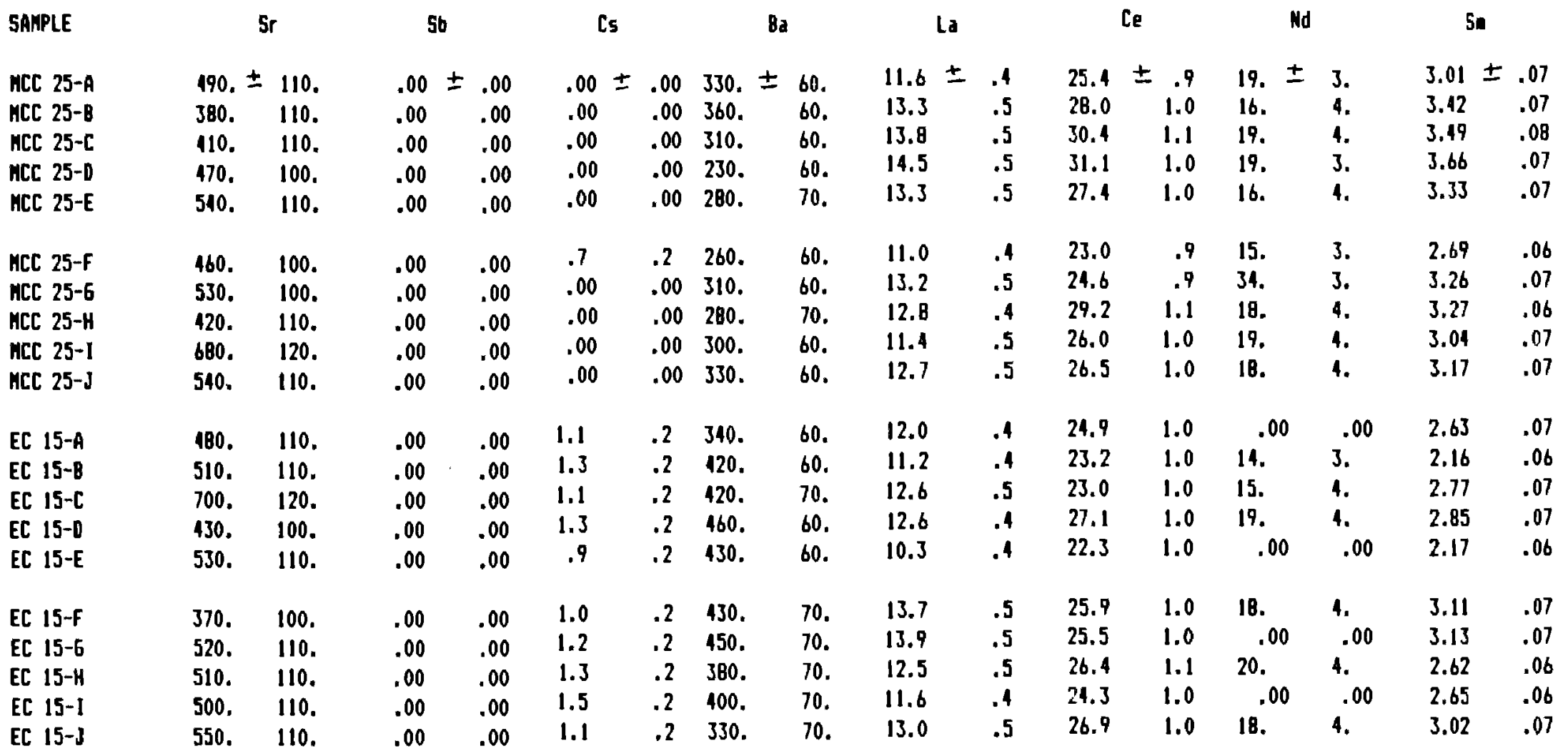




\begin{tabular}{|c|c|c|c|c|c|c|c|c|c|c|c|c|c|c|c|}
\hline SAMPLE & & u & Ib & & $y_{b}$ & & Lu & & & Hf & & $T_{d}$ & & Th & \\
\hline HCC 25-A & 1.24 & \pm .05 & $.36 \pm$ & .05 & $1.1 \pm$ & .3 & $.14 \pm$ & .03 & 3.7 & \pm & .2 & $.72 \pm$ & .07 & $2.34 \pm$ & .15 \\
\hline НCC 25-B & 1.26 & .05 & .40 & .06 & 1.1 & .3 & .15 & .03 & 4.2 & & .2 & .70 & .08 & 2.94 & .17 \\
\hline $\operatorname{MCC} 25-\mathrm{C}$ & 1.41 & .06 & .34 & .06 & 1.1 & .2 & .00 & .00 & 3.8 & & .2 & .73 & .08 & 3.05 & .17 \\
\hline HCC 25-D & 1.14 & .04 & .36 & .05 & .00 & .00 & .14 & .03 & 3.9 & & .2 & .69 & .07 & 3.05 & .15 \\
\hline MCC 25-E & 1.36 & .06 & .35 & .06 & .8 & .2 & .15 & .04 & 4.0 & & .2 & .75 & .09 & 2.9 & .2 \\
\hline $\operatorname{MCC} 25-\mathrm{F}$ & 1.23 & .05 & .35 & .05 & .74 & .19 & .00 & .00 & 3.9 & & .2 & .71 & .07 & 2.60 & .15 \\
\hline HCC 25-6 & 1.18 & .05 & .32 & .06 & .00 & .00 & .18 & .04 & 3.8 & & .2 & .78 & .07 & 2.83 & .15 \\
\hline МСС 25-H & 1.28 & .06 & .43 & .07 & 1.2 & .3 & .13 & .04 & 4.3 & & .3 & .78 & .10 & 2.95 & .18 \\
\hline НсC 25-I & 1.40 & .05 & .37 & .06 & .8 & .2 & .15 & .04 & 4.0 & & .3 & .70 & .08 & 2.61 & .16 \\
\hline MCC $25-\mathrm{J}$ & 1.27 & .05 & .33 & .05 & .00 & .00 & .13 & .04 & 3.8 & & .2 & .78 & .08 & 2.89 & .17 \\
\hline EC 15-A & 1.11 & .05 & .25 & .05 & .00 & .00 & .00 & .00 & 2.9 & & .2 & .52 & .05 & 1.79 & .15 \\
\hline EC $15-B$ & 1.08 & .05 & .32 & .05 & .00 & .00 & .00 & .00 & 2.6 & & .2 & .48 & .06 & 1.47 & .14 \\
\hline EC $15-C$ & 1.01 & .05 & .23 & .06 & .00 & .00 & .00 & .00 & 3.4 & & .2 & .66 & .07 & 2.08 & .16 \\
\hline EC 15-D & 1.08 & .05 & .23 & .05 & .00 & .00 & .11 & .03 & 2.8 & & .2 & .44 & .07 & 1.93 & .14 \\
\hline EC $15-E$ & .97 & .04 & .18 & .05 & .00 & .00 & .13 & .04 & 3.1 & & .2 & .60 & .07 & 1.50 & .14 \\
\hline EC $15-F$ & 1.03 & .05 & .20 & .05 & .00 & .00 & .00 & .00 & 2.7 & & .2 & .61 & .08 & 1.85 & .15 \\
\hline EC $15-6$ & 1.00 & .05 & .36 & .06 & .00 & .00 & .00 & .00 & 3.1 & & .2 & .63 & .07 & 2.06 & .16 \\
\hline EC 15-H & 1.10 & .05 & .24 & .05 & .00 & .00 & .00 & .00 & 3.1 & & .2 & $.5 \theta$ & .07 & 1.79 & .15 \\
\hline EC 15-I & 1.03 & .05 & .33 & .05 & .00 & .00 & .14 & .04 & 2.8 & & .2 & .55 & .07 & 1.86 & .15 \\
\hline EC $15-J$ & 1.15 & .05 & .35 & .05 & .9 & .3 & .00 & .00 & 2.7 & & .2 & .56 & .07 & 1.74 & .16 \\
\hline
\end{tabular}




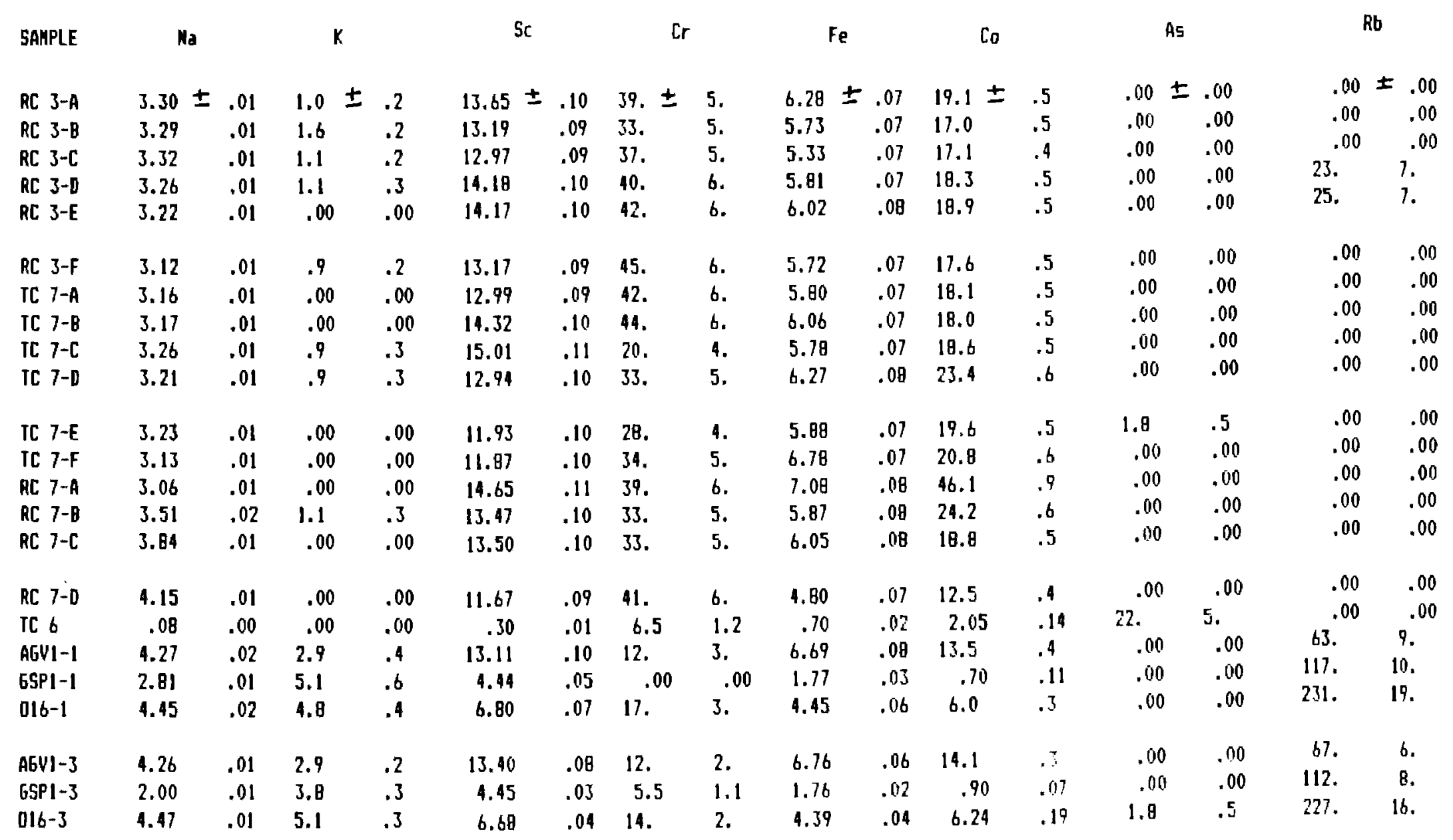




\begin{tabular}{|c|c|c|c|c|c|c|c|c|c|c|c|c|c|c|c|c|}
\hline SAMFLE & $5 r$ & & $5 b$ & & Cs & & $\mathrm{Ba}$ & & La & & Ce & & No & & Sn & \\
\hline RC J-A & 390. \pm & 120. & $.00 \pm$ & .00 & $.00 \pm$ & .00 & 400. \pm & 90. & $12.7 \pm$ & .5 & $31.5 \pm$ & 1.2 & $20 . \pm$ & 4. & $3.24 \pm$ & .07 \\
\hline RC 3-B & 580. & 120. & .00 & .00 & .00 & .00 & 320. & 70. & 16.1 & .5 & 33.5 & 1.2 & 21. & 4. & 3.73 & .07 \\
\hline RC J-C & 420. & 110. & .00 & .00 & .00 & .00 & 360. & 70. & 13.5 & .5 & 26.9 & 1.1 & 13 & 4. & 3.47 & .07 \\
\hline RC 3-D & .00 & .00 & .00 & .00 & .9 & .3 & .00 & .00 & 13.6 & .5 & 30.1 & 1.2 & 18. & 4. & 3.49 & .07 \\
\hline RC $3-E$ & 660. & 130. & .00 & .00 & 1.3 & .3 & 360. & 80. & 12.8 & .5 & 31.0 & 1.3 & 20. & 5. & 3.37 & .07 \\
\hline RC 3-F & 660. & 130. & .00 & .00 & 1.4 & .2 & 310 & 80. & 12.3 & .5 & 28.9 & 1.1 & 18. & 4. & 3.12 & .07 \\
\hline TC 7-A & .00 & .00 & .00 & .00 & .00 & .00 & .00 & .00 & 13.6 & .5 & 29.4 & 1.2 & .00 & .00 & 3.06 & .07 \\
\hline TC $7-B$ & 580. & 130. & .00 & .00 & .00 & .00 & .00 & .00 & 12.5 & .4 & 24.0 & 1.1 & 19. & 4. & 3.17 & .07 \\
\hline TC 7-C & 460. & 130. & .00 & .00 & .00 & .00 & .00 & .00 & 10.2 & .5 & 21.5 & 1.2 & 21. & 5. & 2.82 & .07 \\
\hline IC 7-D & 570. & 130. & .00 & .00 & .00 & .00 & .00 & .00 & 10.0 & .4 & 21.3 & 1.2 & .00 & .00 & 2.64 & .06 \\
\hline TC 7-E & 640. & 130. & .00 & .00 & .00 & .00 & .00 & .00 & 12.0 & .5 & 26.1 & 1.2 & 15. & 4. & 2.88 & .07 \\
\hline TC 7-F & 450. & 120. & .00 & .00 & .9 & .2 & .00 & .00 & 11.2 & .4 & 24.5 & 1.2 & .00 & .00 & 2.71 & .06 \\
\hline RC 7-A & .00 & .00 & .00 & .00 & .00 & .00 & .00 & .00 & 10.2 & .4 & 20.6 & 1.1 & .00 & .00 & 2.51 & .06 \\
\hline$R C 7-B$ & .00 & .00 & .00 & .00 & .00 & .00 & 340. & 80. & 13.5 & .5 & 27.7 & 1.2 & 14. & 4. & 3.33 & .07 \\
\hline RC 7-C & .00 & .00 & .00 & .00 & .00 & .00 & 430 & 80. & 16.4 & .5 & 35.5 & 1.7 & 23. & 5. & 4.04 & .08 \\
\hline RC 7-D & 480. & 120. & .00 & .00 & .00 & .00 & 460. & 80. & 15.8 & .5 & 33.5 & 1.3 & 22. & 5. & 3.92 & .08 \\
\hline TC 6 & .00 & .00 & 2.7 & .4 & .00 & .00 & .00 & .00 & 6.6 & .2 & 13.7 & .5 & 7.1 & 1.6 & 1.33 & .03 \\
\hline AGV1-3 & 500. & 130. & 10.2 & 1.1 & .00 & .00 & 1240. & 120 & 36.0 & .8 & 61.0 & 1.6 & 35. & 6. & 6.07 & .10 \\
\hline $0-16-3$ & .00 & .00 & 1.6 & .5 & 3.3 & .2 & 700. & 60. & 173. & 2. & 73.5 & 1.5 & 41. & 5. & 27.2 & .3 \\
\hline GSP1-3 & .00 & .00 & 9.3 & 1.1 & .00 & .00 & 1490. & 100. & 37.6 & .8 & 398. & 6. & 280. & 20. & 6.34 & .10 \\
\hline AGVI-9 & 660. & 90. & 4.5 & .4 & .00 & .00 & 1210. & 70. & 35.0 & .5 & 63.0 & 1.2 & 39. & 4. & 5.90 & .07 \\
\hline $0-16-9$ & .00 & .00 & 1.29 & .16 & 3.50 & .15 & 670. & 40. & 151.4 & 1.8 & 70.1 & 1.2 & 39. & 4. & 24.8 & .2 \\
\hline $65 P 1-9$ & .00 & .00 & 4.9 & .4 & .00 & .00 & 1410. & 70. & 37.3 & .6 & 401. & 6. & 280. & 20. & 6.39 & .07 \\
\hline
\end{tabular}




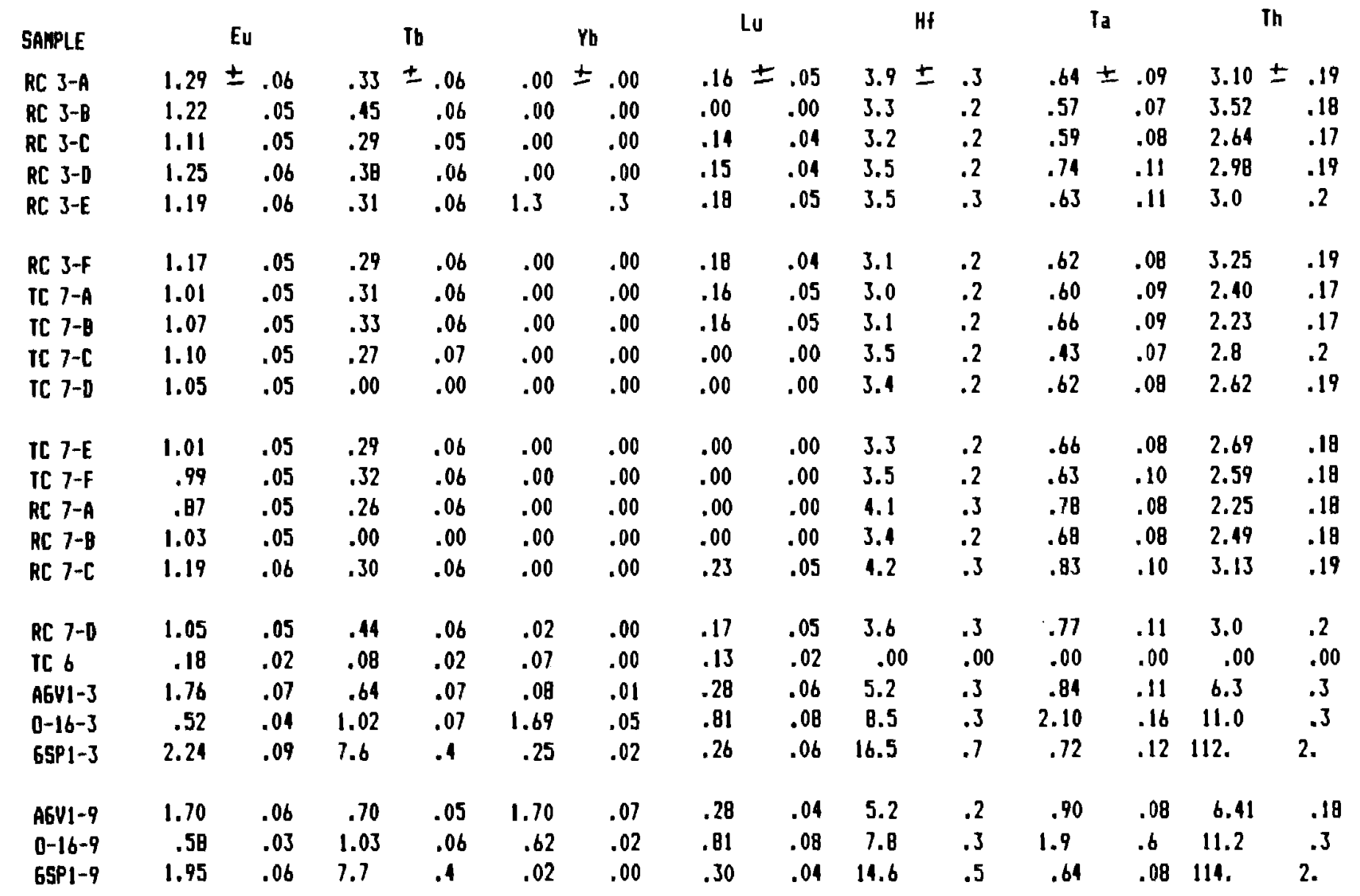




\begin{tabular}{|c|c|c|c|c|c|c|c|c|c|c|c|c|c|c|c|c|c|c|c|}
\hline SAMPLE & Ma & & K & & & c & & & Cr & & $\mathrm{Fe}$ & & & Co & & Rb & & $\mathrm{Sr}$ & \\
\hline EC 16 & $3.37 \pm$ & .01 & $2.2 \pm$ & .3 & 11.71 & \pm & .10 & 34. & \pm & 5. & $4.50 \pm$ & .07 & 12.4 & \pm & .4 & 33. \pm & 9. & $.00 \pm$ & .00 \\
\hline EC 17 & 3.54 & .01 & 1.3 & .3 & 11.24 & & .10 & 33. & & 5. & 5.06 & .08 & 21.5 & & .6 & .00 & .00 & 470 & 150. \\
\hline EC 18 & 3.79 & .01 & 1.2 & .3 & 11.82 & & .10 & 29. & & 4. & 3.08 & .06 & $23 . \theta$ & & .7 & .00 & .00 & 490. & 150. \\
\hline EC 19 & 3.73 & .01 & 1.5 & .3 & 11.83 & & .09 & 28. & & 4. & 2.65 & .05 & 17.7 & & .5 & .00 & .00 & 490. & 140. \\
\hline EC 20 & 3.38 & .01 & .00 & .00 & 12.31 & & .10 & 28. & & 4. & 5.92 & .08 & 18.6 & & .6 & .00 & .00 & 550. & 150. \\
\hline EC 21 & 3.37 & .01 & 1.2 & .3 & 11.79 & & .09 & 36. & & 5. & 4.10 & .06 & 16.1 & & .5 & 25. & 8. & 450. & 140. \\
\hline EC 22 & 3.48 & .02 & .00 & .00 & 15.30 & & .12 & 40. & & 6. & 4.24 & .07 & 15.8 & & .5 & .00 & .00 & .00 & .00 \\
\hline EC 23 & 3.35 & .01 & .00 & .00 & 12.55 & & .10 & 41. & & 6. & 6.12 & .08 & 17.1 & & .5 & .00 & .00 & 460. & 140. \\
\hline EC 24 & 3.11 & .01 & .00 & .00 & 12.56 & & .10 & 40. & & 6. & 7.53 & .09 & 20.8 & & .6 & .00 & .00 & 490. & 150. \\
\hline EC 25 & 2.98 & .01 & .00 & .00 & 12.91 & & .10 & 40. & & b. & 5.04 & .08 & 17.0 & & .6 & .00 & .00 & .00 & .00 \\
\hline EC 26 & 3.52 & .02 & .00 & .00 & 8.87 & & .08 & 19. & & 3. & 4.14 & .07 & 17.8 & & .6 & .00 & .00 & .00 & .00 \\
\hline EC 27 & 3.24 & .01 & .00 & .00 & 14.60 & & .10 & 54. & & 7. & 6.13 & .08 & 18.9 & & .6 & .00 & .00 & .00 & .00 \\
\hline EC 28 & 3.32 & .01 & .00 & .00 & 10.09 & & .08 & 34. & & 5. & 4.18 & .07 & 11.9 & & .4 & .00 & .00 & 530. & 140. \\
\hline EC 29 & 3.64 & .01 & .00 & .00 & 11.58 & & .09 & 38. & & 5. & 5.65 & .08 & 14.1 & & .5 & .00 & .00 & 540. & 150. \\
\hline EC 30 & 3.53 & .02 & .00 & .00 & 11.20 & & .10 & 24. & & 4. & 3.21 & .06 & 14.0 & & .5 & .00 & .00 & .00 & .00 \\
\hline MCC IJ-A & 3.22 & .01 & .00 & .00 & 12.46 & & .10 & 45. & & b. & 5.98 & $.0 \mathrm{~B}$ & 16.3 & & .5 & .00 & .00 & .00 & .00 \\
\hline NCC 13-B & 3.27 & .01 & .00 & .00 & 12.75 & & .10 & 43. & & b. & 5.85 & $.0 \mathrm{~B}$ & 15.7 & & .5 & .00 & .00 & .00 & .00 \\
\hline MCL I]-[ & 2.98 & .01 & .00 & .00 & 12.07 & & .10 & 41. & & 6. & 5.82 & .08 & 15.0 & & .5 & .00 & .00 & .00 & .00 \\
\hline МсC 13-0 & 3.31 & .01 & .00 & .00 & 11.62 & & .09 & 43. & & b. & 5.65 & .08 & 15.1 & & .5 & .00 & .00 & 550. & 150. \\
\hline НCC 13-E & 3.14 & .02 & .00 & .00 & 12.40 & & .10 & 12. & & 6. & 5.91 & .09 & 16.1 & & .5 & .00 & .00 & .00 & .00 \\
\hline
\end{tabular}




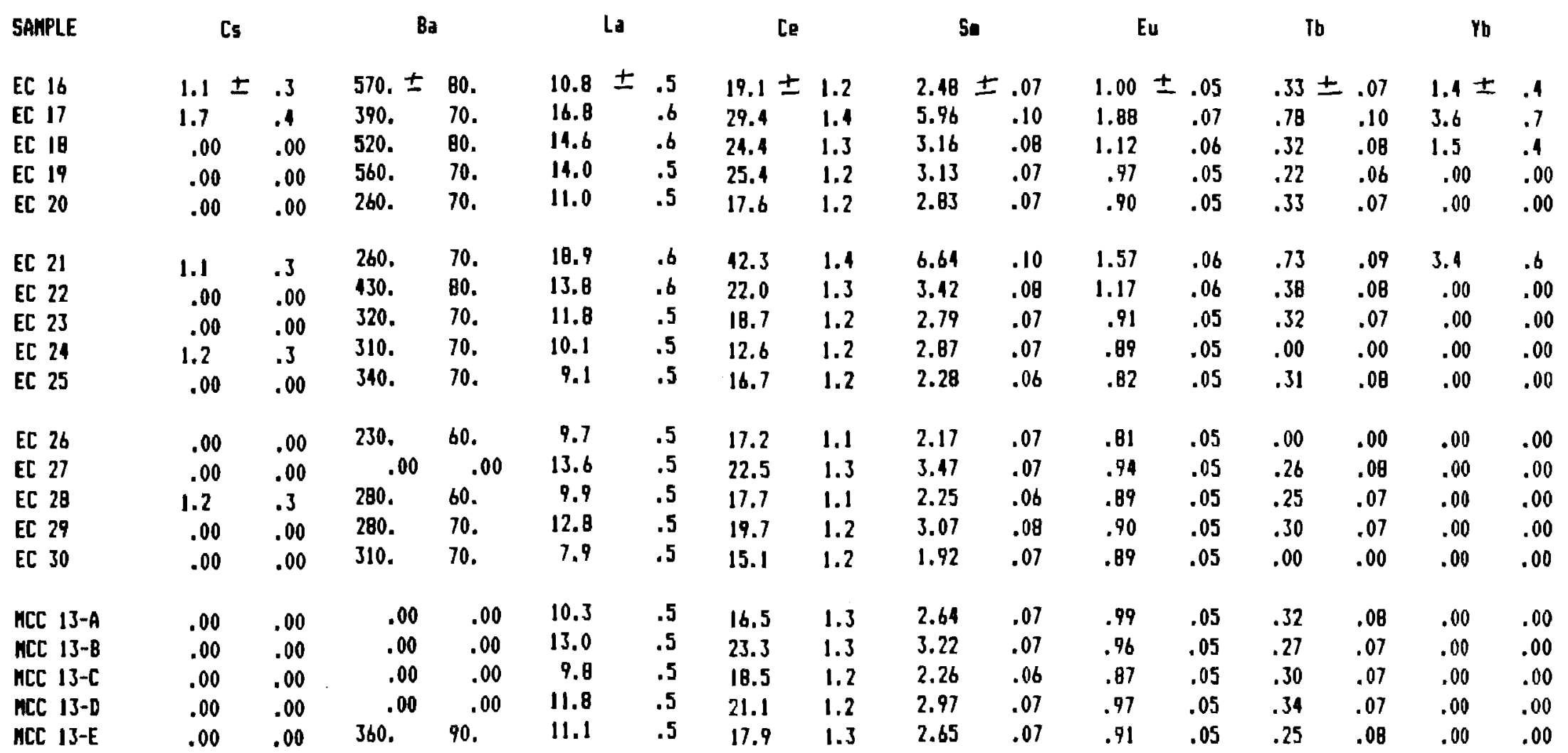




\begin{tabular}{|c|c|c|c|c|c|c|c|c|c|}
\hline SAMPLE & L & & & Hf & & $\mathrm{Ta}$ & & Th & \\
\hline EC 16 & .17 & \pm .05 & 3.6 & \pm & .3 & $.74 \pm$ & .10 & $2.3 \pm$ & .2 \\
\hline EC 17 & .56 & $.0 B$ & 3.7 & & .3 & .50 & .10 & 2.5 & .2 \\
\hline EC 18 & .16 & .05 & 3.8 & & .3 & .78 & .11 & 2.5 & .2 \\
\hline EC 19 & .16 & .04 & 3.5 & & .2 & .60 & .09 & 2.42 & .18 \\
\hline EC 20 & .00 & .00 & 3.4 & & .2 & .58 & .09 & 2.32 & .19 \\
\hline EC 21 & .47 & .07 & 3.1 & & .2 & .48 & .10 & 1.71 & .18 \\
\hline EC 22 & .16 & .05 & 3.6 & & .3 & .54 & .10 & 2.8 & .2 \\
\hline EC 23 & .00 & .00 & 3.1 & & .2 & .52 & .09 & 2.04 & .19 \\
\hline EC 24 & .00 & .00 & 2.8 & & .2 & .69 & .10 & 1.9 & .2 \\
\hline EC 25 & .00 & .00 & 3.1 & & .2 & .64 & .10 & 2.1 & .2 \\
\hline EC 26 & .00 & .00 & 2.6 & & .2 & .53 & .08 & 1.76 & .17 \\
\hline EC 27 & .00 & .00 & 2.4 & & .2 & .62 & .10 & 1.67 & .19 \\
\hline EC 28 & .16 & .04 & 2.8 & & .2 & .57 & .08 & 1.79 & .17 \\
\hline EC 29 & .00 & .00 & 3.2 & & .2 & .61 & .10 & 1.76 & .18 \\
\hline EC 30 & .18 & .05 & 3.2 & & .2 & .70 & .11 & 2.9 & .2 \\
\hline HCC 13-A & .00 & .00 & 3.2 & & .3 & .79 & .11 & 2.3 & .2 \\
\hline $\operatorname{AcC} 13-8$ & .20 & .05 & 3.3 & & .2 & .74 & .10 & 2.2 & .2 \\
\hline $\operatorname{MCC} 13-\mathrm{C}$ & .00 & .00 & 2.8 & & .2 & .64 & .09 & 2.28 & .19 \\
\hline $\operatorname{MCC} 13-1)$ & .24 & .05 & 3.1 & & .2 & .71 & .10 & 2.28 & .19 \\
\hline HCC 13-E & .00 & .00 & 3.4 & & .3 & .77 & .11 & 2.3 & .2 \\
\hline
\end{tabular}




\begin{tabular}{|c|c|c|c|c|c|c|c|c|c|c|c|c|c|c|c|c|c|}
\hline SAMPLE & $\mathrm{Na}$ & a & $k$ & & $5 c$ & & Cr & & $\mathrm{Fe}$ & & & Co & & Rb & & Sr & \\
\hline ACC 29-A & 3.62 & \pm .02 & $.00 \pm$ & .00 & 13.46 & \pm .11 & 55. \pm & $\theta$. & 5.30 & \pm & .08 & $23.0 \pm$ & .7 & $.00 \pm$ & .00 & 650. \pm & 170. \\
\hline NCC 29-B & 3.45 & .02 & .00 & .00 & 12.48 & .10 & 52. & 7. & 5.18 & & .07 & 21.9 & .6 & .00 & .00 & 440. & 140. \\
\hline HCC $29-C$ & 3.25 & .02 & .00 & .00 & 13.81 & .11 & 45. & 7. & 6.41 & & .09 & 31.3 & .8 & .00 & .00 & 750. & 180. \\
\hline ACC 29-D & 3.50 & .02 & .00 & .00 & 14.30 & .10 & 54. & 7. & 5.38 & & .07 & 23.6 & .7 & .00 & .00 & .00 & .00 \\
\hline HCC 29-E & 3.63 & .02 & .00 & .00 & 12.74 & .10 & 46. & 7. & 5.41 & & .08 & 25.0 & .7 & .00 & .00 & 500. & 160. \\
\hline TC 8 & 3.25 & .02 & .00 & .00 & 12.94 & .10 & 31. & 5. & 5.95 & & .08 & 18.0 & .6 & .00 & .00 & 690. & 170. \\
\hline TC 9 & 3.18 & .02 & .00 & .00 & 12.93 & .10 & 38. & 5. & 6.01 & & .09 & 17.1 & .5 & .00 & .00 & 540. & 160. \\
\hline TC 10 & 3.23 & .02 & .00 & .00 & 10.97 & .09 & 29. & 4. & 5.14 & & .08 & 14.1 & .5 & .00 & .00 & 590. & 150. \\
\hline TC 11 & 3.32 & .02 & .00 & .00 & 12.39 & .10 & 36. & 5. & 5.47 & &. $\mathrm{OB}$ & 18.8 & .6 & .00 & .00 & 430. & 140. \\
\hline nec 11 & 2.90 & .02 & .00 & .00 & 12.84 & .10 & 31. & 5. & 5.12 & & .07 & 16.7 & .5 & .00 & .00 & .00 & .00 \\
\hline MCC 22 & 3.27 & .02 & .00 & .00 & 14.42 & .12 & 25. & 4. & 5.57 & & .08 & 14.7 & .5 & .00 & .00 & .00 & .00 \\
\hline IC 3 & 3.01 & .02 & .00 & .00 & 16.98 & .12 & 60. & 8. & 8.15 & & .10 & 24.9 & .7 & .00 & .00 & .00 & .00 \\
\hline EC 4 & 3.06 & .02 & .00 & .00 & 11.27 & .09 & 35. & 5. & 5.63 & & .08 & 15.0 & .5 & .00 & .00 & .00 & .00 \\
\hline $5 K V-1$ & 4.22 & .02 & .00 & .00 & 15.74 & .11 & .00 & .00 & 6.14 & & .09 & 9.5 & .4 & 66. & 12. & .00 & .00 \\
\hline $5 K V-2$ & 3.17 & .02 & .00 & .00 & 24.70 & .16 & 96. & 13 & 8.26 & & .10 & 32.4 & .8 & 38. & 11. & .00 & .00 \\
\hline EC $12-A$ & .32 & .01 & .00 & .00 & 24.24 & .15 & 73. & 10. & 4.84 & & .08 & 2.3 & .2 & .00 & .00 & .00 & .00 \\
\hline EC $12-B$ & .31 & .01 & .00 & .00 & 22.99 & .15 & 82. & 11. & 5.20 & & .08 & 2.3 & .3 & .00 & .00 & .00 & .00 \\
\hline A5V1-1 & 4.25 & .03 & 3.0 & 8 & 13.07 & .11 & .00 & .00 & 6.74 & & .09 & 13.9 & .5 & 68. & 13. & 930. & 200. \\
\hline $016-1$ & 4.41 & .02 & 5.0 & .8 & 4.29 & .05 & 6.3 & 1.8 & 1.65 & & .04 & .84 & .14 & 124. & 13. & .00 & .00 \\
\hline 65P1-1 & 2.74 & .02 & 6.1 & .9 & 6.47 & .07 & 14. & 3. & 4.19 & & .07 & 5.8 & .3 & 290. & 30. & .00 & .00 \\
\hline A6VI-3 & 4.26 & .01 & 2.9 & .3 & 13.40 & .08 & 12. & 2. & 6.76 & & .07 & 14.1 & .4 & 67. & 8. & 660. & 120. \\
\hline $016-3$ & 4.45 & .01 & 5.2 & .5 & 4.33 & .03 & 5.1 & 1.2 & 1.70 & & .03 & .85 & .08 & 130. & 12. & .00 & .00 \\
\hline 65P1-3 & 2.76 & .01 & 5.6 & .6 & 6.66 & .05 & 14. & 2. & 4.29 & & .05 & 6.3 & .2 & 280. & 30. & .00 & .00 \\
\hline
\end{tabular}




\begin{tabular}{|c|c|c|c|c|c|c|c|c|c|c|c|c|c|c|c|c|}
\hline SAMPLE & & C5 & $\mathrm{Ba}$ & & La & & & Ce & So & & Eu & & Tb & & Yb & \\
\hline MCC 27-A & 2.0 & \pm .4 & .001 & \pm .00 & $11.0 \pm$ & .5 & 19.2 & \pm 1.3 & 3.13 & \pm .08 & $1.03 \pm$ & .05 & $.00 \pm$ & .00 & $.00 \pm$ & .00 \\
\hline ИСС 29-B & .00 & .00 & 300. & 70. & 10.3 & .5 & 17.5 & 1.2 & 2.92 & .07 & .96 & .05 & .00 & .00 & 1.4 & .4 \\
\hline KCC 29-C & .00 & .00 & .00 & .00 & 10.5 & .5 & 17.0 & 1,3 & 2.99 & .07 & .94 & .05 & .00 & .00 & .010 & .00 \\
\hline MCC 29-D & 6.9 & .5 & .00 & .00 & 10.5 & .5 & 17.9 & 1.3 & 3.25 & .07 & 1.07 & .05 & .31 & .08 & .00 & .00 \\
\hline НCC 29-E & .00 & .00 & 300. & 80. & 10.4 & .5 & 17.7 & 1.3 & 3.12 & $.0 B$ & .92 & .06 & .00 & .00 & .00 & .00 \\
\hline TC 8 & .00 & .00 & 310. & 90. & 11.1 & .5 & 19.0 & 1.3 & 3.15 & .07 & .82 & .05 & .00 & .00 & .00 & .00 \\
\hline IC 9 & .00 & .00 & 310. & 80. & 16.6 & .6 & 28.0 & 1.4 & 4.09 & .08 & .96 & .05 & .33 & .07 & .00 & .00 \\
\hline IC 10 & .00 & .00 & 410. & 70. & 11.7 & .5 & 17.3 & 1.2 & 2.72 & .07 & .90 & .05 & .28 & .07 & .00 & .00 \\
\hline TC 11 & .00 & .00 & 320. & 90. & 13.0 & .5 & 19.5 & 1.2 & 3.36 & .07 & .93 & .05 & .26 & .07 & .00 & .00 \\
\hline ACC 11 & 1.3 & .3 & .00 & .00 & 11.4 & .5 & 18.5 & 1.2 & 3.23 & .07 & .91 & .05 & .34 & .07 & 1.2 & .4 \\
\hline MCC 21 & .00 & .00 & 310. & 90. & 12.7 & .5 & 22.0 & 1.4 & 3.72 & .09 & 1.30 & .06 & .40 & .09 & 1.5 & .5 \\
\hline IC 3 & 1.3 & .4 & 350. & 90. & 9.7 & .5 & 12.1 & 1.3 & 2.80 & .07 & .87 & .05 & .35 & .08 & .00 & .00 \\
\hline EC 4 & 1.4 & .3 & .00 & .00 & 14.0 & .5 & 24.6 & 1.3 & 3.03 & .07 & .99 & .05 & .38 & .07 & .00 & .00 \\
\hline $5 K V-1$ & 3.2 & .4 & 530. & 90. & 21.0 & .7 & 42.7 & 1.7 & 7.81 & .12 & 1.65 & .07 & 1.07 & .12 & 5.6 & 1.0 \\
\hline $5 K V-2$ & 7.3 & .6 & 430. & 100. & 19.0 & .6 & 28.9 & 1.6 & 5.79 & .10 & 1.32 & .06 & .67 & .11 & 2.5 & .6 \\
\hline EC $12-A$ & .00 & .00 & .00 & .00 & 14.8 & .5 & 21.1 & 1.5 & 1.62 & .05 & .34 & .05 & .54 & .10 & .00 & .00 \\
\hline EC $12-B$ & 1.7 & .4 & .00 & .00 & 12.6 & .5 & 16.9 & 1.4 & 1.52 & .05 & .39 & .05 & .51 & .10 & .00 & .00 \\
\hline AGVI-3 & 3.7 & .4 & 1160 & 110. & 34.8 & .9 & 57.7 & 1.9 & 5.92 & .11 & 1.58 & .07 & .68 & .10 & 2.1 & .6 \\
\hline $016-3$ & 3.5 & .3 & 550. & 60. & 38.1 & .9 & 71.5 & 1.8 & 6.11 & .11 & .46 & .04 & 1.25 & .11 & 6.1 & 1.0 \\
\hline $65 P 1-3$ & $3 . \mathrm{B}$ & .4 & 1260 & 100. & 170. & 3. & 398. & 7. & 25.0 & .3 & 2.21 & .09 & 7.6 & .6 & 2.3 & .6 \\
\hline AEV1-9 & 4.1 & .3 & 1210 & BO. & 35.0 & .6 & 63.0 & 1.4 & 5.90 & .08 & 1.70 & .05 & .70 & .07 & 1.7 & .4 \\
\hline $016-9$ & 3.5 & .2 & 640. & 40. & 37.6 & .6 & 75.1 & 1.5 & $6.2 \theta$ & .08 & .50 & .03 & 1.12 & .09 & 6.0 & .9 \\
\hline $65 P 1-9$ & 3.6 & .2 & 1310 & 70. & 172. & 2. & 413. & 7. & 25.5 & .3 & 2.16 & .07 & 7.9 & .6 & 2.4 & .5 \\
\hline
\end{tabular}




\begin{tabular}{|c|c|c|c|c|c|c|c|c|c|}
\hline SAMPLE & & Lu & & HF & & & $\mathrm{Ta}$ & Th & \\
\hline MCC 29-A & .00 & \pm .00 & 3.1 & \pm & .3 & .74 & \pm .11 & $1.8 \pm$ & .2 \\
\hline MCC 29-B & .00 & .00 & 2.9 & & .2 & .52 & .09 & 1.72 & .19 \\
\hline КСC 29-C & .00 & .00 & 3.1 & & .3 & .71 & .11 & 1.8 & .2 \\
\hline MCC 29-D & .18 & .05 & 2.9 & & .2 & .64 & .10 & 1.8 & .2 \\
\hline HCC 29-E & .22 & .06 & 3.3 & & .3 & .71 & .11 & 2.0 & .2 \\
\hline TC $\theta$ & .00 & .00 & 2.9 & & .2 & .57 & .10 & 2.3 & .2 \\
\hline TC 9 & .00 & .00 & 3.2 & & .2 & .69 & .10 & 2.7 & .2 \\
\hline IC 10 & .00 & .00 & 2.7 & & .2 & .82 & .10 & 2.4 & .2 \\
\hline TC 11 & .16 & .05 & 2.6 & & .2 & .56 & .09 & 1.47 & .19 \\
\hline $\operatorname{Mcc} 11$ & .22 & .05 & 2.9 & & .2 & .53 & .09 & 2.11 & .19 \\
\hline HCC 22 & .20 & .06 & 4.5 & & .3 & .91 & .12 & 2.9 & .2 \\
\hline IC 3 & .24 & .06 & 3.2 & & .3 & .74 & .11 & 1.7 & .2 \\
\hline EC 4 & .00 & .00 & 3.4 & & .2 & .73 & .10 & 2.7 & .2 \\
\hline SKV-1 & .77 & .11 & 9.2 & & .4 & 1.07 & .14 & 7.4 & .3 \\
\hline $5 K V-2$ & .42 & .08 & 5.4 & & .3 & .66 & .12 & 4.1 & .3 \\
\hline EC 12-A & .00 & .00 & 5.3 & & .3 & 1.31 & .14 & 7.1 & .3 \\
\hline EC $12-B$ & .00 & .00 & 5.0 & & .3 & 1.43 & .15 & 7.0 & .3 \\
\hline A6VI-3 & .30 & .07 & 4.9 & & .3 & 1.04 & .13 & 6.0 & .3 \\
\hline $016-3$ & .77 & .10 & 7.8 & & .3 & 2.18 & .18 & 10.4 & .3 \\
\hline $65 P 1-3$ & .25 & .07 & 14.9 & & .6 & .80 & .15 & 112. & 3. \\
\hline AEV1-9 & .28 & .05 & 5.2 & & 2 & .90 & .09 & b. 4 & .2 \\
\hline $016-9$ & .85 & .10 & 7.7 & & 3 & 2.04 & .16 & 11.1 & .3 \\
\hline 65P1-9 & .30 & .05 & 15.3 & & .5 & .84 & .10 & 114. & 3. \\
\hline
\end{tabular}


APPENDIX C

NORMALIZED MAJOR ELEMENT DATA (WEIGHT \%)

\begin{tabular}{|c|c|c|c|c|}
\hline SAMPLE & $\mathrm{SiO}_{2}$ & $\mathrm{~A} 2_{2} \mathrm{O}_{3}$ & $\mathrm{TiO}_{2}$ & $\mathrm{Fe}_{2} \mathrm{O}_{3}$ \\
\hline EC $15-A$ & 67.95 & 16.10 & 1.009 & 0.832 \\
\hline EC 16 & 63.34 & 18.02 & 0.874 & 0.894 \\
\hline EC 17 & 64.85 & 18.54 & 0.893 & 1.032 \\
\hline EC 22 & 64.43 & 19.35 & 1.029 & 0.810 \\
\hline EC 25 & 62.56 & 18.33 & 0.926 & 1.038 \\
\hline MCC 13-D & 59.81 & 19.40 & 1.099 & 1.290 \\
\hline MCC $25-G$ & 63.84 & 20.73 & 0.804 & 0.576 \\
\hline MCC 29-D & 61.18 & 18.28 & 0.992 & 1.062 \\
\hline RC 3-D & 61.42 & 18.08 & 0.917 & 1.128 \\
\hline TC 7-E & 61.00 & 18.11 & 0.834 & 1.170 \\
\hline \multirow[t]{2}{*}{ RC 7} & 62.68 & 16.50 & 0.900 & 1.184 \\
\hline & $\mathrm{MgO}$ & $\mathrm{K}_{2} \mathrm{O}$ & $\mathrm{Na}_{2} \mathrm{O}$ & $\mathrm{P}_{2} \mathrm{O}$ \\
\hline EC $15-A$ & 0.93 & 0.71 & 3.62 & 0.177 \\
\hline EC 16 & 2.96 & 2.11 & 3.58 & 0.127 \\
\hline EC 17 & 0.76 & 1.34 & 3.71 & 0.172 \\
\hline EC 22 & 0.97 & 1.07 & 3.71 & 0.233 \\
\hline EC 25 & 2.81 & 0.91 & 3.50 & 0 . \\
\hline MCC 13-D & 3.13 & 0.43 & 3.45 & 0 . \\
\hline MCC $25-G$ & 1.32 & 0.46 & 3.70 & \\
\hline MCC 29-D & 3.32 & 0.85 & 3.67 & 0.192 \\
\hline $\mathrm{RC} \quad 3-\mathrm{D}$ & 3.23 & 1.04 & 3.44 & \\
\hline TC $7-E$ & 3.58 & 0.92 & 3.41 & \\
\hline RC 7 & 3.59 & 1.04 & 3.83 & 0.179 \\
\hline
\end{tabular}


APPENDIX D

XRF TRACE ELEMENTS (ppm)

\begin{tabular}{|c|c|c|c|c|c|c|c|c|c|}
\hline SAMPLE & $\mathrm{Ni}$ & $\mathrm{C}_{\mathbf{r}}$ & $\mathrm{Sc}$ & v & $\mathrm{Ba}$ & $\mathrm{Rb}$ & $\mathrm{S}_{\mathbf{r}}$ & $\mathrm{Zr}$ & Y \\
\hline EC $15-A$ & 23 & 49 & 17 & 120 & 336 & 13 & 517 & 135 & 10 \\
\hline EC 16 & 28 & 29 & 14 & 96 & 610 & 32 & 473 & 147 & 11 \\
\hline EC 17 & 33 & 27 & 15 & 112 & 325 & 24 & 437 & 152 & 58 \\
\hline $\mathrm{EC} \quad 22$ & 19 & 35 & 16 & 111 & 466 & 21 & 519 & 155 & 13 \\
\hline EC 25 & 35 & 36 & 21 & 81 & 308 & 17 & 498 & 140 & 11 \\
\hline MCC $13-D$ & 33 & 51 & 22 & 164 & 188 & 7 & 533 & 154 & 11 \\
\hline MCC $25-G$ & 29 & 27 & 16 & 73 & 273 & 10 & 578 & 161 & 11 \\
\hline MCC 29D & 43 & 48 & 20 & 122 & 254 & 28 & 502 & 136 & 11 \\
\hline $\mathrm{RC} \quad 3-\mathrm{D}$ & 37 & 34 & 19 & 110 & 279 & 22 & 54 & 144 & 11 \\
\hline $\mathrm{TC} 7-\mathrm{E}$ & 34 & 26 & 20 & 106 & 245 & 15 & 526 & 142 & 11 \\
\hline \multirow[t]{2}{*}{$\mathrm{RC} 7$} & 40 & 33 & 19 & 92 & 350 & 14 & 438 & 153 & 13 \\
\hline & $\mathrm{Nb}$ & $\mathrm{Ga}$ & $\mathrm{Cu}$ & $\mathrm{Zn}$ & & & & & \\
\hline EC $15-A$ & 10.2 & 17 & 38 & 46 & & & & & \\
\hline $\mathrm{EC} \quad 16$ & 12.4 & 20 & 65 & 76 & & & & & \\
\hline EC 17 & 11.2 & 23 & 81 & 104 & & & & & \\
\hline EC 22 & 11.1 & 25 & 86 & 72 & & & & & \\
\hline EC 25 & 11.4 & 21 & 75 & 80 & & & & & \\
\hline MCC $13-D$ & 13.0 & 21 & 66 & 82 & & & & & \\
\hline MCC $25-G$ & 12.5 & 23 & 65 & 63 & & & & & \\
\hline MCC $29-D$ & 9.8 & 21 & 73 & 75 & & & & & \\
\hline $\mathrm{RC} \quad 3-\mathrm{D}$ & 11.1 & 24 & 54 & 77 & & & & & \\
\hline TC $7-E$ & 11.0 & 17 & 65 & 78 & & & & & \\
\hline $\mathrm{RC} 7$ & 12.0 & 19 & 58 & 88 & & & & & \\
\hline
\end{tabular}




\section{APPENDIX E}

\section{THIN SECTION DESCRIPTIONS}

$\mathrm{RC} 3$

RC 5

$\mathrm{RC} 7$

$\mathrm{RC} \quad 13$

EC 15

EC 29

TC 7

MCC 13
43\% plagioclase/clay matrix, 30\% anhedral to subhedral plagioclase phenocrysts (An52), 20\% tuff clasts, $2 \%$ hornblende, $2 \%$ pyroxene, $2 \%$ opaques, $1 \%$ zeolites.

$50 \%$ dark brown glass/clay, $45 \%$ zoned anhedral to subhedral plagioclase, $5 \%$ hypersthene.

80-90\% andesite rock fragments, $19-9 \%$ anhedral to subhedral plagioclase phenocrysts and microlites, $1 \%$ hornblende, oxyhornblende, and smectite.

Smectite rims on rock fragments and phenocrysts.

60\% plagioclase microlites/microcrystalline matrix, $30 \%$ anhedral to subhedral plagioclase phenocrysts (An64), 5\% clinopyroxene with some chlorite alteration, $3 \%$ smectite, $2 \%$ opaques.

$75 \%$ crystal tuff clasts (plagioclase, hornblende and oxyhornblende), $15 \%$ anhedral to subhedral zoned plagioclase phenocrysts, 5\% hornblende, oxyhornblende, and orthopyroxene phenocrysts, $5 \%$ matrix and alteration minerals (smectite, iron oxides).

$35 \%$ plagioclase microlites/microcrystalline matrix, $30 \%$ anhedral to subhedral plagioclase phenocrysts (An 45), 25\% andesite rock fragments, $5 \%$ hornblende, $3 \%$ smectite, $2 \%$ opaques.

Slightly laminated with abundant organic material. Anhedral to subhedral plagioclase phenocrysts in a microcrysta11ine/plagioclase matrix. $50 \%$ plagioclase phenocrysts, $40 \%$ matrix, $5 \%$ andesite fragments, $1 \%$ hornblende, $1 \%$ oxyhornblende, $1 \%$ clinopyroxene, $1 \%$ organic material, $1 \%$ opaques, $<1 \%$ zeolites.

$40 \%$ microcrysta 11 ine/glass-clay matrix, $30 \%$ anhedra1 to subhedral plagioclase phenocrysts (many zoned), 25\% andesite rock fragments, $10 \%$ clinopyroxene, orthopyroxene, opaques, oxyhorn- 
blende. Smectite rims on fragments and crystals.

MCC 25 Laminated. Two discontinuous "layers" of rounded pumice fragments and tuff clasts parallel to lamination. One organic lamination. $50 \%$ anhedral plagioclase fragments, 50\% microcrystalline/clay matrix.

MCC $2950 \%$ matrix (80\% plagioclase, $15 \%$ clays, $4 \%$ hornblende, $1 \%$ pyroxene, opaques), $25 \%$ subhedral plagioclase phenocrysts $(A n 40), 25 \%$ andesite rock fragments. 


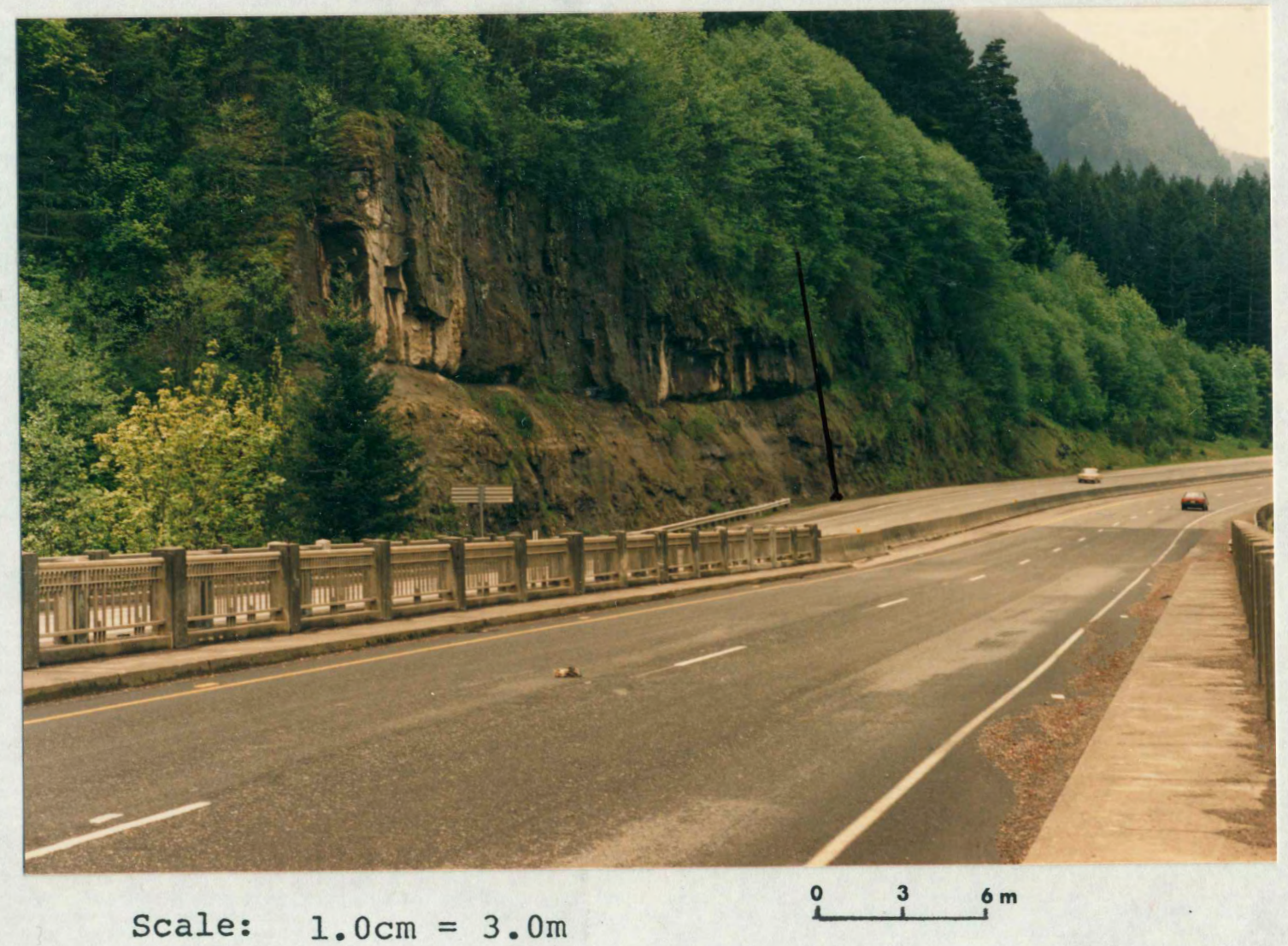

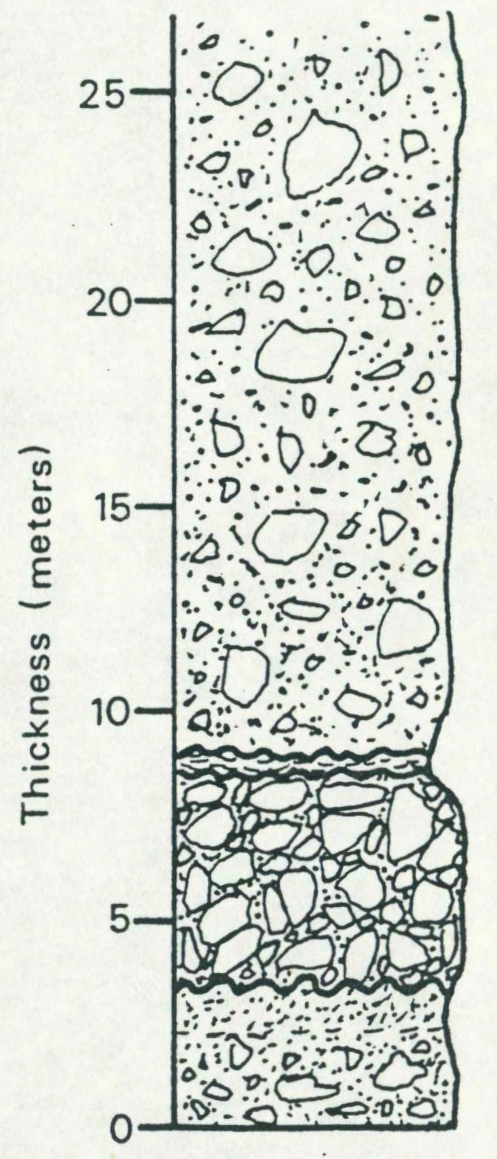

Unstratified matrix supported conglomerate

\section{Vertical scale:}

$1.27 \mathrm{~cm}=3.05 \mathrm{~m}$
Tuffaceous claystone/siltstone

Clast to matrix supported

conglomerate

Inversel.y graded from boulder

to pebble conglomerate to coarse

to medium-grained sandstone

Outcrop on west side of McCord Creek. 


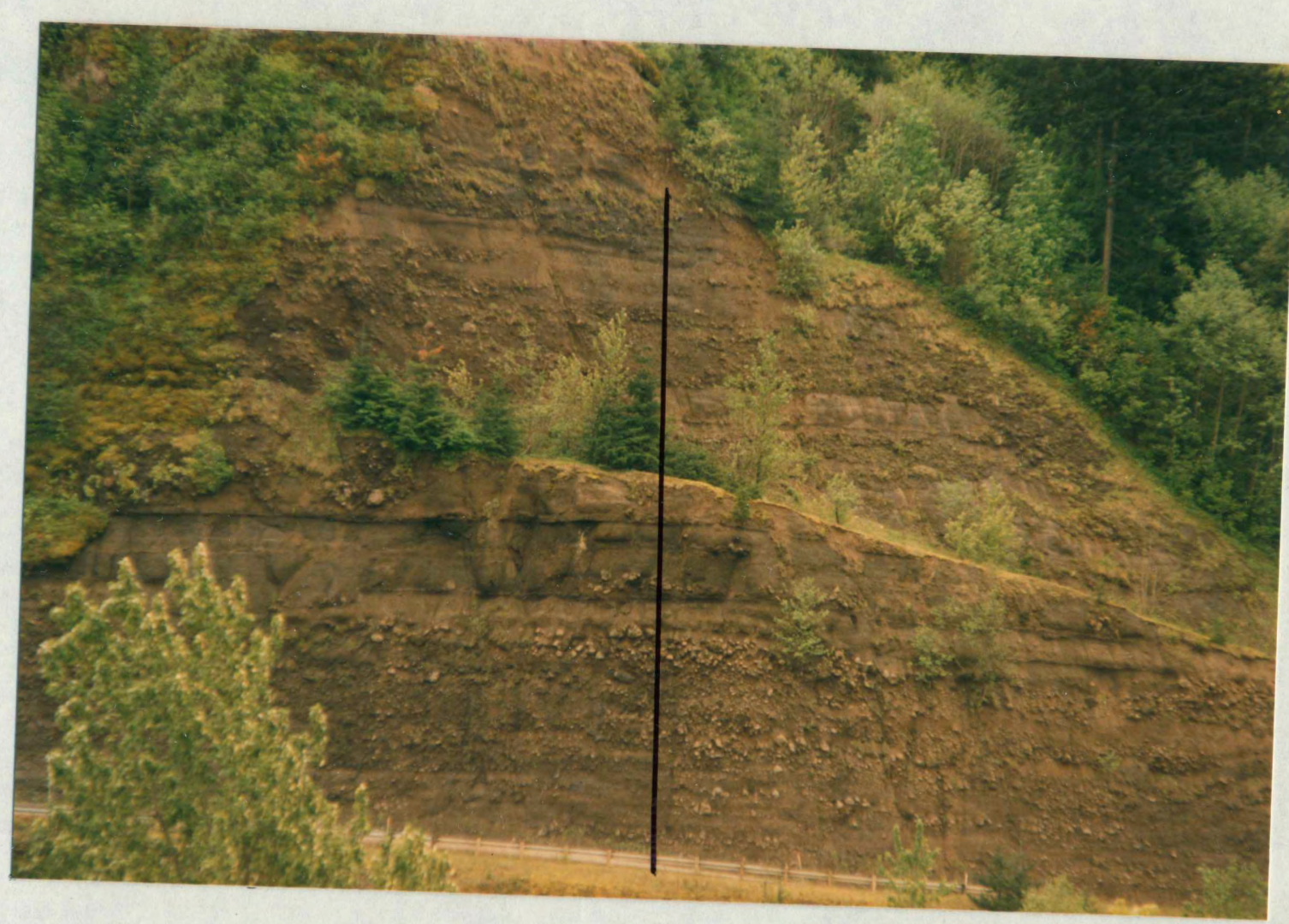

Scale: $\quad 1.52 \mathrm{~cm}=3.05 \mathrm{~m}$

$3.05 \mathrm{~m}$

exit ramp from side of Eagle Creek along

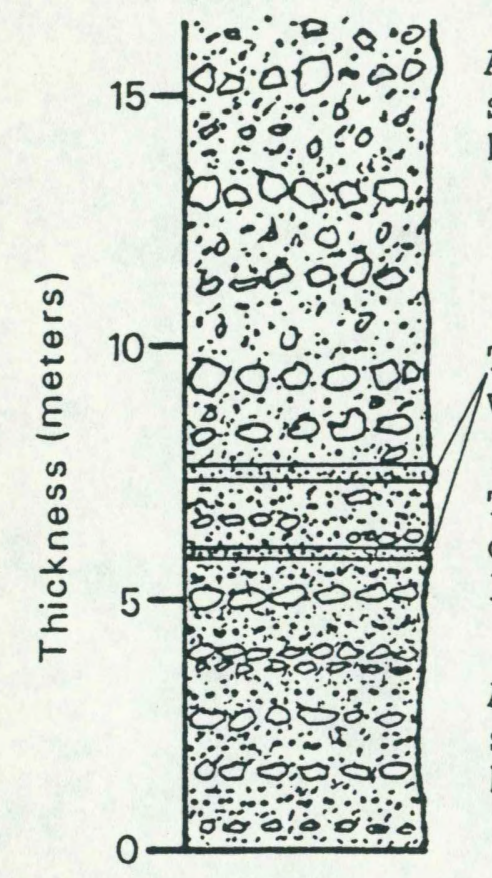

Alternating tuffaceous sandstone, pebble-, cobble-, and boulder-conglomerate layers

Tuffaceous sandy siltstone with abundant plant fossils

Tuffaceous sandstone with discontinuous cobble/boulder layers.

Alternating tuffaceous sandstone, vebble-, cobble-, and boulder-conglomerate layers

Vertical scale:

$1.52 \mathrm{~cm}=3.05 \mathrm{~m}$ 


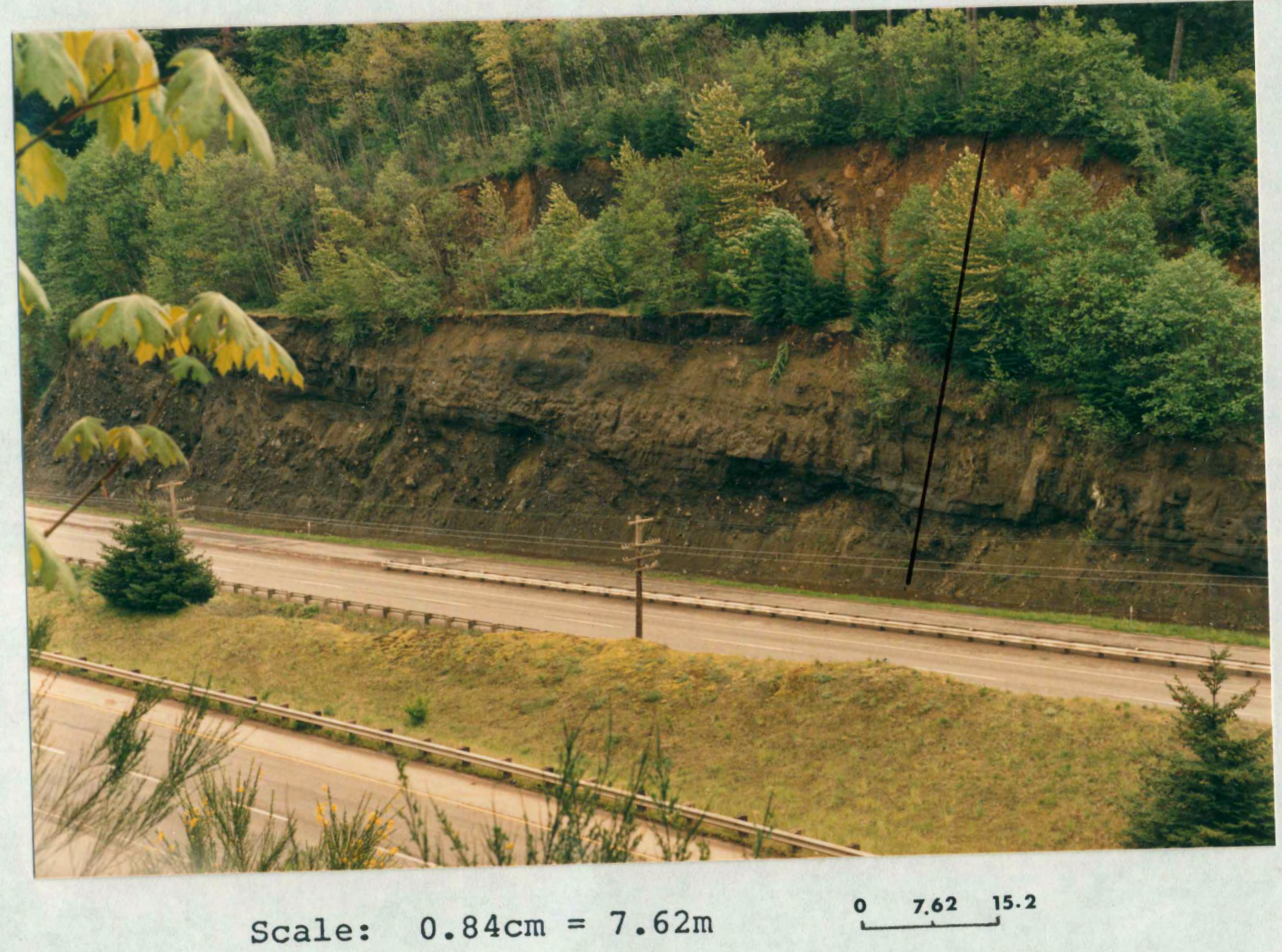

Outcrop east side of Eagle Creek along entrance to I-84.

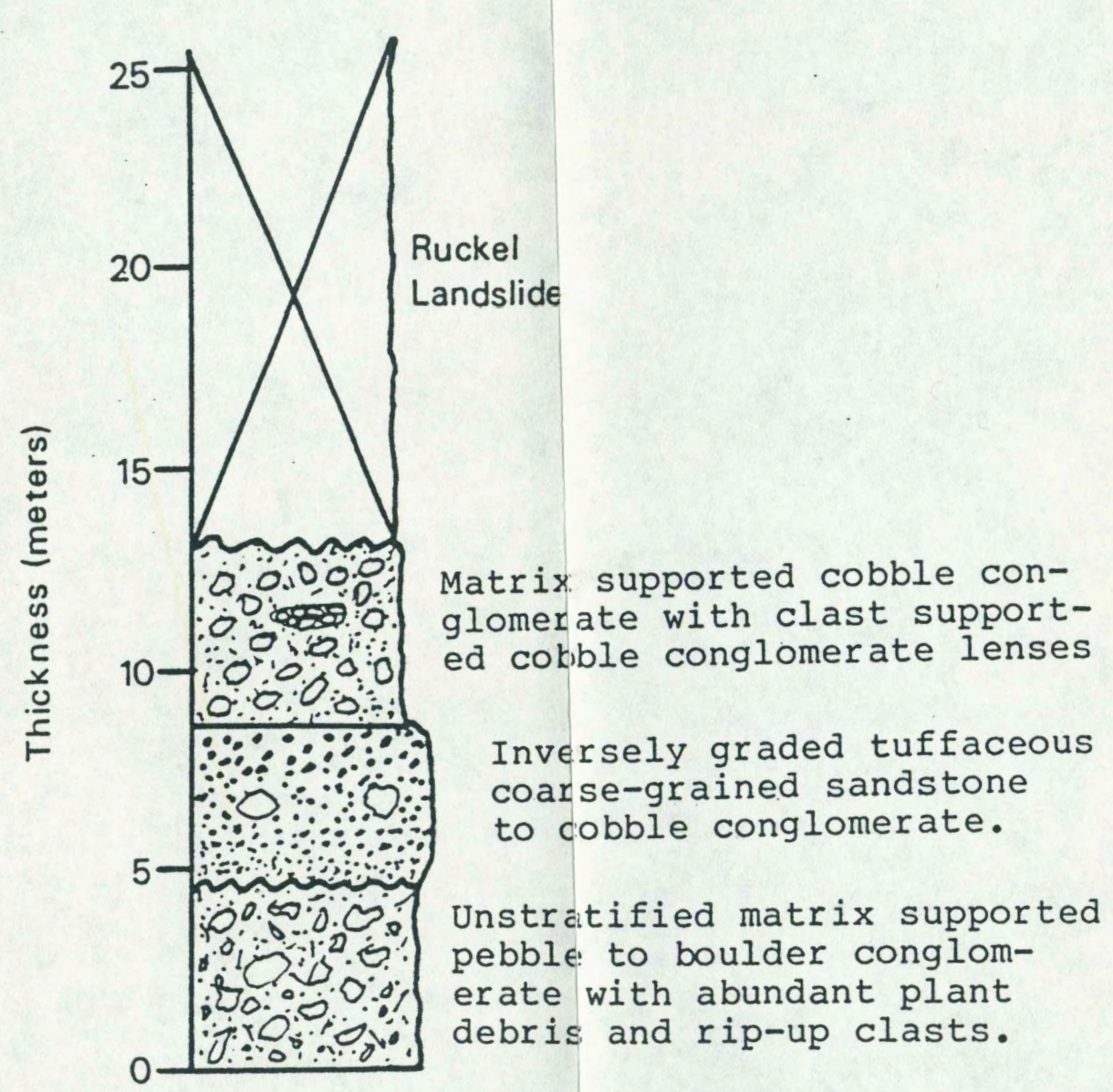

Vertical scale:

$3.38 \mathrm{~cm}=7.6 \mathrm{~m}$ 